\title{
HEAT TRANSFER ANALYSIS \\ OF THE \\ HIGH-LEVEL WASTE CANISTER
}

2 NOVEMBER 1977

\author{
J. M. Bell \\ J. W. Nienberg \\ M. H. Seidman \\ L. C. Fink
}

\author{
Prepared for \\ Rockwell Hanford Operdlions \\ P. 0. Box 800 \\ Richland, Washington \\ Under Contract No. \\ CPFF 627 \\ Prime Contract EY-77-C-06-1030
} This report was prepared as an account of work
sponsored by the United States Government. Neither the United States nor the United States Department of

Energy, nor any of their employees, nor any of their

contractors, subcontrators, or their, nor any of their

any warranty, express or implied, or assumes any lege

liability or responsibility for the accuracy, comple legal

r un

or usefulness of any information, apparatus, product or

process disclosed, or represents that its use would not 


\section{DISCLAIMER}

This report was prepared as an account of work sponsored by an agency of the United States Government. Neither the United States Government nor any agency Thereof, nor any of their employees, makes any warranty, express or implied, or assumes any legal liability or responsibility for the accuracy, completeness, or usefulness of any information, apparatus, product, or process disclosed, or represents that its use would not infringe privately owned rights. Reference herein to any specific commercial product, process, or service by trade name, trademark, manufacturer, or otherwise does not necessarily constitute or imply its endorsement, recommendation, or favoring by the United States Government or any agency thereof. The views and opinions of authors expressed herein do not necessarily state or reflect those of the United States Government or any agency thereof. 


\section{DISCLAIMER}

Portions of this document may be illegible in electronic image products. Images are produced from the best available original document. 


\section{HEAT TRANSFER ANALYSIS \\ OF THE \\ HIGH-LEVEL WASTE CANISTER}

2 NOVEMBER 1977

J. M. Bell, Project Manager

Approved by:

R. K. Plebuch, Manager

System Survivability Department

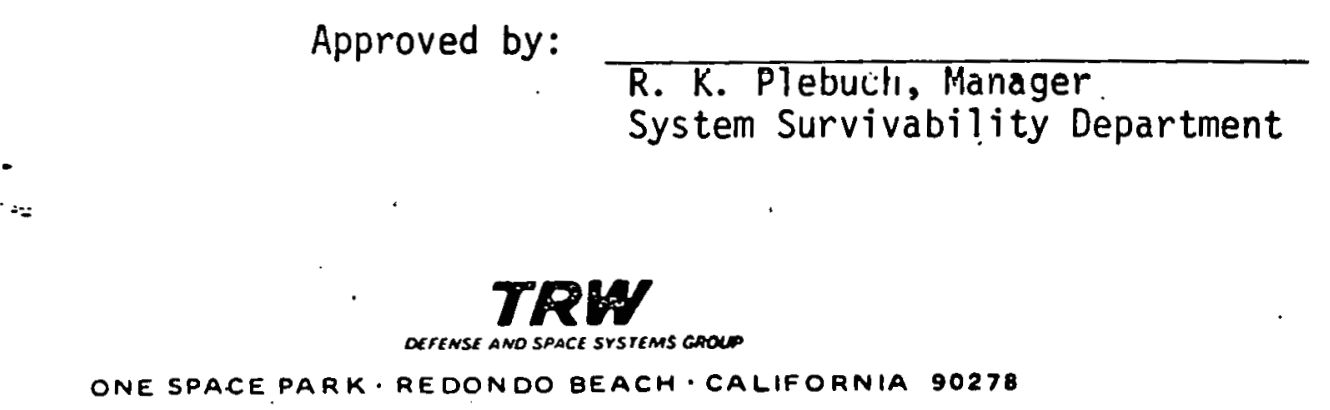




\section{SUMMARY}

This report documents the results of a preliminary, two-month study to determine the design constraints imposed by heat transfer considerations on canisters containing solidified, high-level nuclear waste. The waste is derived from the reprocessing of light water reactor fuel for uranium recycle at 160 days after reactor discharge. The study was conducted for Rockwell Hanford Operations in support of their high-level Waste Canister Enve Tope study.

Candidate solidified waste forms considered in this study are in-can melted borosilicate glass and stabilized calcine. Each canister is assumed to be ten feet long, filled with waste to a height of eight feet, and fabrica ad of 304L stainless steel. Air-and water-cooled.interim storage of the canister at the Fuels Reprocessing Plant (FRP) are considered pr?\% to ultimate storage in deep geologic media at Federal repositories. Candidate repository media are salt, shale and basalt.

Canister design constraints arise because of the need to maintain the waste forms, canisters, and geologic media below certain critical temperatures. Design constraints, in terms of the maximum allowable canister diameter and heat load, are presented for interim storage at the FRP and for ultimate storage at the repositories. For interim storage, these constraints are presented parametrically in terms of: the time since reprocessing (i.e., the waste age) at which the canister is filled and enters interim storage; the type of cooling used during inter illi storage; the temperature constraints that may be imposed; and whether or not the canister is overpacked. For geologic storage it is assumed that the canister is overpacked and enters geolonic storage ten years after reprocessing. Preliminary conclusions, and recommendations for future analyses, are presented. 
TABLE OF CONTENTS

$\underline{\text { Page }}$

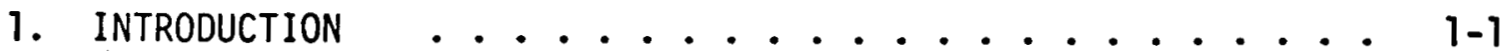

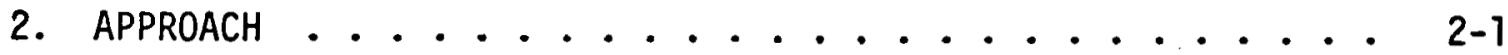

2.1 SCOPE $\ldots \ldots \ldots . \ldots \ldots 2-1$

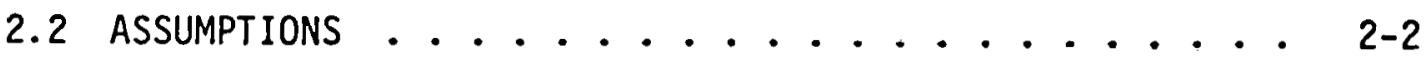

2.2.1 schedule ................ 2-2

2.2.2 Physical Models .......... 2-3

2.2.3 Thermophysical Properties ........ 2-11

2.2.4 Thermal Criteria .......... 2-13

2.2.5 Thermal Models ........... 2-15

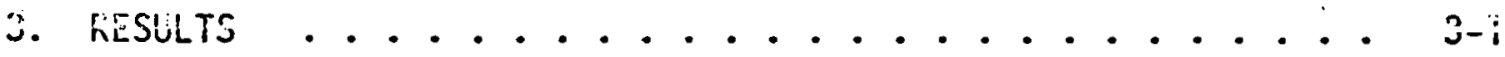

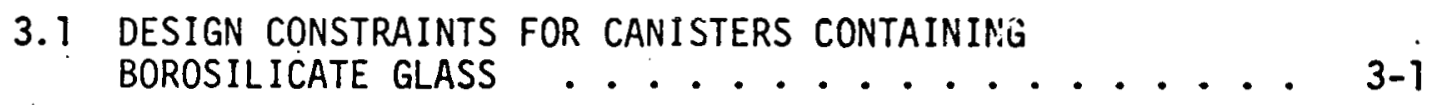

3.1.1 Interim Storage .......... 3-1

3.1 .2 Geologic Storage ......... 3- . 3

3.1 .3 Summary . . . . . . . . . . 3-9

3.2 DESIGN CONSTRAINTS FOR CANISTERS CONTAINING CALCINE . 3 3-11

3.2.1 Interim Storage ........... 3-11

3.2.2 Geologic Storage .............. 3-13

3.2.3 Summary .............. 3-17

3.3 TEMPERATURE HISTORIES $\ldots \ldots \ldots$. . . . . . . . . . .

3.4 SENSITIVITY OF DESIGN CONSTRAINTS . . . . . . 3-22

3.4.1 Waste Source ............. 3-22

3.4 .2 Waste Age............. 3-... 322

3.4.3. Ambient Air Temperature in Interim Storage . . 3-22

3.4.4 Canister Emissivity .......... 3-22

3.4.5 Canister/Overpack Backfill ........ 3-25

3.4.6 Mine Backfill ............ 3-. 36

3.4.7 Canister Temperature Constraint ..... 3-26

3.4.8 Calcine Canister Configuration ....... 3-28

3.4.9 Modeling Approach ........... 3-34 


\section{TABLE OF CONTENTS (Continued)}

Page

4. CONCLUSIONS AND RECOMMENDATIONS. ............... . 4-1

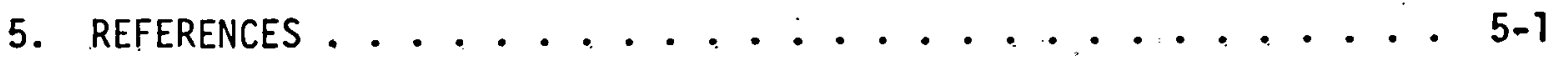

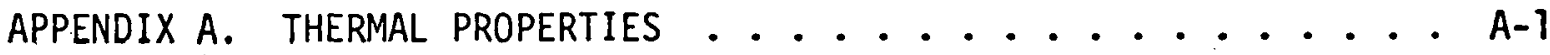

APPENDIX B. BIBLIOGRAPHY ................. B-

APPENDIX C. CANISTER FIN MODEL ............... c 


\section{LIST OF FIGURES}

Page

1-1 Artist's Concept of a Federal Repository ........ 1-1

1-2 Waste Thermal History ............. 1-2

2-1 Fin/Canister Design (Borosilicate Glass Only) ..... 2-4

2-2 Glass-Filled Canister Heat Loading . . . . . . . . 2-4

2-3 Calcine-Filled Canister Heat Loading . . . . . . 2-5

2-4 Water Basin Cooling Concepts ........... 2-6

2-5 Canister/Overpack/Sleeve Configuration for a Repository ... 2-7

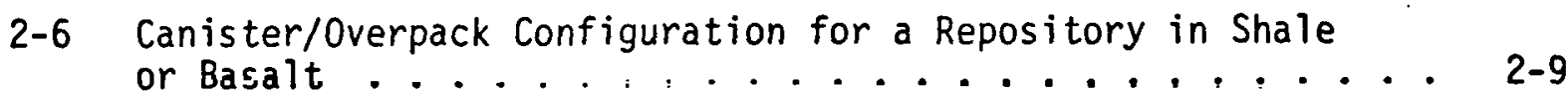

2-7 Mine Layout ............... 2- . . . . . . . . . .

2-8 Thermal Conductivity of Salt........... 2-12

2-3 Canister Matrix Shonin, Approximate Symmetrical Boundary ... 2-18

2-10 Cell Defined for the R-Z Model .......... 2- . . 2-19

2-11 Typical Node and Conductor Configuration in R-Z Model . . . 2-23

2-12 Vertical Cross-Section of Nodalized Cell ........ 2-24

2-13 Cutout From Figure 2-12 Showing Radiation and Convection Modeling of the Room Air Gap........... 2-25

2-14 Vertical Cross-Section of Canister and Surrounding Area Showing Thermal Conductors and Nodes......... 2-27

2-15 Horizontal Cross-Section of Canister Depicting Parallel Heat Flow Paths Through Fin and Waste ........ 2-28

3-1 Design Constraints for Canisters Containing Borosilicate Glass in Water-Cooled Interim Storage ........ 3-2

3-2 Design Constraints for Canisters Containing Borosilicate Glass in Air-Cooled Interim Storage ......... 3-4

3-3 Design Constraints for Canisters Containing Borosilicate Glass Stored in a Salt Repository (10-Year-01d PWR Waste; Canister With Overpack) .............. 3-5

3-4 Design Constraints for Cariisters Containing Borosilicate Glass Stored in a Shale Repository (10-Year-0id PWR Waste; Canister With Overpack) ............. 3-6

3-5 Design Constraints for Canisters Containing Borosilicate Glass in a Basalt Repository (10-Year-01d PWR Waste; Canister With Overpack) ............ 3-7

3-6 Net Mine Area Requirements for Overpacked, Glass-Filled Canisters .................... 3-8 
LIST ar YGURES (Continued)

Page

3-7 Temperature History of an Overpacked, Glass-Filled Canister Following Loss of Water Cooling........... 3-11

3-8 Design Constraints for Canisters Containing Calcine Waste Stored in Water-Cooled Interim Storage ....... 3-12

3-9 Design Constraints for Canisters Containing Calcine Waste Stored in Air-Cooled Interim Storage .......... 3-14

3-10 Design Constraints for Canisters Containing Caicine Stored in a Salt Repository (10-Year-01d PWR Waste; Canister With Overpack ........................ 3-15

3-11 Design Constraints for Canisters Containing Calcine Stored in a Shale Repository (10-Year-0ld PWR Waste; Canister With

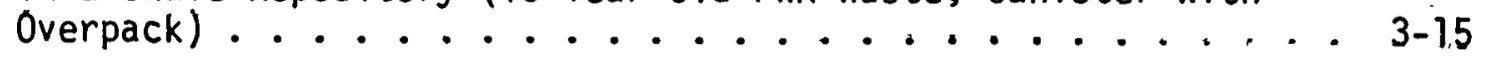

3-12 Design Constraints for Canisters Containing Calcine Waste Stored in a Basalt Repository (10-Year-01d PWR Waste;

Canister With Overpack) .............. 3-16

3-13 Net Mine Area Requirements for Overpacked, Calcine-Filled Canisters ..................... 3-17

3-14 Temperature History in Salt Repository (12-Inch Diameter Canister; Overpacked; Glass Waste) .......... 3-19

3-15 Temperature History in a Shale Repository (12-Inch Diameter Canister; Overpacked; Glass Waste) .......... 3-20

3-16 Temperature History in a Basalt Repository (12-Inch Diameter Canister; Overpacked; Glass Waste) .......... 3-21

3-17 Effect of Waste Source on Design Constraints for Canisters Containing Glass in a Salt Repository (10-Year-01d Waste; Canister With Overpack)............. 3-23

3-18 Effect of Waste Age on Design Constraints for Canisters Containing Glass in a Salt Repository (Canister With Overpack) 3-24

3-19 Effect of Overpack Backfill on the Allowable Diameter and Heat Loading of Glass-Filled Canisters in Water-Cooled Interim Storage ................ 3-25

3-20 Effect of Backfill on Design Constraints for Canisters Containing Glass in a Basalt Repository (10-Year-01d PWR Waste; Canister With Overpack)

3-21 Canister Diameter Constraint Introduced by Limiting Canister Temperature to $350^{\circ} \mathrm{C}$ (GTass-Salt, 10-Year-01d PWR Waste; Canister With Overpack)............... 3-29

3-22 Canister Diameter Constraint Introduced by Limiting Canister Temperature to $350^{\circ} \mathrm{C}$ (Glass-Shale, 10-Year-01d PWR Waste; Canister With Overpack) ............. 3-30 


\section{LIST OF FIGURES (Continued)}

Page

3-23 Canister Diameter Constraint Introduced by Limiting Canister Temperature to $350^{\circ} \mathrm{C}$ (Glass-Basalt, 10-Year-01d PWR Waste; Canister With Overpack)............... 3-31

3-24 Canister Diameter Constraint Introduced by Limiting Canister Temperature to $350^{\circ} \mathrm{C}$ (Calcine-Salt; 10-Year-01d PWR Waste; Canister With Overpack)................ 3-32

3-25 Canister Diameter Constraint Introduced by Limiting Canister Temperature to $350^{\circ} \mathrm{C}$ (Calcine-Shale; 10-Year-01d PWR Waste; Canister With Overpack)................ 3-33

3-26 Canister Diameter Constraint Introduced by Limiting Canister. Temperature to $350^{\circ} \mathrm{C}$ (Calcine-Basalt; 10-Year-0ld PWR Waste; Canister With Overpack) . . . . . . . . . . . . . 3-33

3-27 Effect of Annular Canister on Allowable Diameter and Heat Loading of Calcine-Filled Canisters in Water-Cooled Interin Storage (PWR Waste)............... 3-35

3-28 Effect of Annular Canister on Allowable Viameter and Heat Loading of Calcine-Filled Canisters in Air-Cooled Interim Storage (PWR Waste)................ 3-36

3-29 Diameters for Calcine-Filled Annular Canisters in a Salt Repository (10-Year-01d PWR Waste; Canister With Overpack) . 3-37

3-30 Diameters for Calcine-Filled Annular Canisters in a Shale Repository (10-Year-01d PWR Waste; Canister With Overpack) . 3-37

3-31 Comparison of Results for Calcine-Filled Canisters in a Salt Repository (10-Year-01d PWR Waste) . . . . . . . 3-38

A-1 Borosilicate Glass Conductivity . . . . . . . . . . A-2

A-2 Geologic Formation Temperatures Prior to Burial of Waste . . A-4

A-3 Shale Thermal Conductivity . . . . . . . . . . A-7

A-4 Basalt Thermal Conductivity (Fully Compacted) . . . . . . A-8

A-5 Basalt Thermal Conductivity (Crushed) . . . . . . . . A-9

C-1 Two-Dimensional Actual Waste/Fin Model .......... C-2

C-2 Comparison of Steady-State Solutions for the "Smeared" and "Actual" fin models................. C-4 


\section{LIST OF TABLES}

Page

3-1 Comparison of Areal Power Densities . . . . . . . . 3-40

4-1 Design Constraints for Canisters With PWR Waste in Borosilicate Glass .................... 4-2

4-2 Design Constraints for Canisters With PWR Waste in Calcine . 4 4-3 


\section{INTRODUCTION}

Reprocessing of irradiated Light-Water Reactor fuel elements to recover uranium and plutonium, using the solvent extraction process, will generate highly radioactive (i.e., high-level) liquid wastes. Title 10 of the Code of Federal Regulations, Part 50, (10CFR50) requires that:

- A Fuel Reprocessing Plant's inventory of high-level liquid radioactive wastes must be limited to that produced in the prior five years;

- High-level liquid radioactive wastes must be converted to a dry solid and placed in a sealed container, or canister, prior to transfer to a Federal repository; and

- All high-level wastes must be transferred to a Federal repository no later than ten years following reprocessing.

In early 1976 the U.S. Energy Research and Development Administration expanded the nuclear waste management effort and created the National Waste Terminal Storage (NWTS) program. Responsibility for management of this program is with the Office of Waste Isolation (OWI) of the Union Carbide Corporation - Nuclear Division. The principal objective of the NWTS program is to provide repository facilities, such as that shown in Figure $1-1$, in various deep geologic formations at multiple locations in the

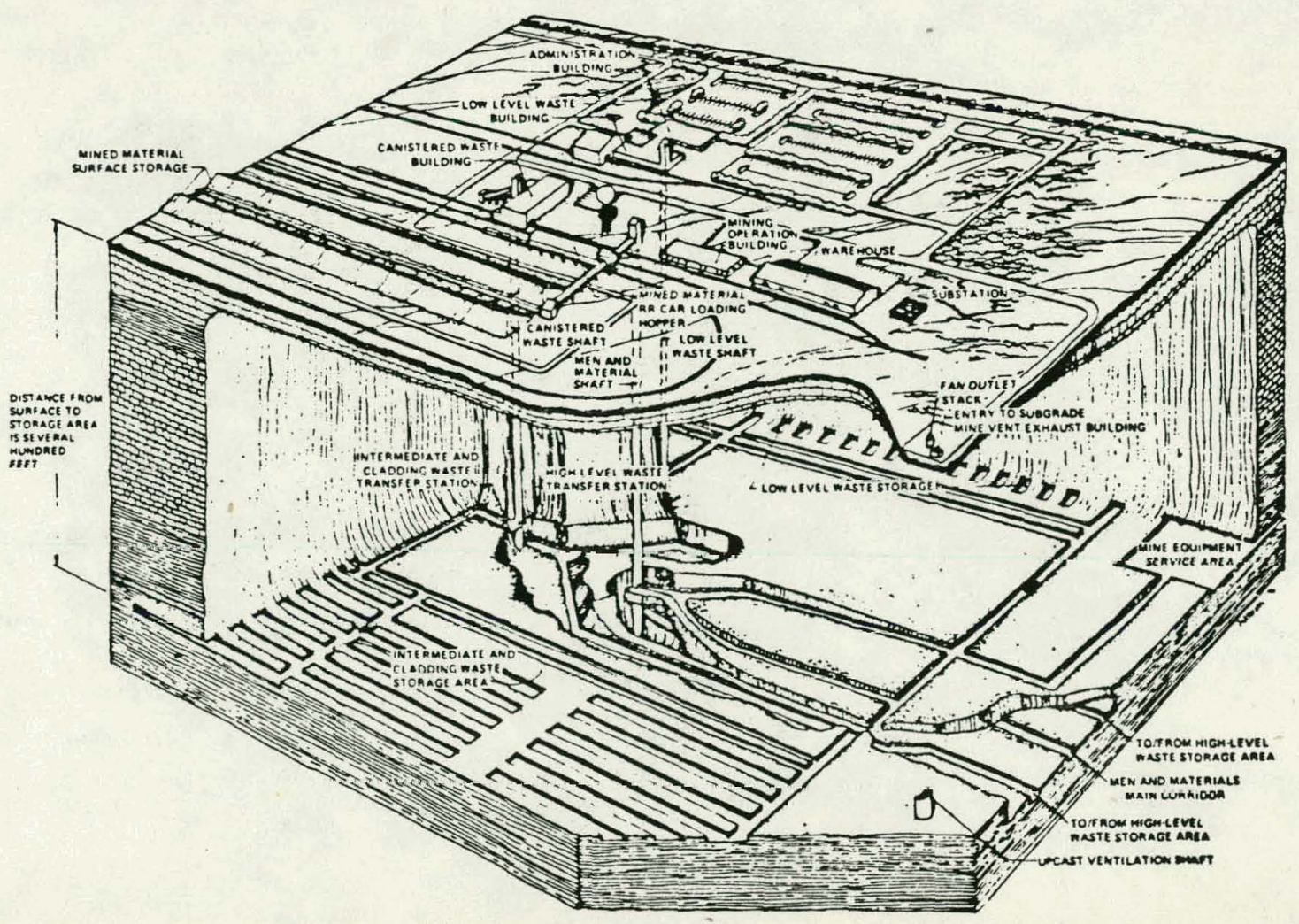

Figure 1-1. ARTIST'S CONCEPT OF A FEDERAL REPOSITORY (REFERENCE 1) 
United States which will safely dispose of the commercial radioactive waste which must be delivered to a Federal repository for terminal storage.

Design criteria for the high-level waste canister are not defined in 10CFR50. A definitive canister design is required in order that firm plans,' designs, cost evaluations, etc. can be prepared for reprocessing and disposal facilities and operations. Toward that end, OWI initiated the highlevel Waste Canister Envelope Study at the Atrantic Richfield Hanford Company (now the Rockwell Hanford Operations of the Rockwell International Corporation). The objective of this study is to establish canister design criteria and designs to ensure that the canisters will be compatible with all handling equipment and environments, from the time of waste solidification until emplacement in a Federal repository, including possible retrievable operation during a fixed period after emplacement.

The power density of the waste at the time of reprocessing can be on the order of 10 watts per cubic inch. Ás snown in Figure $i-\bar{z}$ for a typica $i$

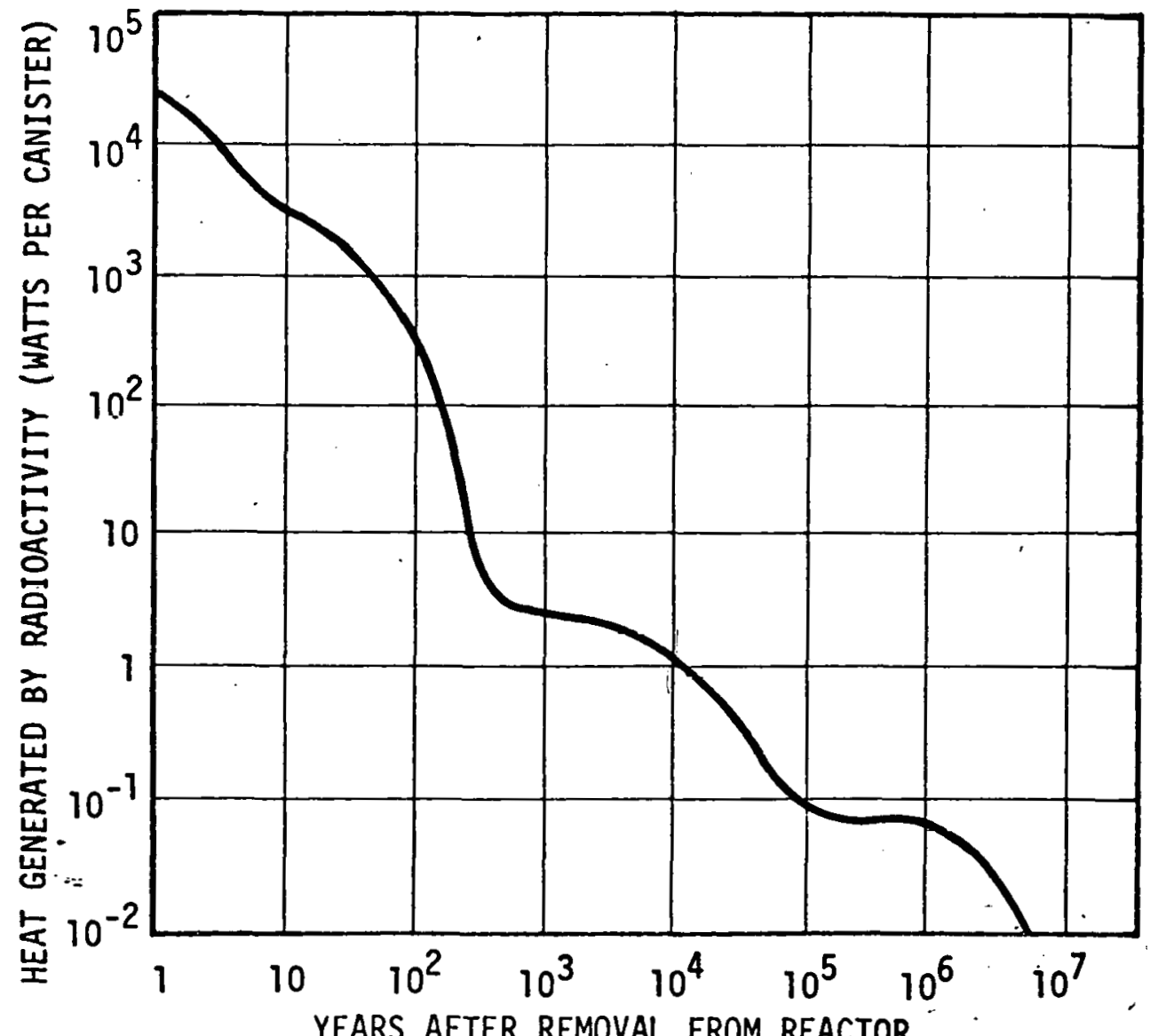

FIGURE 1-2. WASTE THERMAL HISTORY 
high-level waste canister, the isotopes in the high-level waste decays with time to approximately 5 percent after 10 years and to 0.5 .percent after 100 years. Thus, development of design criteria for high-level waste canisters must consider both the time-dependent power and the temperature limits which have been prescribed for the candidate waste forms, canister materials and geologic storage media.

The TRW Defense and Space Systems Group was selected by Rockwell to support the high-level Waste Canister Envelope Study by conducting an analysis to define the constraints imposed on the canister designs by heat transfer considerations. Rockwell technical direction was provided by Dr. E. L. Moore. The objective was to determine acceptable canister geometries and heat loads for the range of candidate waste forms, canister configurations, interim storage techniques and repository geologic media. The approach thit was adopted was to scqucntia??y sxamina the canisten's complete ? ife cycle, revieiw past heat transfer studies of canister life-cycle phases that have been conducted by other agencies, identify gaps in existing information and fill these gaps with computer-aided heat transfer analyses.

Due in part to the short period of time allotted to complete this study, it was necessary to assume that: canister geometries would be limited to a cylindrical shape; and one- and two-dimensional thermal models would provide an adequate degree of accuracy. The primary output of this study, then, is the definition of the maximum allowabie canister diameters for the range of candidate waste forms, canister configurations, interim storage techniques and repository media.

Section 2 of this report describes the study scope and assumptions. Section 3 presents the results obtained for the baseline cases considered and examines possible alternate cases. Conclusions and recommendations are contained in Section 4. The detailed thermophysical properties used. in this study, a bibliography of the reports that were reviewed, and a verification of the thermal model used for the glass-filled canister, with fins, are documented in the appendices. 


\section{2. $A P P R O A C H$}

The overall objective of the study reported herein was to determine the acceptable geometries and heat loads of high-level radioactive waste canisters based on heat transfer limitations. The general approach adopted to meet this objective consisted of:

- Reviewing the literature to compile applicable study results.

- As necessary, supplementing past study results with heat transfer analyses.

With certain exceptions which are noted in the appropriate sections, the literature reviewed (see Appendix B, Bibliography) indicated that past thermal analyses had been rondur.ter with groundrules and assumptions which were ufficiently different that the results could not be readily extrapolated to the groundrules and assumptions adopted in this study. Therefore, these thema? anz? yses ue:e retterated in the prosant study. A detailed discussion of the study scope and assumptions is presented in the following paragraphs.

\subsection{SCOPE}

For heat transfer considerations, the canister life cycle was assumed to consist of the following principai phases:

- Waste Solidification and Canister Filling, with the following two options: in-can melting to produce a borosilicate glass-type waste form, or fluidized-bed calcination plus stabilization to produce a calcine-type waste form.

- Interim Storage of the canisters at the Fuels Reprocessing Plant (FRP) in either air or water.

- Transportation of the canisters from the FRP to the Federal repository, in shipping casks designed in accordance with DOT and NRC requi rements.

- Geologic Storage, including receipt at the repository and al

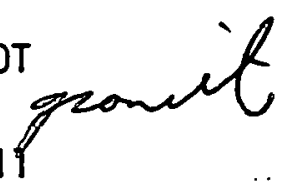
operations involving empiacement in either a salt \& shate or basalt medium and residence in the medium for an indefinite period of time. This phase includes the potential for retrieval for a limited time after emplacement.

The waste solidification and canister filling phase was not addressed in this study because it is the subject of intensive treatment by the agencies responsible for development of the waste forms (e.g., Battelle Pacific Northwest Laboratories, BPNL, in the case of borosilicate glass). 
Similar'y, transportation phase was not treated here because the design coisitraints imposed by heat transfer considerations during transportation are being assessed in a separate, Rockwell-funded study. Therefore, the present study focused on the design constraints imposed by heat transfer considerations during the interim storage and geologic storage phases of the canister life cycle.

\subsection{ASSUMPTIONS}

This section describes the assumptions that were made in modeling the interim storage and geologic isolation phases of the high-level waste canister life cycle. These assumptions are related to: the schedule; the canister, overpack and sleeve designs; the design of the Federal repository; the thermophysical properties of the materials involved; and the tempericure constiaints that were imposed. Although certain design and operational aspects involved in the proposed management of high level wastes have not, as yet, been definitized the assumptions made here are thought to be consistent with current planning.

\subsubsection{Schedule}

The canister design constraints are directly affected by the time at which certain operations occur, specifically: the time after reactor discharge at which reprocessing occurs; the time at which the canisters containing solidified, high-level waste first enter interim storage at the FRP; and the time at which the canisters are emplaced in the Federal repository.

After the spent fuel is removed from the reactor it is stored for several months to allow the short-half-lived isotopes, such as iodine 131 , to decay. For this study, an elapsed time from reactor discharge to fuel reprocessing of 160 days was assumed (Reference 2).

The groundrules established by 10CFR50 are that high-level liguid wastes must be solidified and placed in sealed canisters within 5 years after reprocessing and transferred to a Federal repository within 10 years. Theoretically, solidified wastes could reach the repository very. soon after reprocessing. However, due to the rapid thermal decay during the first 10 years, and the likelihood of there being an economic incentive to delay transfer for the maximum possible time, it is more likely 
that the waste will be approximately 10 years old when transferred to the repository. Thus, the baseline case considered in this study consisted of initial placement of canisters into interim storage at any time during the first 5 years after reprocessing, storage until the waste is 10 years $01 d$, followed by transfer to, and emplacement in, the Federal repository.

\subsubsection{Physical Models}

The solidified high-level waste was assumed to have been generated as the result of the reprocessing of spent fuel from a light water reactor (LWR). Uranium-only recycle was assumed. Emphasis was placed on waste from a pressurized water reactor (PWR) because of the higher. inherent power per unit volume. Appendix A gives the details of the initial fuel enrichment and burnup assumed, and the resultant thermal history following reprocessing at 160 days out..of-reactor.

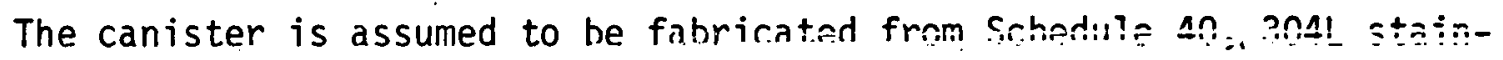
less steel pipe. The canister is 10 feet 1sng. Although not treated in this study, the results for a canister with length greater than, or less than, 10 feet are expected to be identical for interim storage, and only sightly different for geologic storage. The canister is filled with waste to a height of. 8 feet. Canister diameter is a variable whose maximum is constrained by the various temperature limits.

A canister containing borosilicate glass which has been formed by in-can melting contains internal fins of $304 \mathrm{~L}$ stainless steel. Although the function of these fins is to conduct heat into the waste during incan melting, they are also effective in conducting heat away from the centerline during interim storage and geologic storage. BPNL is investigating a variety of fin configurations. The eight-fin design shown in Figure 2-1 is a typical BPNL design for a 12-inch-diameter canister (Reference 3 ). This fin configuration, with the length. determined by the canister radius, was used in this study. Because of the assumption of constant fin thickness the effect of these fins on the glass centerline temperature decreases with increasing radius. Internal fins were not included for canisters containing calcine. Figures 2-2 and 2-3 show the resultant heat loading for glass- and calcine-filled canisters, respectively. 


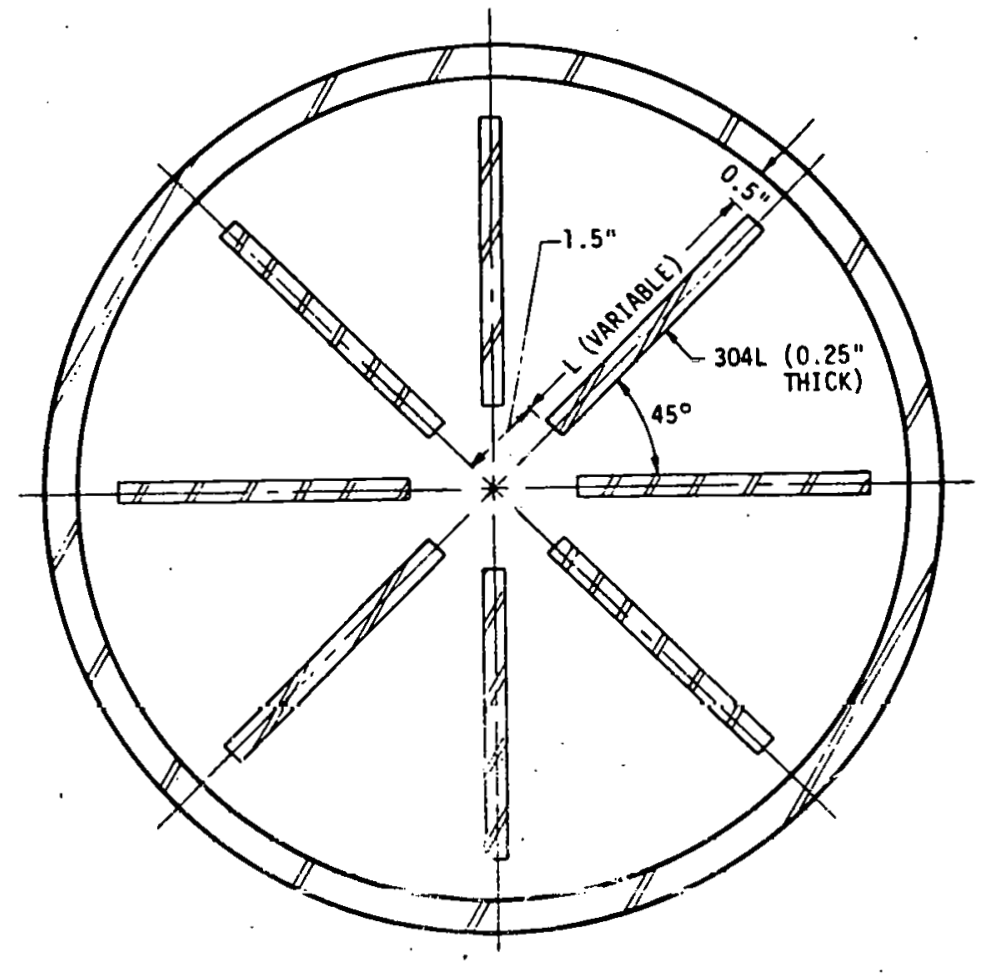

FIGURE 2-1. FIN/CANISTER DESIGIN.(BOROSILICATE GLASS ONLY)

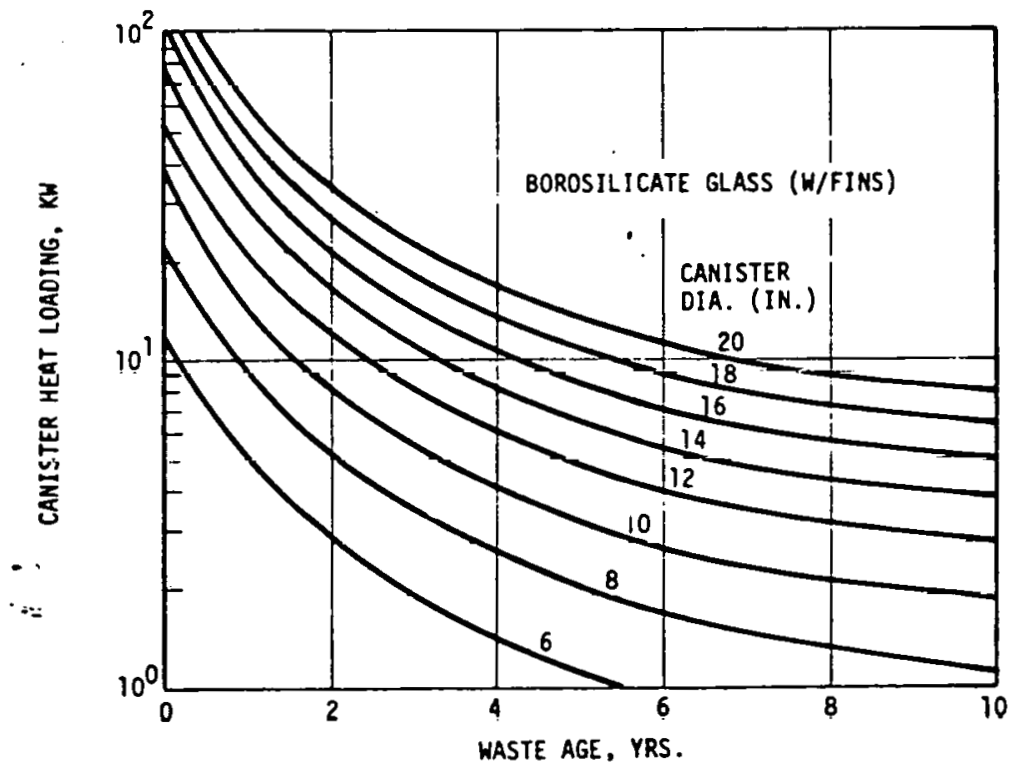

FIGURE 2-2. GLASS-FILLED CANISTER HEAT LOADING

$$
\text { 2-4 }
$$




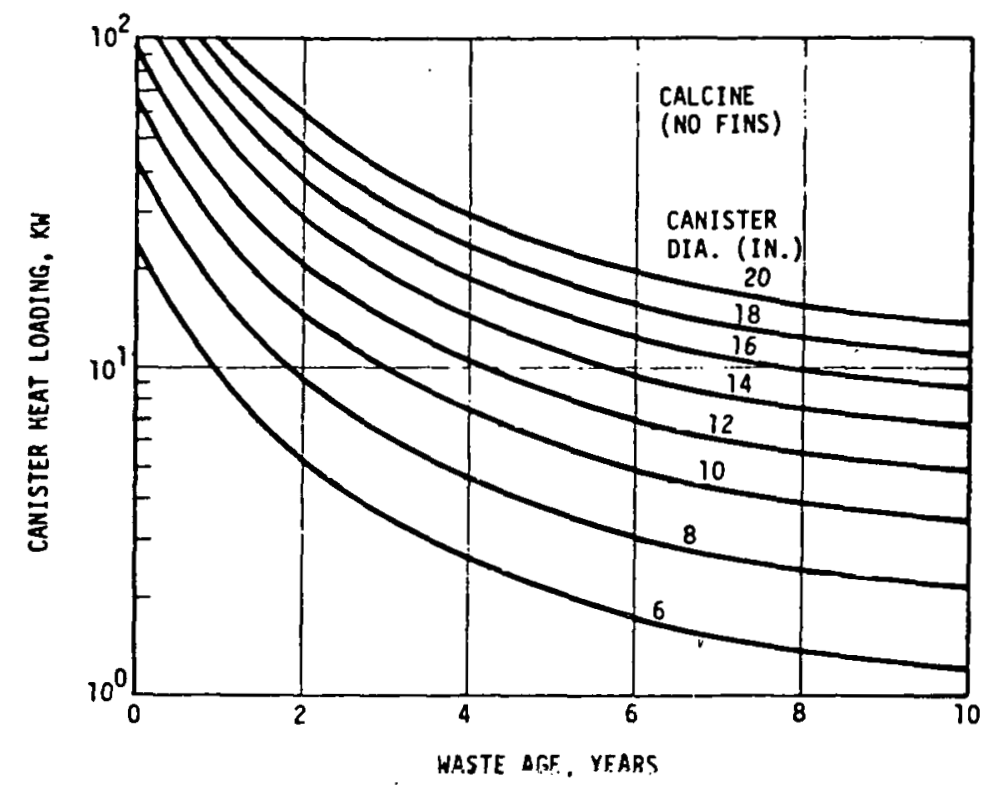

FIGURE 2-3. CALCINE-FILLEU CAINISTER HEAT LOADING

A canister nverpark, constructed of carbon steel, is assumed to be optional during interim storage in air or water, but mandatory during storage in the Federal repository (Reference 2).

Two modes of inteikm storage were investigated: air-cooled and watercooled. In air, the canisters are assumed to be oriented vertically and to be cooled only by free convection and radiation: no forced air cooling was included. In water, the canisters are stored in basins and water with a bulk temperature of $49^{\circ} \mathrm{C}$ is circulated around the canisters. Figure 2-4 (Reference 4) shows the water basin cooling concept. The detailed design is seen to depend on whether or not the canisters are overpacked.

Due to mine stability and hole closure considerations, a salt repository requires a sleeve to be inserted into the hole bored into the floor for canister emplacement. Any remaining gap between the sleeve and the bure hole is backfilled with crushed salt. It is expected (Reference 5) that the crushed salt will become compacted and assume the thermophysical properties of dense salt within 20 years after emplacement. In this study the backfilled annulus of crushed salt was assumied to always have the properties of dense salt. A removable concrete plug rests on the overpack and acts as a radiation shield. Figure 2-5 shows the dimensions of the canister/overpack/sleeve system for a repository in salt. Wall thicknesses and gap dimensions are consistent with Reference 1. 


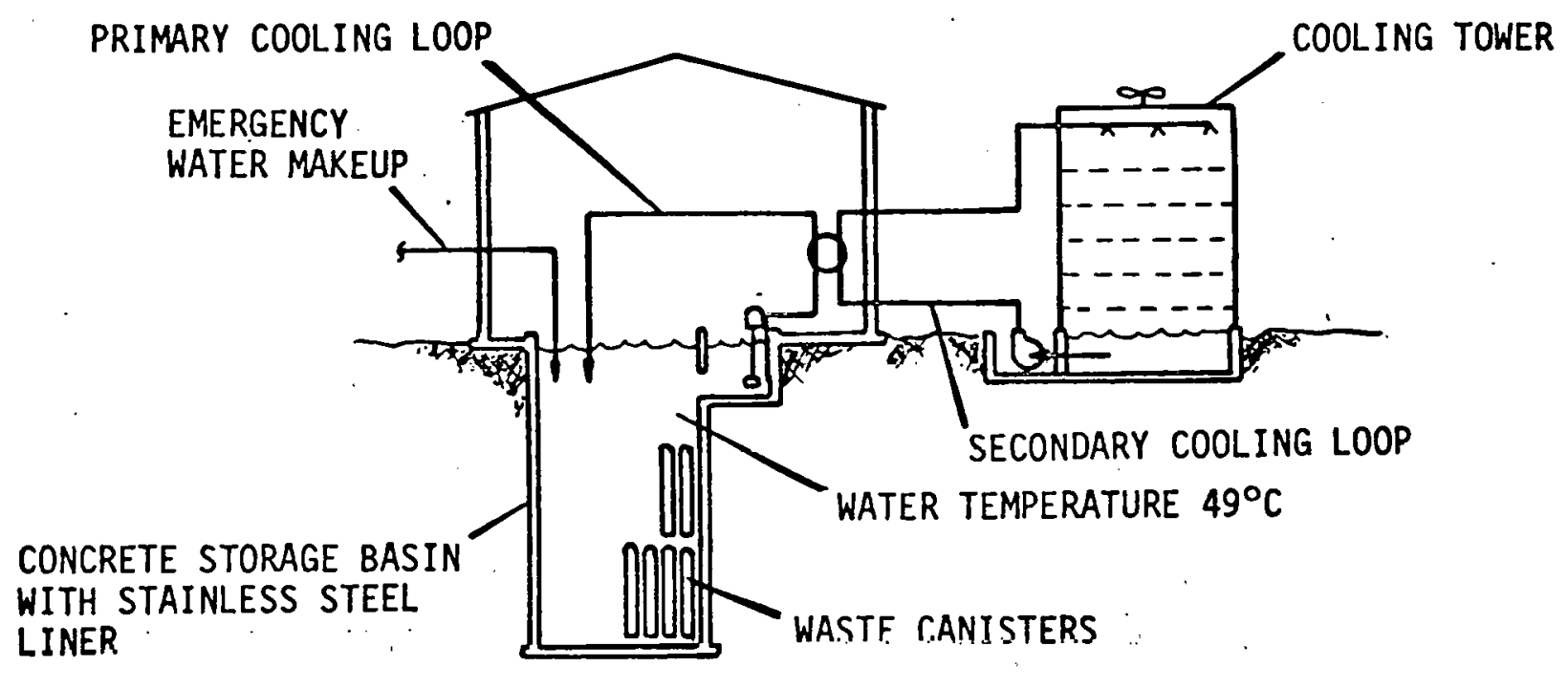

(A.) CAANISTERS WITTHOUT OVERPACKS

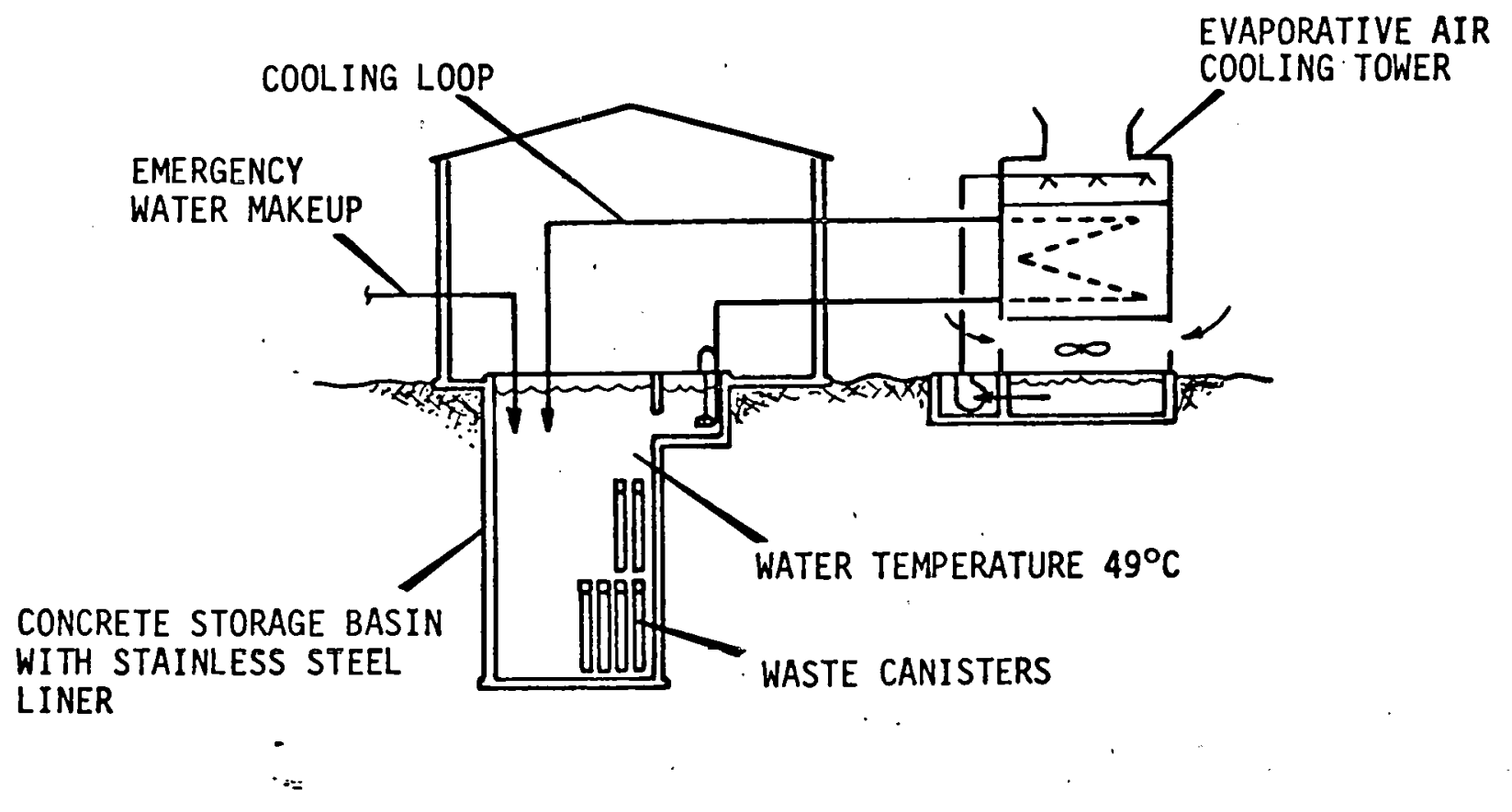

(B) CANISTERS WITH OVERPACKS

FIGURE 2-4. WATER BASIN COOLING CONCEPTS 


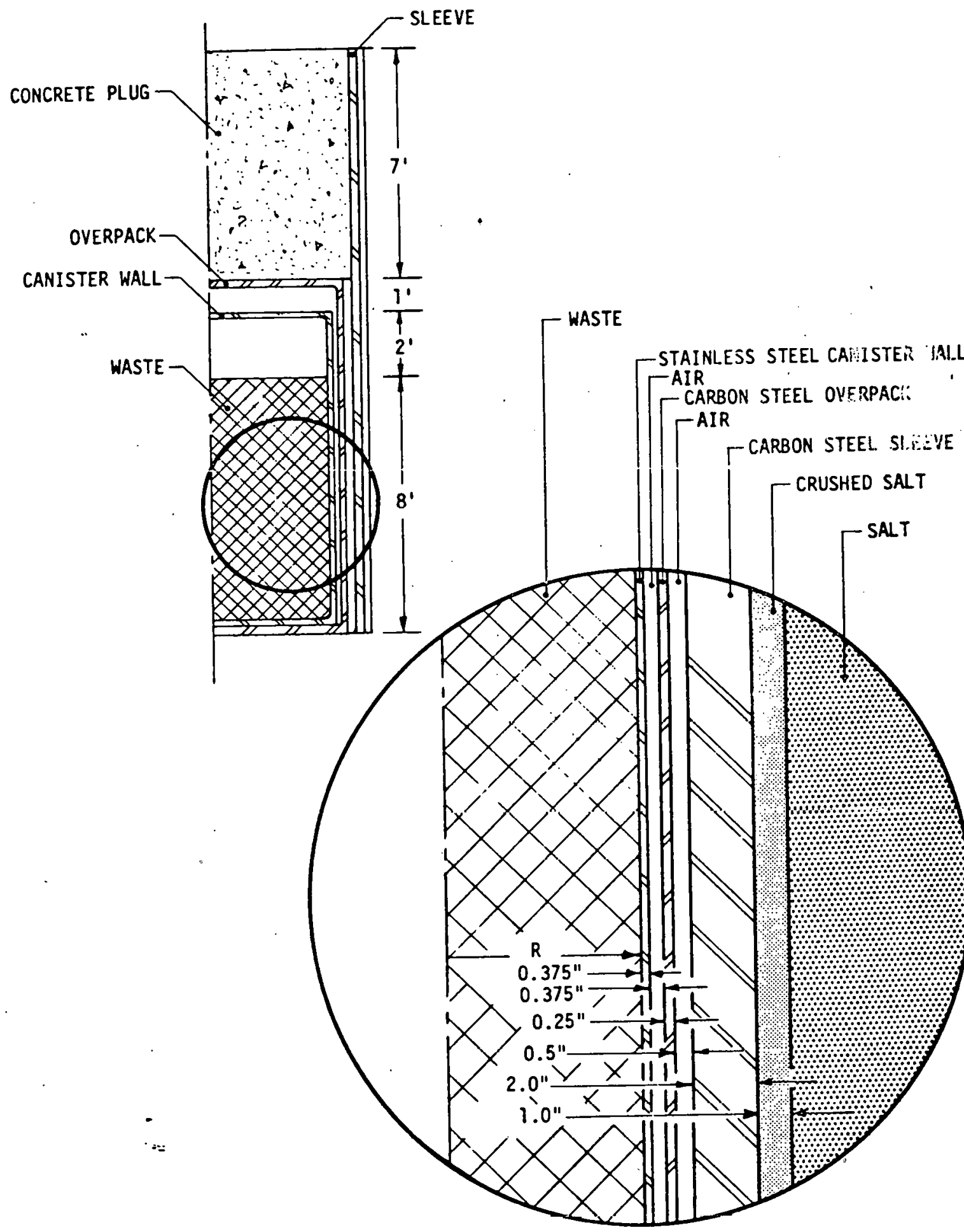

FIGURE 2-5, CANISTER/OVERPACK/SLEEVE CONFIGURATION FOR A REPOSITORY IN SALT . 
It was assined that, because of their stability relative to salt, a repository located in shale or basalt would not require a-sleeve. In shale and basalt the canister is placed directly in a hole bored in the floor and the annular gap is backfilled with crushed material from the mine. This configuration is shown in Figure 2-6."

Canisters will be emplaced in rooms at a depth of 2000 feet (Reference 1) below the surface of the earth. Each room is assumed to be 15 feet high (Reference 6). As described in Section 2.2.4, the twodimensional thermal model which was selected to analyze canister temperature histories necessarily neglected the sides of the room, or pillars, as potential paths for heat conduction. The physical arrangement which the thermal model represents is one of the center-most canisters in a room containing several rows of canisters. The unit cell around each canister can thus be represented by a long, cylindrical core which is

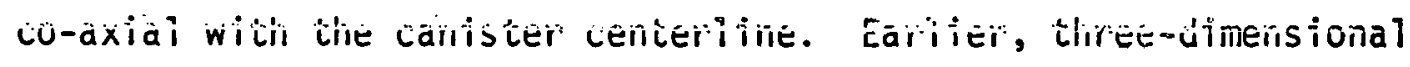
studies (Reference 5) have shown an advantage for narrow rooms with a single row of canisters. This advantage was probably due, in part, to the proximity of the pillars to the canisters and the resultant paths for increased heat conduction away from. the room. Therefore, the results obtained here for a repository located in salt are probably conservative (i.e., the calculated diameters are smaller than if a three-dimensional model had been used). However, for shale and basalt no definitive work has heen performed in defining the optimum room width and canister layout. It is expected that larger rooms can be mined in shale and basalt because of their relative stability. Therefore, the results obtained here for shale and basalt may be more representative than the results obtained for salt.

Forced air circulation will probably he utilized to maintain the floor temperature at an acceptable level during the time that a room is being filled with canisters, in order that personnel and equipment can work within the room. After a room is filled with canisters it will remain open until the end of the retrievability period, during which time room air circulation may or may not be utilized. The retrievability period may be as short as five years for a repository in salt (Reference 7). The effect of air circulation during the retrievability period is examined in References 5 and 8. In Reference 8, for example, it is shown that 


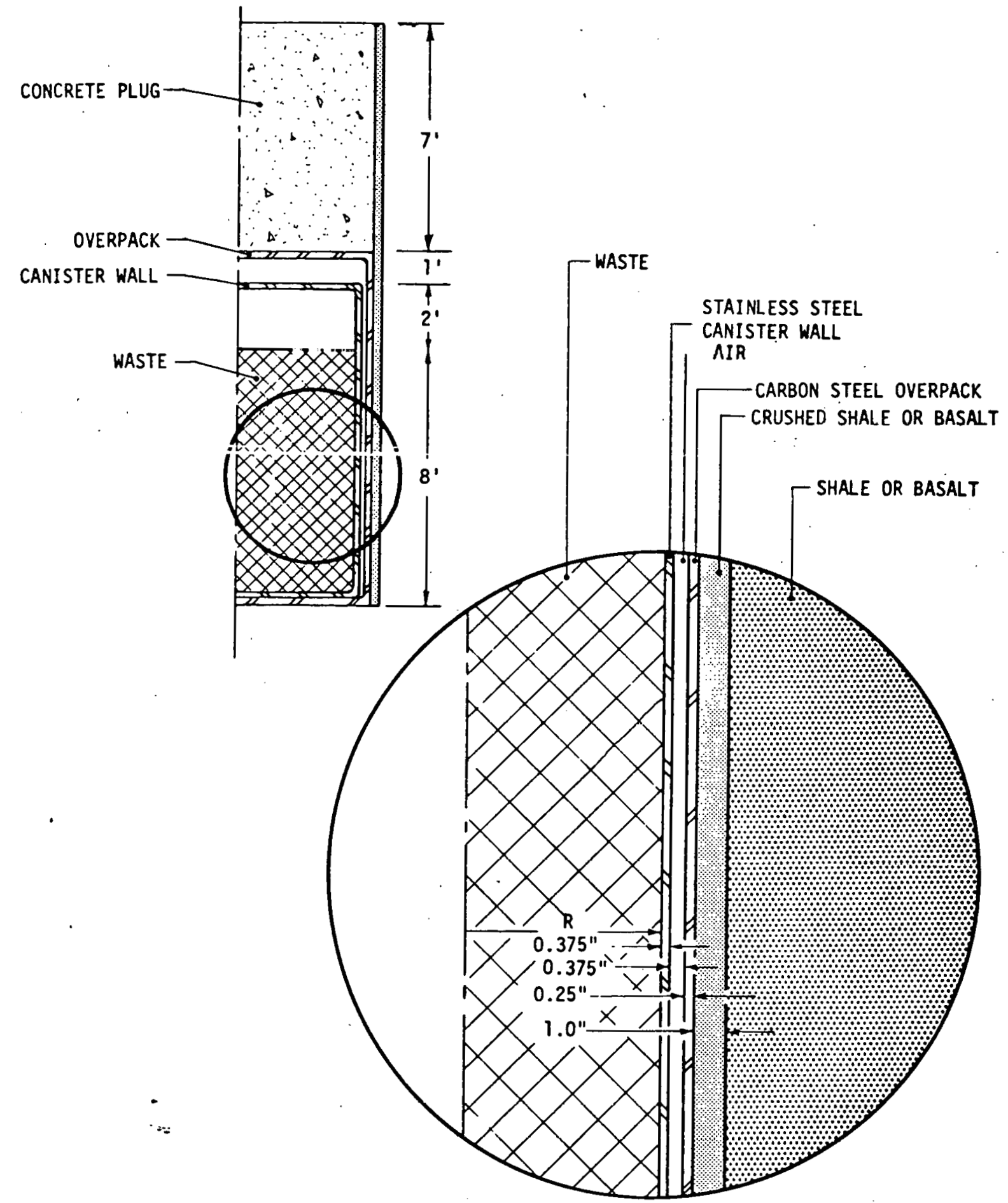

FIGURE 2-6. CANISTER/OVERPACK CONFIGURATION FOR A REPOSITORY IN SHALE OR BASALT 
approximately 65 percent of the total heat generated in the first five years after emplacement can be removed by the circulating air.

Forced air circulation was not considered in this study. It was conservatively assumed that, immediately after canister emplacement, the room is backfilled with crushed sait, shale or basalt to a height of 70 percent (Reference 6) of the room height, thus creating an air gap between the ceiling and the backfill. The air in this gap is assumed quiescent (i.e., no forced air circulation).

The actual stratigraphy of the geologic media above and below the room will vary from one type of formation to another. Some earlier wonk (Reference 5) has addressed the actual stratigraphy for a known location (Project Salt Vault). Because it may not be possible to derive a generalized stratigraphic model for each type of repository medium considered, and hecause surh far-field stratigraphic variations are expected to ha:le only a small influence on canister thermal response, the medium in each case was assumed to extend uniformly to the ground surface and to a depth of 10,000 feet below the mine. Figure 2-7 summarizes the mine layout assumed here.

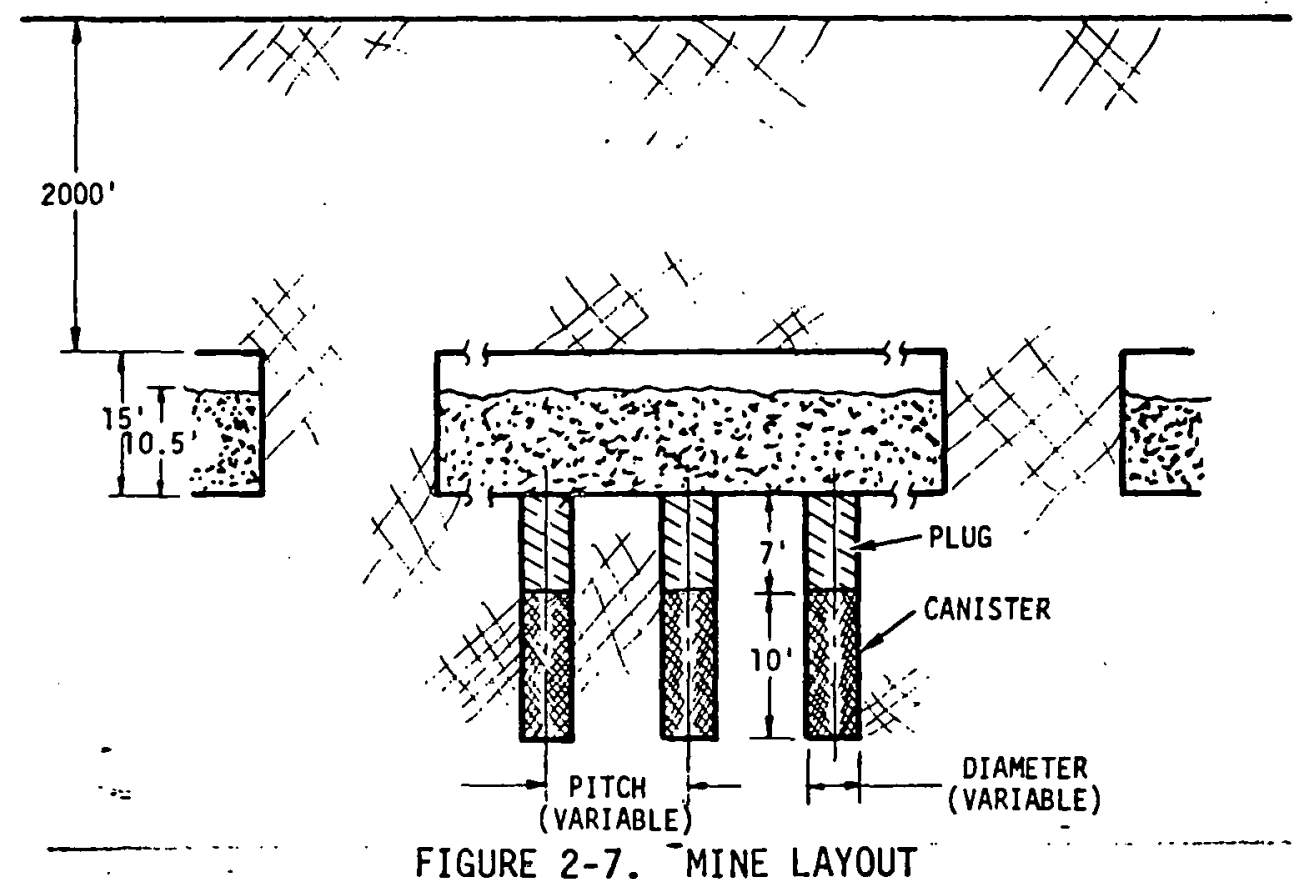

FIGURE 2-7. "MINE LAYOUT

The shale formation in which a repository may be located is likely to be stratified and have anisotropic properties. For this study it was assumed that the strata are horizontal. 


\subsubsection{Thermophysical Properties}

The thermophysical properties of each of the waste forms, metallic members and geologic media that were addressed in this study are presented in Appendix A. Temperature-dependent properties were used for a majority of the materials. Appendix $A$ is self-explanatory, for the most part; however, some comments are pertinent.

As shown, the borosilicate glass thermal conductivity values used in this study are somewhat lower than have been used previously. However, because the baseline case in this study assumes the glass to incorporate fins, changing the glass conductivity has little effect on the results obtained here. Conversely, if the fins were to be deleted a larger effect on the results would be incurred by changing the glass conductivity.

The thermophysical properties of pure salt (i.e., $\mathrm{NaCl}$, or halite) have been well characterized. Previous studies (References $b$ and 6 ) have used the values reported by Birch and Clark (Reference 9) and analytical results based on these values have shown good agreement with experimental resuits at Lyons, Kansas (Reference 10). However, salt properties may vary from formation to formation, and even from one location in a formation to another, depending on the amount of impurities present. Figure 2-8 shows, for example, the variation in salt thermal conductivity from various data sources.

Whereas salt is reasonably well characterized, there is a paucity of data for shale and basalt. Shale is known to be anisotropicand have a temperature-dependent thermal conductivity. As explained in Appendix A, it was necessary to approximate, based on little available data, the thermal conductivity values in the parallel and vertical directions. Additionally, Reference 13 describes the results of shale heating tests in which endothermic reactions, caused by the presence of a Kaolinite mineral impurity, were observed. Such reactions were not accounted for in the heat. transfer models in this study.

As with shale, few thermal conductivity data points were found for basalt as a function of temperature and it was necessary to interpolate the available data. For both shale and basalt the thermophysical properties will vary with the water content, which again may vary from site to site. 


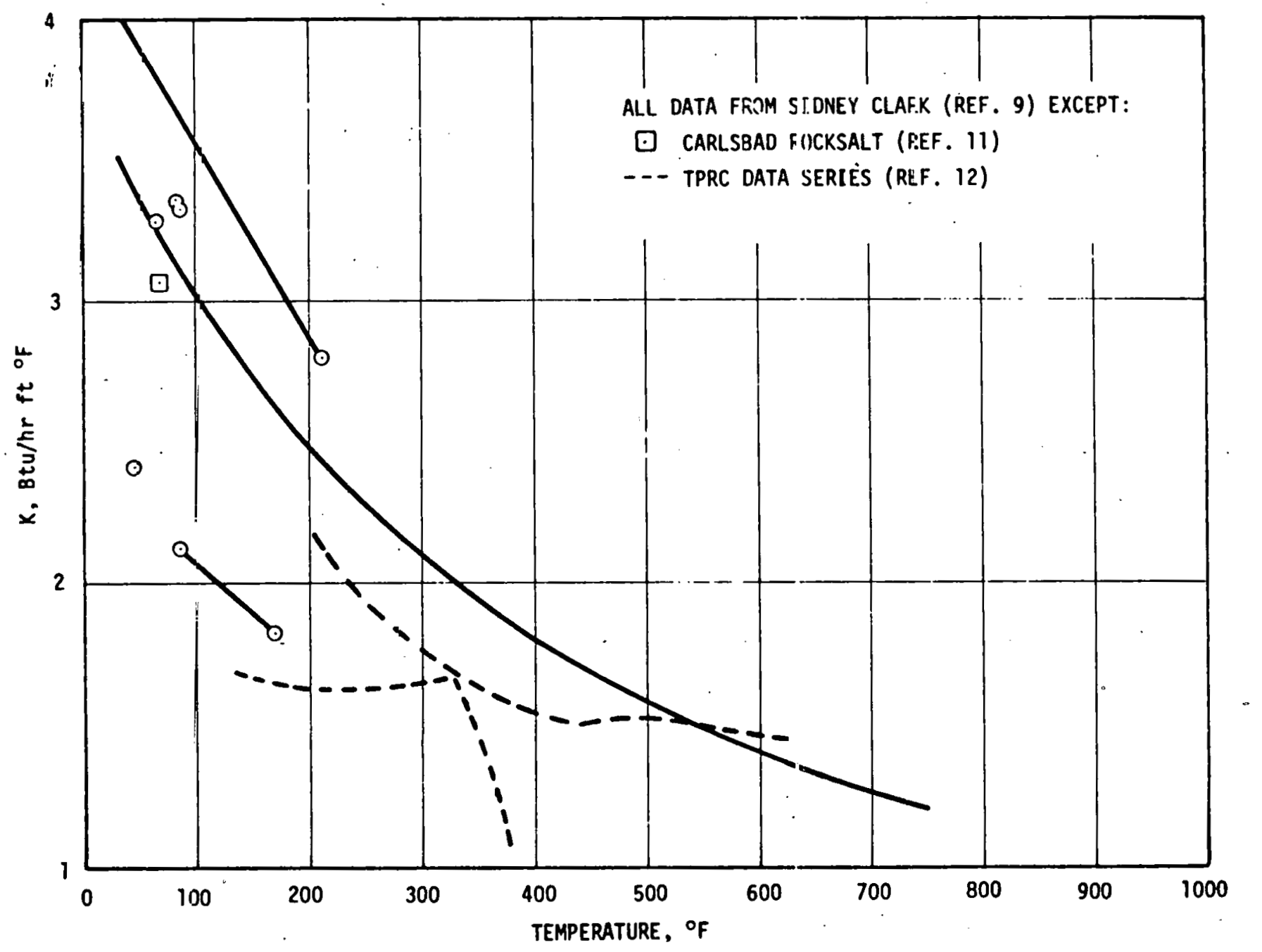

FIGURE 2-8. THERMAL CONDUCTIVITY OF SALT 
In summary, al though the geologic media thermophysical properties used here are thought to be representative values, it must be recognized that fairly wide variations are possible, some of which may affect the results presented here. These results should be re-calculated when a specific site has been selected, and when definitive properties for that site have been determined from borehole samples.

\subsubsection{Thermal Criteria}

The thermal criteria, or temperature limits, that were assumed are described below: These temperature limits, when combined with the thermal models and thermophysical properties directly resulted in the canister constivints reported in Section 3.

\section{2.: Waste Forms}

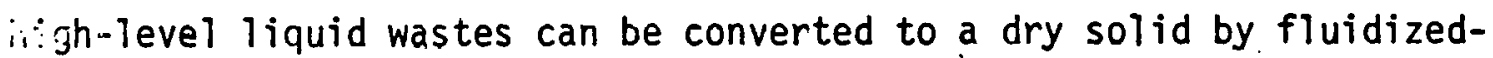

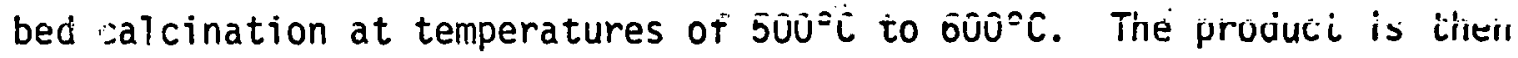
stabiiized, or denitrated, at a temperature of $600^{\circ} \mathrm{C}$ to $750^{\circ} \mathrm{C}$. The stabilized calcine resulting from this process has nitrate and water contents of less than 0.02 and 0.006 weight percent, respectively. In order to avoid the canister pressurization that would be incurred by further volatization of these residuals, and the volatization of ruthenium and cesium in the waste, which occurs at approximately $750^{\circ} \mathrm{C}$ and higher, a maximum allowable temperature for stabilized calcine of $700^{\circ} \mathrm{C}$ was used (Reference 14).

Calcine has the undesirable property of relatively high leachability in water. This property can be improved by combining the calcine with glass frit, pouring the mixture into a canister and melting the mixture at approximately $1100^{\circ} \mathrm{C}$. When cooled, the resultant borosilicate glass form is a solid with low leachability. However, the property of low leachability is destroyed at elevated temperature because the glass devitrifies. Therefore, the maximum allowable temperature of glass is dictated by. the need to avoid devitrification. A review of the literature indicated that this temperature limit has been variously taken at anywhere from $550^{\circ} \mathrm{C}$ up to the glass processing temperature of approximately $1100^{\circ} \mathrm{C}$. BPNL is responsible for developing the borosilicate glass as a part of their Commercial High-Level Waste Fixation Program and, based on 
a discussion (Reference 3 ) with personnel from that agency, a maximum allowable temperature of $800^{\circ} \mathrm{C}$ was selected for this study.

\subsubsection{Structural Materials}

The canister material, 304L stainless steel, is susceptible to stress corrosion cracking if it has been sensitized (Reference 15). Sensitization is the process in which trace amounts of carbon, present as an impurity in 304L, combine with chromium to form chromium carbide. The carbide migrates to the grain boundaries and affects the material's strength and corrosion properties. Sensitization of $304 \mathrm{~L}$ occurs in the temperature range from $430^{\circ} \mathrm{C}$ to $790^{\circ} \mathrm{C}$ (Reference 15 ); however, to avoid sensitization an upperlimit temperature of $350^{\circ} \mathrm{C}$ was conservatively selected (Reference 16) for this study.

The primary concern with a sensitized canister is its decreased integrity if stressed and exposed to a water environment, esnecially if the chloride and oxygen levels in the water are uncontrolled. A sensitized canister which is stressed and exposed to an air environment appears to be of lesser concern (Reference 15).

A canister containing borosilicate glass which was produced by in-can melting will have been sensitized as the result of heat-up to the glass melting temperature (approximately $1100^{\circ} \mathrm{C}$ ) and during cooldown. However, as the degree of sensitization is both time- and temperature-dependent, the extent of the sensitization incurred by in-can melting can be minimized by proper temperature scheduling. Additionally, the glass-filled canister. will be under an elastic tensile load stress after the glass has solidified and the canister has reached thermal equilibrium,

A calcine-filled canișter will also have been sensitized if it is used as the containment vessel during stabilization.

Thus, the effect of constraining glass- and calcine-filled canister temperatures to $350^{\circ} \mathrm{C}$ during interim storage, regardless of whether they are overpacked, was investigated in this study. Such a constraint was not considered to be a baseline criterion for geologic storage (Section 3.2.2 and 3.3.2); however, it was investigated as an alternate approach and is discussed in Section 3.5. 
No temperature constraints were imposed on the overpack or the sleeve. Because of the radial, outward heat flow these components will always be at a temperature lower than that of the canister.

\subsubsection{Repository Media}

The following temperature limits have been prescribed (Reference 5) for a repository located in salt, based on early. test results obtained in connection with Project Salt Vault (Reference 10):

- No more than 1 percent of the salt in a unit cel1 ${ }^{*}$ shall be at a temperature above $250^{\circ} \mathrm{C}$.

- No more than 25 percent of the salt in a unit cell shall be at a temperature above $200^{\circ} \mathrm{C}$.

These values were used in the present study.

No temperature limits have been prescribed for shale and basalt, and none were used in this study. This is an area which requires further definition as, for example, shale fractures at elevated temperature, thus affecting mine stability and further decreasing its thermal conductivity perpendicular to the bed.

\section{2:2.5 Thermal Models}

The following paragraphs describe the thermal models which were used for steady-state and transient thermal analysis of the system described in Section 2.2.2. Included are the rationale for selection of each model and a description of the model details.

\subsubsection{One-Dimensional Model}

A one-dimensional thermal model was used to analyze the canister, with or without an overpack, in interim storage at the FRP. Two storage concepts were addressed: passive air cooling and recirculating water cooling. The one-dimensional (radial) model yields results which are generally applicable to a plane perpendicular to the waste/canister/overpack (optional) axis of symmetry at a point halfway between the ends of the waste-filled section (i.e., four feet from the bottom of the canister).

${ }^{*} A$ 'unit cell' is the volume of salt whose area is defined by the adiabatic boundary concentric with the canister and whose thickness is equal to the height of the canister. 
For the air-cooled storage concept the canister, with or without overpack, was assumed to be stored in a vertical position. Other canisters were assumed to be at a sufficient distance that thermal interactions could be ignored. Thus, heat transfer is by free convection and radiation to an ambient heat sink. The ambient air temperature, and the temperature of the surroundings to which the outer surface radiates, were both assumed to be $26.7^{\circ} \mathrm{C}\left(80^{\circ} \mathrm{F}\right)$. Convective heat trans fer from the vertical wall was included. Temperature-dependent surface emissivities of the canister (304L stainless) and the optional overpack (carbon steel) were also included in the model. Modelling of the recirculated watercooled storage concept assumed the water to maintain the surface temperature at $53^{\circ} \mathrm{C}$ (Reference 4 ).

The one-dimensional, radial cherrial model necessarity excludes any circumferential or axial thermal gradients. For the calcine-filled canister there will be no circumferential gradient, because of the homogeneous waste form. There will be an axial gradient resulting from increased heat losses at the ends due to the surface area of the end caps. However, this axial gradient is expected to be small, due to the high length-to-diameter ratio (approximately 10:1). Therefore, the onedimensional model provides a very good approximation for the calcinefilled canister in either mode of storage.

For the borosilicate glass-filled canister, the volume and thermal power of the glass displaced by the fins were accounted for. The glassfilled canister will exhibit a circumferential gradient, due to the fins, and an axial gradient, due to the fins and the canister end-caps. In the model, the effect of the fins was simulated by 'smearing' the fins and obtaining effective thermophysical properties for the glass/fin combination." This simulation is reasonably valid in predicting waste centerline temperature because the fins do not extend all the way to the centerline. These fins will impose some, circumferential temperature distribution on the canister; however, because the fins do not extend all the way to the canister, and because the canister has a relatively high thermal conductivity, the circumferential temperature distribution is expected to be minimal. Additionally, the axial gradient in the glass-filled canister may be greater than for the calcine-filled canister because of the higher 
axial conduction afforded by the glass/fin combination. Overall, however, such gradients are expected to be very small and the one-dimensional thermal model can be assumed to provide a reasonable approximation for the finned, glass-filled canister.

\subsubsection{Two-Dimensional Model}

A two-dimensional thermal model was used for transient thermal analysis of overpacked canisters in geologic storage at repositories located in salt, shale and basalt formations. The primary objective of the analysis was to determine the maximum allowable size and heat load of canisters which would be consistent with the temperature limits for the waste, canister, and geologic media described in Section 2.2.4.

The canister must be modeled in detail in order to determine the peak temperatures of the waste and canister. In turn, the thermal response of the waste and canister are coupled to the thermal response of the surrounding medium in the repository. That is, variables in the repository configuration such as the distance between canisters, the presence of a backfilled room above the canisters, and the thermophysical characteristics of the repository medium affect the thermal behavior within the canister. Therefore, the detailed canister model must be coupled to a detailed model of an appropriately selected portion of the repository. Thus, a relatively large and complex thermal model is indicated; ideally, it should be threedimensional. However, the short time available to conduct this study necessarily ronstrained the model to be two-dimensional. A two-dimensional model of the repository can be constructed in any of three different ways: it was, therefore, necessary to judiciously select that model which would yield accurate results for the canister.

An $X-Y-Z$ coordinate system can be defined for the repository with the $Z$ axis located along the local vertical. A horizontal cut, in the $X-Y$ plane, allows for detailed modeling of the canister cross-section, but neglects the heat flow in the axial ( $Z$ ) direction. Therefore, this model provides invalid results because it neglects the heat absorbing capacity of the massive volume of geologic medium above and below the cross-section. Alternately, a vertical cut, in the $x-z$ plane, while 
valid for far-field analysis of the repository, does not allow accurate modeling of the canister. Clearly, an R-Z, cylindrical coordinate system must be used in order to include all directions of heat flow and to allow the canister to be modeled in detail.

Assuming that canisters are emplaced in the mine floor in a matrix consisting of several rows, and assuming that the canisters have identical heat-generation characteristics, an adiabatic boundary will be established around each canister which can be approximated as a circular boundary as shown in Figure 2-9. This boundary has a diameter equal to the pitch, P. Extending this boundary to the earth's surface, and down to some arbitrary depth (assumed to be ten thousand feet below the mine) results in the cell shown in Figure 2-10. This cell is ideally suited to characterization in the $R-Z$, cylindrical coordinate system.

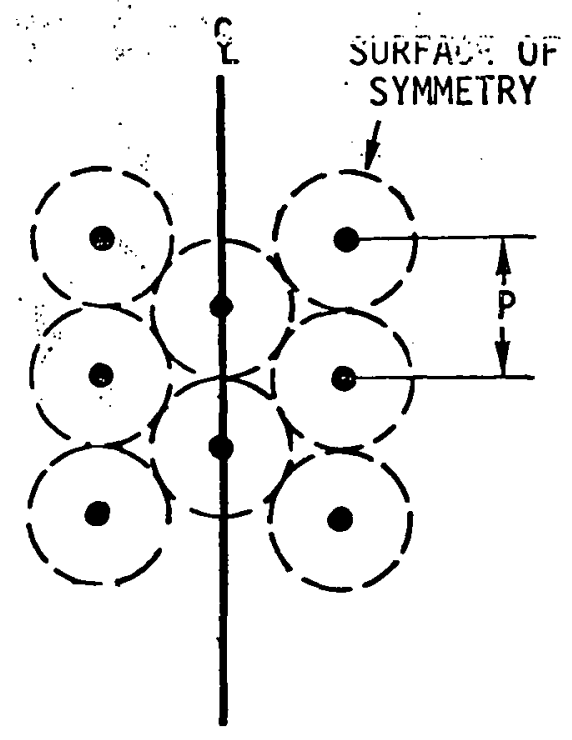

FIGURE 2-9. CANISTER MATRIX SHOWING APPROXIMATE SYMMETRICAL BOUNDARY

The $R-Z$ coordinate system has limitations which alise from the axisymmetric constraint: only configurations which are axisymetric can be treated exactly but some that are not axisymmetric may.be reasonably approximated as such. The configuration shown in Figure 2-10 is axisymmetric because the mine room and backfill cover the entire cell and the canister is a concentric cylinder. A case with internal fins in the 


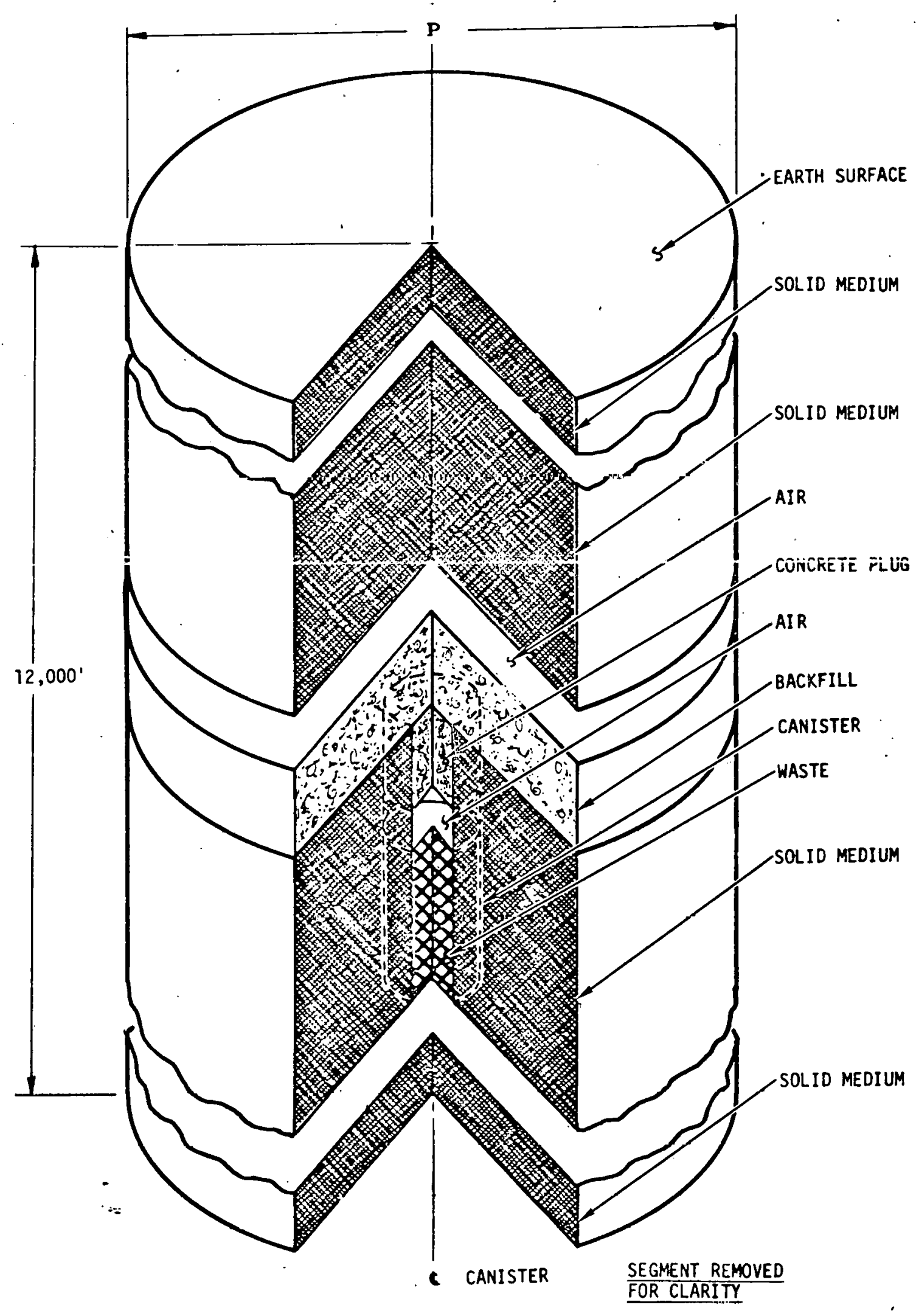

FIGURE 2-10. CELL DEFINED FOR THE R-Z MODEL 
canister can be simulated with the $R-Z$ model if an appropriate effective waste conductivity is assumed. In this approach the fins are "smeared" such that the overall effect of the fins is accounted for. A situation that cannot reasonably be handled in the axisyminetric system is an asymmetric mine room: in this case a three dimensional model is necessary.

Solution Method. The thermal analyzer computer program SINDA was chosen as the solution tool for the canister-repository analysis. The solution method of SINDA is based on a lumped-parameter representation of a physical system. Using this method a physical system is represented as an equivalent thermal network having nodes with a specific capacitance which are connected by heat flow paths, or "conductors", through which heat is driven by the temperature difference between nodes. The important heat transfer mechanisms of conduction, radiation and convection can be modeled with SINDA, along with heat sources and sinks. The capacity, $C$, of a node $i$ is derined by its volume, $v$, deinsity, $\rho$, and specific hea't, $c_{p}$, as

$$
c_{i}=\rho V_{i} c_{p_{i}}
$$

For conduction the value of the conductance, $G$, is defined by the thermal conductivity of the material, $k$, the cross-sectional area, $A$, and the length, $L$, of the flow path as

$$
G_{i}=k A / L
$$

Radiation and convection conductors are discussed in a subsequent section (Model Details). The nodalization of the canister-repository system is also described in the Model Details section, while the numerical solution techniques of SINDA and their application to the long-term geologic storage thermal problem are discussed below.

Given a thermal network model set up for SINDA solution, a variety of numerical methods are available within the SINDA framework for transient solutions. Each of these methods involyes the solution of a set of ordinary, non-linear differential equations obtained by taking a heat balance on each node $i$ as shown below. 


$$
\frac{d T_{i}}{d t}=\frac{1}{c_{i}}\left[q_{i}+\sum_{j=1}^{N} G_{i j}\left(T_{j}-T_{i}\right)\right]
$$

where $N$ is the number of adjacent nodes, $j$, connected to node $i$ and $q_{i}$ is the heat per unit volume generated in node $i$. The various numerical solution techniques differ in the finite difference formulation of the timederivative. There are two general classifications of formulations: explicit and implicit. The explicit formulations compute temperatures step-by-step, and the requirement of stability places an upper limit on the time increment. Implicit formulations require a simultaneous computation procedure and are usually unconditionally stable.

The time scale involved in transient solutions for long-term geologic waste storage is unusually large. One is faced with the prospect of simulating a time span of up to one hundred years, or more, with time increments that are constrained by the opposing limitations of accuracy and economy. Clearly, an implicit solution scheme must be used so that no minimum time step is required for stability. As the solution progresses in time, larger and larger time steps can then be taken as the dynamic nature of the model slows.

In examining the available SINDA implicit finite difference methods the backward-time-difference method was identified as the most likely candidate. The computational procedure used to solve the set of simultaneous equations is a reiterative one. This reiterative backwarddifference solution technique was found to be too slow in convergence for the time increments necessary and some degree of radiation "wobble" was identified as a problem.

Using a technique reported in Reference 16 the convergence problem was solved by developing a backward-time-difference method that uses a Newton-Raphson iteration computational procedure to solve the set of simultaneous equations. The backward difference system consists of simultaneous equations of the form: 


$$
\frac{C_{j}}{\Delta t}\left(T_{i}^{\circ}-T_{j}\right)=\sum_{j=1}^{N} G_{i j}\left(T_{j}^{\circ}-T_{j}^{0}\right)+q_{j}
$$

where the superscript $\left({ }^{\circ}\right)$ denotes the temperatures at a new time. An existing steady-state solution routine that employs the Newton-Raphson computational procedure was modified to account for the transient energy storage term on the left side of the above equation. This was accomplished by connecting to each node $i$ in the model a psuedo-boundary node. The conductor between the boundary node and the model node is given a conductance of value $c_{j} / \Delta t$. Before each step the pseudo-boundary node is set to the current temperature $\left(T_{j}\right)$ of $i$ ts corresponding node $i$ and the conductance is computed based on the time step $(\Delta t)$ and the capacitance of node $i\left(c_{i}\right)$. The pseudo node is held constant at $T_{i}$ while new temperatures $T_{j}^{\circ}$ are calculated for the next time. Essentiaiiy, a sieaciystate solution is performed at each time step by treating the $c_{i} / \Delta t$ as if it is a conductor between two nodes in "space", rather than in time.

This procedure was tested against classical transient solutions for its accuracy and proved to be quite satisfactory. Time increments from a few days at start-up, to a year at late times when temperature changes are very slow, have been used with no convergence problems.

Model Details. The nodalization and heat transfer considerations of the thermal model are discussed in this section. A typical nudal configuration in the $R-Z$ model is shown in Figure 2-11. Each node in the $\mathrm{R}-\mathrm{Z}$ model consists of an annular ring. In the radial direction each ring or node is connected to $i$ ts respective inner and outer concentric rings by a radial conductor. Axially, the nodes are stacked one on top of another and connected by axial conductors. The value of a radial conductor is calculated by the formula

$$
G=2 \pi \cdot \theta / \ln \left(R_{0} / R_{i}\right)
$$

where $\theta$ is the thickncss of the annular ring and $R_{i}$ and $R_{0}$ are the radi $i$ to the inner and outer nodes, respectively. This formula takes into 


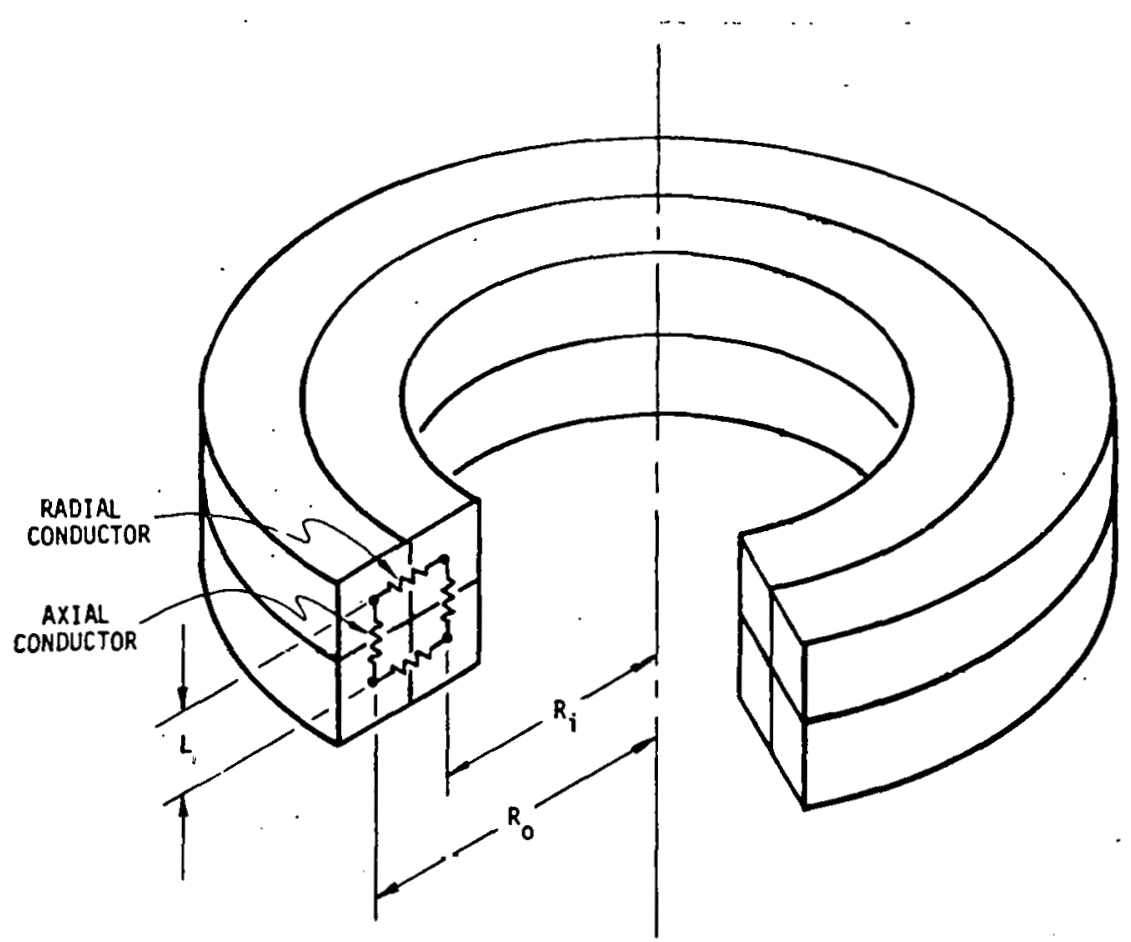

FIGIIRF ? ?. TYPICAL NODE AND CONDUCTOR CONFIGURATION IN R-Ź MODEL

account the increasing area perpendicular to the heat flows. Axial conductance is computed by

$$
G=K A / L
$$

where $A$ is the constant area perpendicular to the conductor and $L$ is the length between nodes.

Figure 2-12 shows a vertical cross-section of the nodalized unit cell. Canister detail is not included here. Each rectangular section in this figure represents an annular ring and thus a node. Each node is connected by radial and axial conductors as previously described except across the room air space where radiation and convection are the heat transfer mechanisms. Note that near the canister the nodes are close together but grow farther apart with increasing distance from the canister. This allows for accurate modeling of regions near the canister in which steep temperature gradients are expected: Fewer nodes are necessary farther $=$ from the canister, where slow changes and mild gradients occur.

Above the room any radial variations are ignored and each node becomes a single disk having a diameter equal to the pitch. It is assumed 


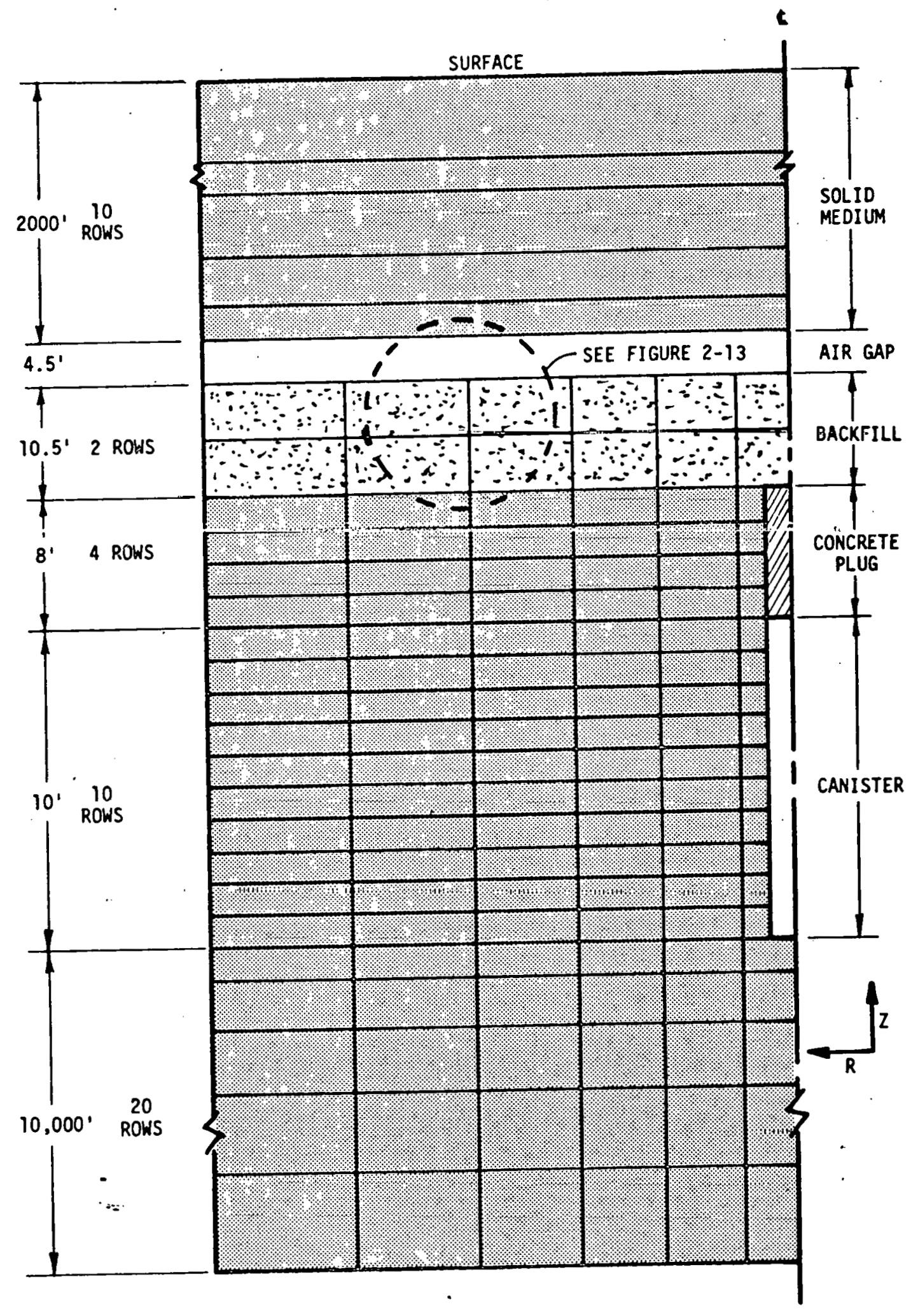

FIGURE 2-12. VERTICAL CROSS SECTION OF NODALIZED CELL 
that the air gap will damp out any radial gradients from below. Each node along the bottom of the air gap is connected to the node above the gap by a convection conductor and a radiation conductor. A cutout of the room area is shown in Figure 2-13.

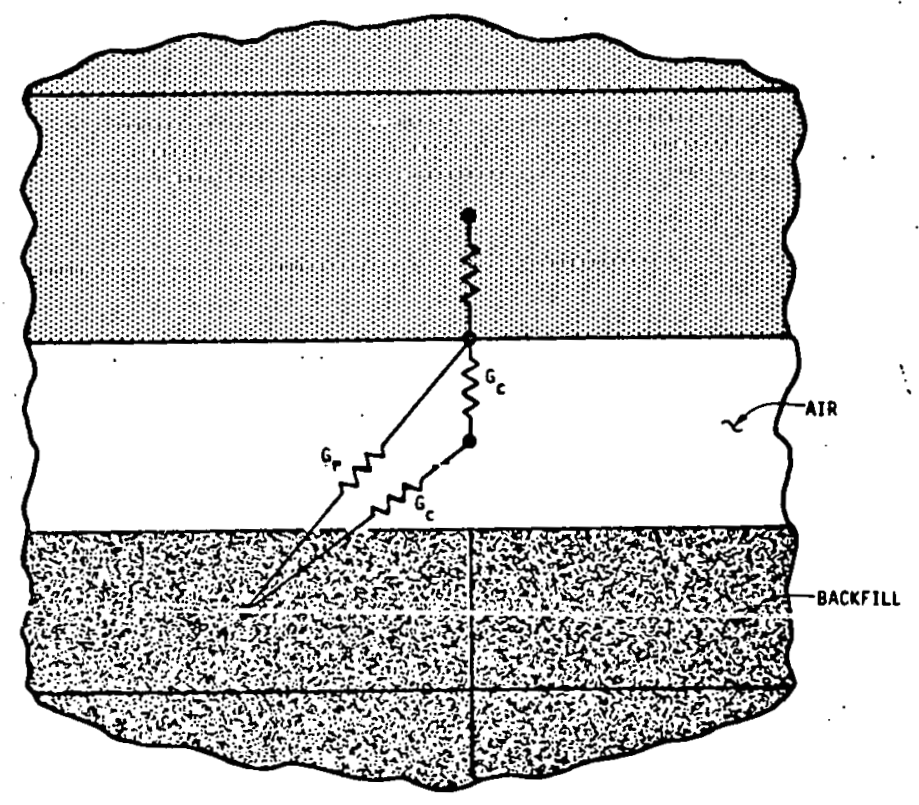

FIGURE 2-13. CUTOUT FROM FIGURE 2-12 SHOWING 'RADIATION AND CONVECTION MODELING OF THE ROOM AIR GAP

Heat is convected from the bottom of the room to the air (represented by a single node in the center) which in turn convects heat to the ceiling. The convective heat transfer coefficient is calculated for natural convection from a horizontal surface. The conductance of a convective path, $G_{c}$, is given by

$$
G_{c}=h_{c} A
$$

where $h_{c}$ is the heat transfer coefficient and $A$ is the area of the convecting node. Radiation exchange between two surfaces of the same emissivity is modeled by a radiation-conductor

$$
G_{r}=\varepsilon \sigma A F
$$


Assuming a shape factor of unity between two parallel surfaces the radiation conductance between a bottom node and the top surface is approximated by

$$
G_{r}=\varepsilon \sigma A_{i} / A_{T o p}
$$

where $A_{i}$ is the area of the bottom node. SINDA automatically changes the driving force of radiation paths to temperature to the fourth power.

The modeling details of the canister and its surrounding area are shown in Figure 2-14. Internally the waste is broken into four radial nodes and eight axial nodes, each connected by conductors as previously described. Forusing attention on a horizontal section containing waste nodes it is seen chat the outer waste node is connected to the adjacent metal canister wa 11 node. Any temperature drop across the metal canister wall or the overpack is ignored so that each section of wall or overpack can be represented by a single node. Each canister wall node is connected to the adjacent overpack node by a conduction conductor and a radiation conductor. Thus, heat is allowed to conduct across the slab of air or radiate between the metal surfaces. Again, a shape factor of unity is assumed and with non-equal surface areas and emissivities the radiation. conductance is given by

$$
G_{r}=\frac{1}{\frac{1-\varepsilon_{i}}{A_{i} \varepsilon_{i}}+\frac{1}{A_{i}}+\frac{1-\varepsilon_{0}}{A_{0} \varepsilon_{0}}}
$$

where the subscripts ( $i$ ) and ( 0 ) denote inner and outer surfaces, respectively. The overpack node is then connected to the first solid repository medium node through a conductor across an annulus of crushed material. Continuing outward in the radial direction are six nodes of increasing size, all of which are connected by radial conductors. The outer boundary of the unit cell is modeled as an adiabatic surface since it is a surface of symmetry in the field of canisters. Each horizonta] section, except at the canister ends, is connected above and below to another identical section by axial conductors as shown in Figure 2-14. 


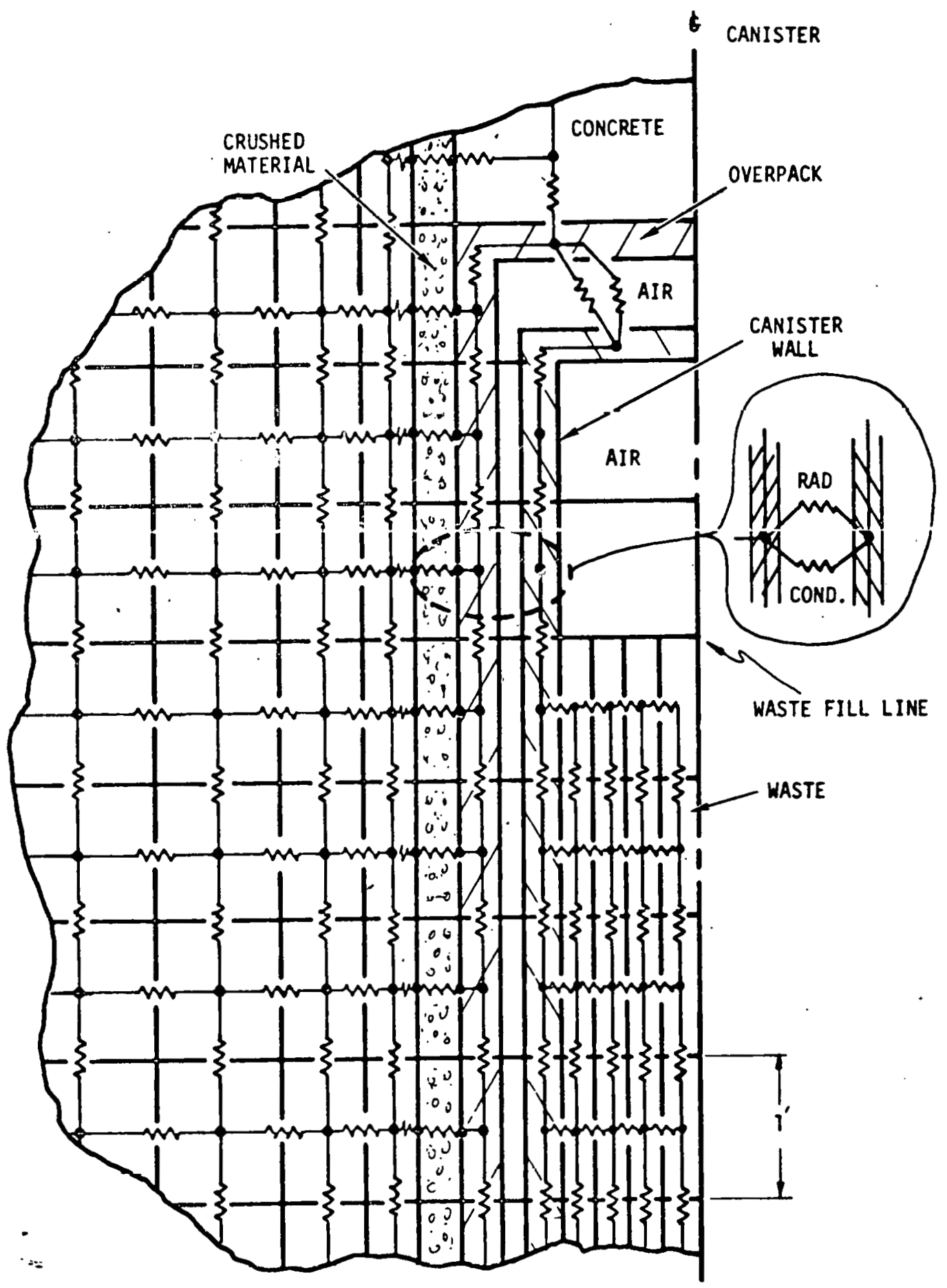

FIGURE 2-14. VERTICAL CROSS-SECTION OF CANISTER AND SURROUNDING AREA SHOWING THERMAL CONDUCTORS AND NODES 
Above the waste-fill line the nodalization is identical except for the missing waste nodes. Across the air space above the canister, convection and radiation are modeled. Note that all the metal nodes are connected axially so that heat is allowed to flow away from the waste, up through the canister wall and the overpack.

The heat generated by the waste is impressed on each waste node based on its volume. At each time step new heat loadings are calculated based on the age of the waste so that the power decay is accounted for.

Fin Modeling. As mentioned previously, the axisymmetric constraint of the R-Z coordinate system does not allow the detailed modeling of internal fins in the canister. The overall effect of the fins, though, can be accounted for by determining an effective conductivity of the glass/fin combination and thus 'smearing' the fins to allow solutions. In estimating the effective conductivity a parallel heat flow path assumption is made for the flow through the fins and the waste.

The two radial heat flow paths are shown in Figure 2-15 for the waste and the fin. For the conductors which include the fin flow path, an overall conductor is calculated in the following manner. The $A / L$ term of the waste conductor is calculated as if the fins were not present by

$$
G_{W} / K_{W}=\theta / \ln \left(R_{0} / R_{i}\right)
$$

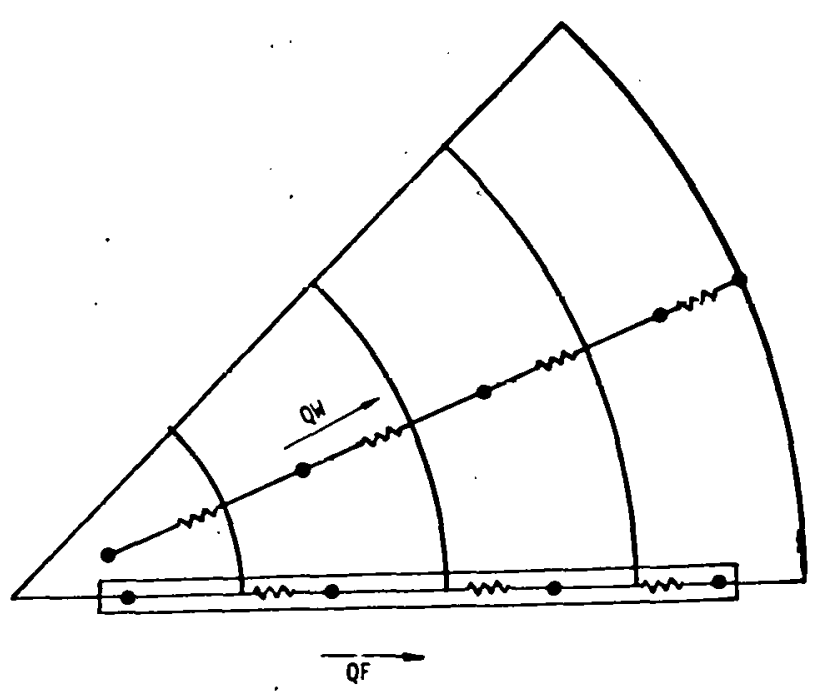

FIGURE 2-15. HORIZONTAL CROSS-SECTION OF CANISTER DEPICTING PARALLEL HEAT FLOW PATHS THROUGH FIN AND WASTE 
The same term for the fin is computed by

$$
G_{F} / K_{F}=A_{F} N_{F} / L
$$

where $A_{F}$ is the cross-sectional area of a fin, $N$. is the number of fins and $L$ is the length between nodes. The waste conductor is then computed by subtracting the $A / L$ for the fins and multiplying by the waste conductivity

$$
G_{W}=k_{W} \cdot\left(G_{W} / k_{W}-G_{F} / k_{F}\right) \text {. }
$$

The fin conductance is then computed based $c: i$ the conductivity of the fin material. The sum of the parallel waste and fin :unductances becomes the efrecíive conductance foù a conductoi that inciutes fiss:

$$
G_{\text {eff }}=G_{W}+G_{F}
$$

The same procedure is taken for axial conductors in accounting for the fins: The displacement volume of the fins is also taken into account when computing the heat sources for each waste node.

The results obtained using this approximation to determine waste centerline and canister surface temperatures dre cumpared in Appendix $C$ to the results obtained for a detailed, two-dimensional model of the same crosssection. As seen in Appendix $C$ there is close agreement in the results. 


\section{RESULTS}

Sections 3.1 and 3.2 describe the design constraints obtained for the baseline cases described in Section 2. Typical temperature histories for these cases are described in Section 3.3. The effects on the design constraints of perturbing the baseine cases are discussed in Section

\subsection{4.}

\subsection{DESIGN CONSTRAINTS FOR CANISTERS CONTAINING BOROSILICATE GLASS}

Following are the results obtained for canisters containing the glass waste form with internal fins.

\subsubsection{Interim Storage}

Figure 3-1 shows, as a function of the waste age since reprocessing, the maximum allowable canister diameter and resulting heat load for a glass-filled, water-cooled canister in interim storage. Water cooling is assumed to maintain the external surface temperature at $53^{\circ} \mathrm{C}$. Three cases are shown in Figure $3-1$, corresponding to three different design approaches.

Case 1 of Figure 3-1 corresponds to a canister, without an overpack, directly cooled by water. The canister surface is maintained at $53^{\circ} \mathrm{C}$; thus, the only constraint on the canister is imposed by the maximum allowable waste temperature of $800^{\circ} \mathrm{C}$. This case results in the greatest allowable diameter and heat. load for any waste age.

Cases 2 and 3 correspond to overpacked canisters. In both cases, smaller diameters and heat loads result due to the thermal resistance caused by the air gap between the overpack and the canister. In Case 2, there is no constraint on the canister temperature: thus, only the waste temperature constrains the canister diameter. The net effect will be that the canister temperature will decrease from $450^{\circ} \mathrm{C}$ for waste aged zero years to $350^{\circ} \mathrm{C}$ or less after 1.8 years. If it is required to limit the canister temperature to $350^{\circ} \mathrm{C}$ or less, in order to avoid sensitization, Case 3 shows that the net effect will be to reduce the canister diameter for waste aged 1.8 years or less: for waste aged over 1.8 years the allowable diameters and resultant heat loads for Case 3 are the same as for Case 2. 


\begin{tabular}{|c|c|c|c|c|}
\hline CASE & OVERPACK & $T_{\text {WASTE }}$ & $T_{\text {CAN }}$ & $T_{0^{\prime} \text { PACK }}$ \\
\hline 1 & NO & $=800^{\circ} \mathrm{C}$ & $-53^{\circ} \mathrm{C}$ & NA \\
\hline 2 & YES & $\leq 800^{\circ} \mathrm{C}$ & $\geq 350^{\circ} \mathrm{C}$ & $=53^{\circ} \mathrm{C}$ \\
\hline 3 & YES & $\leq 800^{\circ} \mathrm{C}$ & $\leq 350^{\circ} \mathrm{C}$ & $=53^{\circ} \mathrm{C}$ \\
\hline
\end{tabular}

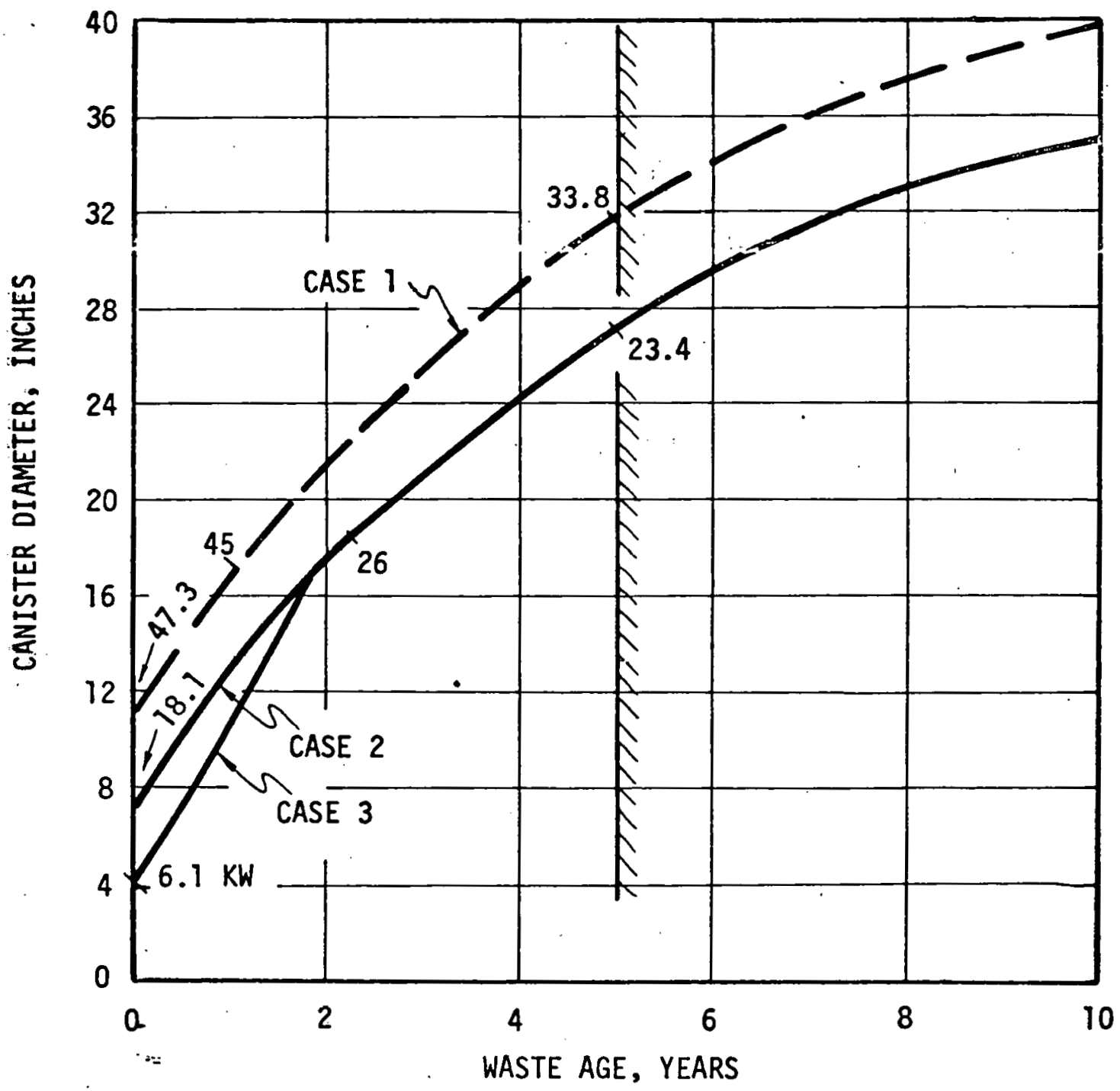

FIGURE 3-1. DESIGN CONSTRAINTS FOR CANISTERS CONTAINING BOROSILICATE GLASS WASTE IN WATER-COOLED INTERIM STORAGE 
It is likely that considerations other than thermal constraints will dictate a minimum practical canister diameter. In this event, figure 3-1 can be used to determine, for a given diameter, the minimum allowable waste age since reprocessing. For example, if a diameter of 12 inches is selected, Figure 3-1 shows that the waste must be from 0.1 year to 1.2 years old, depending on whether the canister is overpacked and whether or not the canister is constrained to a temperature of $350^{\circ} \mathrm{C}$.

Figure 3-1 can also be used to determine the elapsed time necessary before a canister can be overpacked. For example; assume it is necessary to encapsulate 1-year-old waste in the largest possible canister compatible with water cooling and, at a later time, provide it with an overpack. From figure 3-1, the largest canister diameter for 1-year-old waste is 17 inches without an overpack. It is seen that this size canistel can he removed from water cooling, provided with an overpack, and replaced in water cooling, at a waste age of approximately 2 years.

Figure 3-2 shows the maximum allowable canister diameter, as a function of waste age, for a glass-filled canister in ambient air storage.

A canister, without an overpack, is represented by Case 1 of Figure 3-2. For Case 1, it is assumed to be a requirement to limit the canister surface temperature to $350^{\circ} \mathrm{C}$ or less, in order to avoid sensitization., This criterion constrains the diameter for waste aged up to approximately 2.7 years: for older waste the waste temperature constrains the diameter.

Cases 2 and 3 represent an overpacked canister in air. In Case 2, the canister temperature is not constrained. Thus, the waste temperature is the only constraint on canister diameter. In this case, the canister temperature will aiways exceed $350^{\circ} \mathrm{C}$. In Case 3, both constraints apply: canister temperature no greater than $350^{\circ} \mathrm{C}$ and waste temperature no greater than $800^{\circ} \mathrm{C}$.

The minimum waste age required for an air-cooled canister with fixed diameter can also be obtained from figure 3-2.

The canister diameters shown in Figure 3-2 for air-cooled storage are seen to be considerably smaller than the diameters shown in Figure 3-1 for water cooling. In order to provide for the largest possible canister, it may be required to water-cool the canister for a period 


\begin{tabular}{|c|c|c|c|c|}
\hline CASE & OVERPACK & $T_{\text {WASTE }}$ & $T_{\text {CAN }}$ & $T_{O^{\prime} \text { PACK }}$ \\
\hline 1 & NO & $\leq 800^{\circ} \mathrm{C}$ & $\leq 350^{\circ} \mathrm{C}$ & $N A$ \\
\hline 2 & YES & $=800^{\circ} \mathrm{C}$ & $\geq 350^{\circ} \mathrm{C}$ & $\geq 350^{\circ} \mathrm{C}$ \\
\hline 3 & YES & $\leq 800^{\circ} \mathrm{C}$ & $\leq 350^{\circ} \mathrm{C}$ & $<350^{\circ} \mathrm{C}$ \\
\hline
\end{tabular}

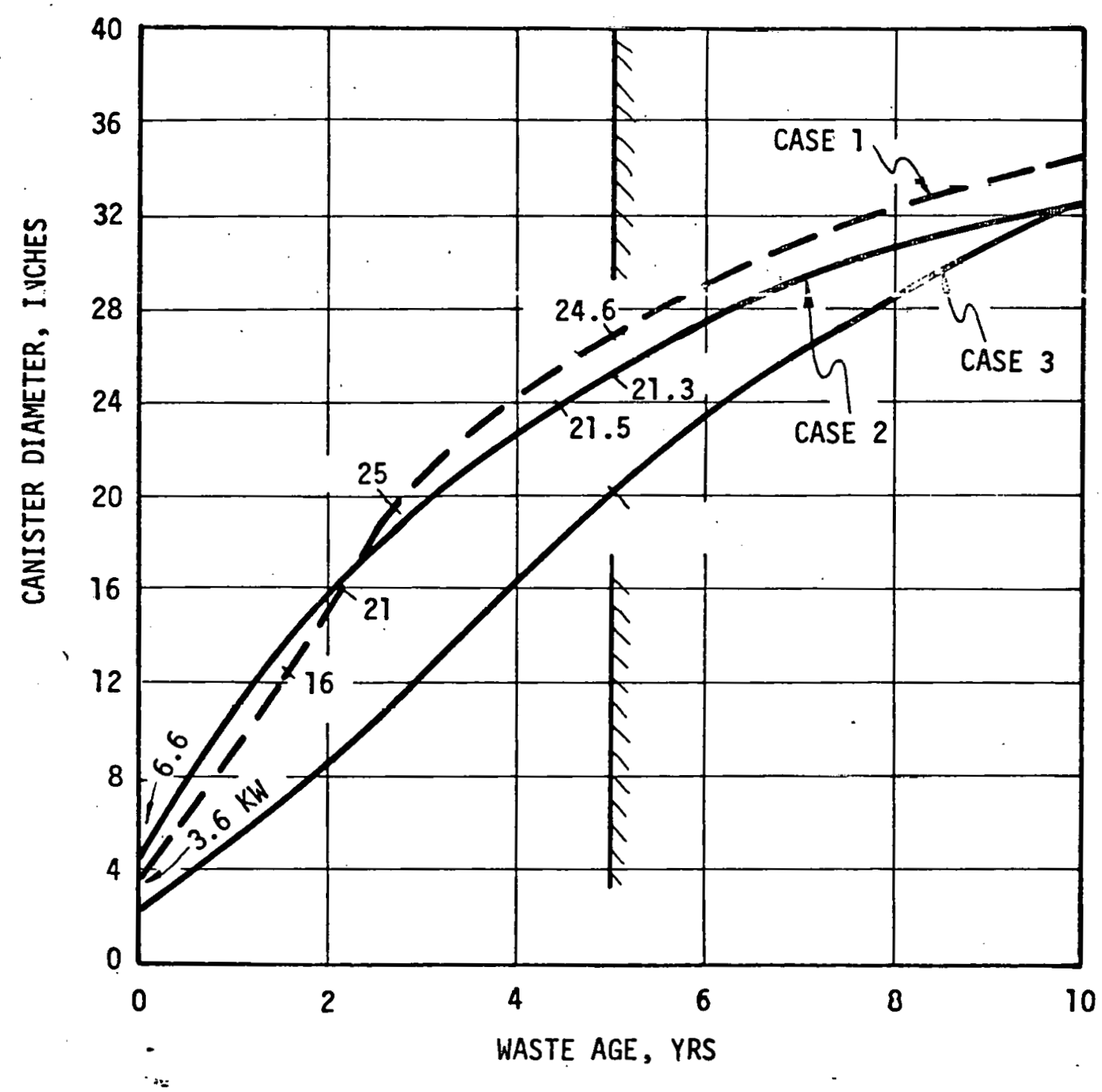

FIGURE 3-2. DESIGN CONSTRAINTS FOR CANISTERS CONTAINING BOROSILICATE GLASS IN AIR-COOLED INTERIM STORAGE 
prior to subjecting it to air-cooling. If, for example, it is necessary to use an overpacked, 12-inch diameter canister, and maintain the canister at $350^{\circ} \mathrm{C}$ or below, Figure $3-1$ shows that a minimum waste age of 1.2 years is required. Figure 3-2 shows that the same canister can be air-cooled at a waste age of 3 years. Thus, the canister need only be water-cooled for approximately 22 months.

\subsubsection{Geologic Storage}

Figure $3-3^{*}$ shows the maximum allowable diameters and heat loads for glass-filled canisters emplaced in a salt repository. For a pitch of up

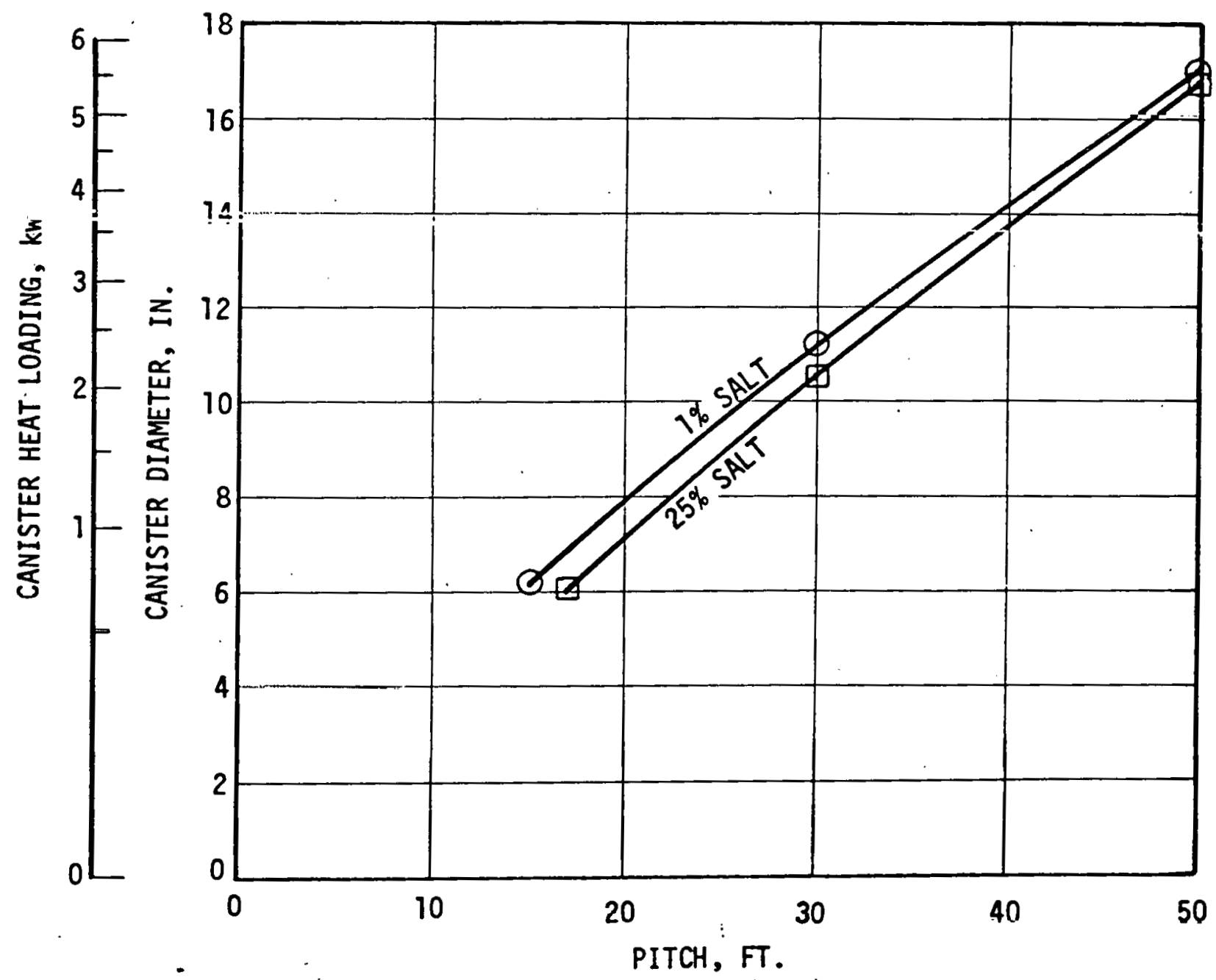

FIGURE 3 $\because 3$. DESIGN CONSTRAINTS FOR CANISTERS CONTAINING BOROSILICATE GLASS STORED IN A SALT REPOSITORY (10-YEAR-OLD PWR WASTE; CANISTER WITH OVERPACK)

*A11 geologic storage curves assume a minimum practical canister diameter of 6 inches. Also, canister spacings of up to 50 feet are shown, although greater spacings are, of course, possible. 
to 50 feet, the allowable diameter increases with increasing pitch, and is constrained by the 25 percent salt temperature criterion. Convergence of the two salt temperature criteria indicates that the one percent salt temperature criterion will become the dominant constraint at some pitch greater than 50 feet. The waste temperature criterion does not constrain diameter within the envelope shown; however, extrapolation of the results indicated that the waste temperature dominates at a pitch of approximately 70 feet or more, and constrains the glass-filled canister to approximately 22 inches in diameter, with a corresponding heat load of $9 \mathrm{kw}$.

The canister design constraints in a shale repository are shown in Figure 3-4. Lacking definitive data on shale temperature limits, the waste temperature criterion is the only constraint on diameter. Allowable diameter is seen to increase with pitch up to a pitch of 50 feet, beyond

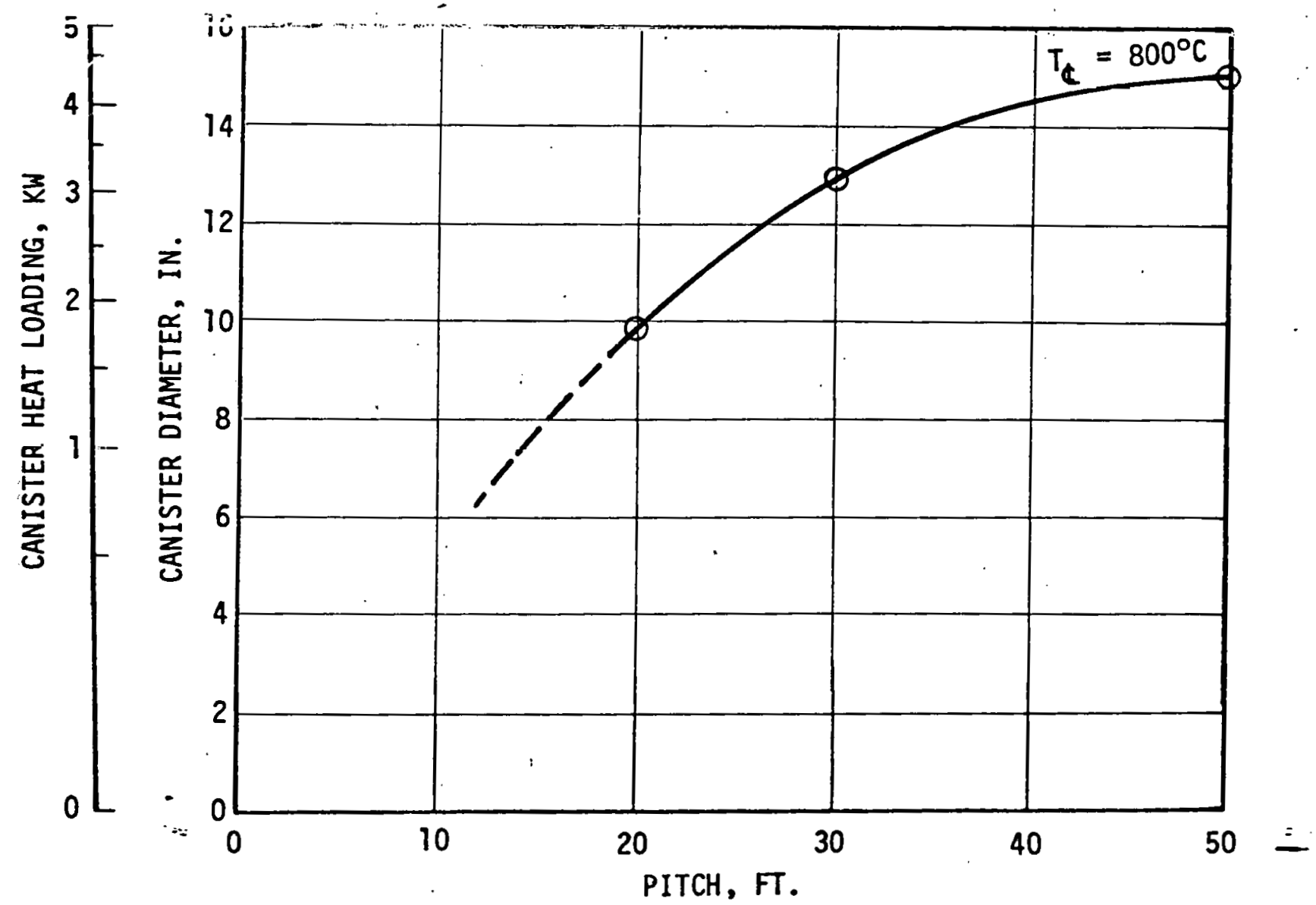

FIGURE 3-4. DESIGN CONSTRAINTS FOR CANISTĖRS CONTAINING BOROSILICATE GLASS STORED IN A SHALE REPOSITORY (10-YEAR-OLD PWR WASTE; CANISTER WITH OVERPACK) 
which the allowable diameter stays constant ai approximately 15 inches, corresponding to a heat load of $4.3 \mathrm{kw}$. Restated, a canister with diameter greater than approximately 15 inches will cause the waste centerline temperature to exceed $800^{\circ} \mathrm{C}$, regardless of the spacing.

The results for a basalt repository are shown in Figure 3-5. As for shale, the only constraint for canisters in a basalt repository is assumed to be the waste temperature criterion. The allowable diameter is seen to increase with increasing pitch up to a pitch of 50 feet, beyond which it is constrained to approximately 19 inches, corresponding to a heat load of $7.0 \mathrm{kw}$.

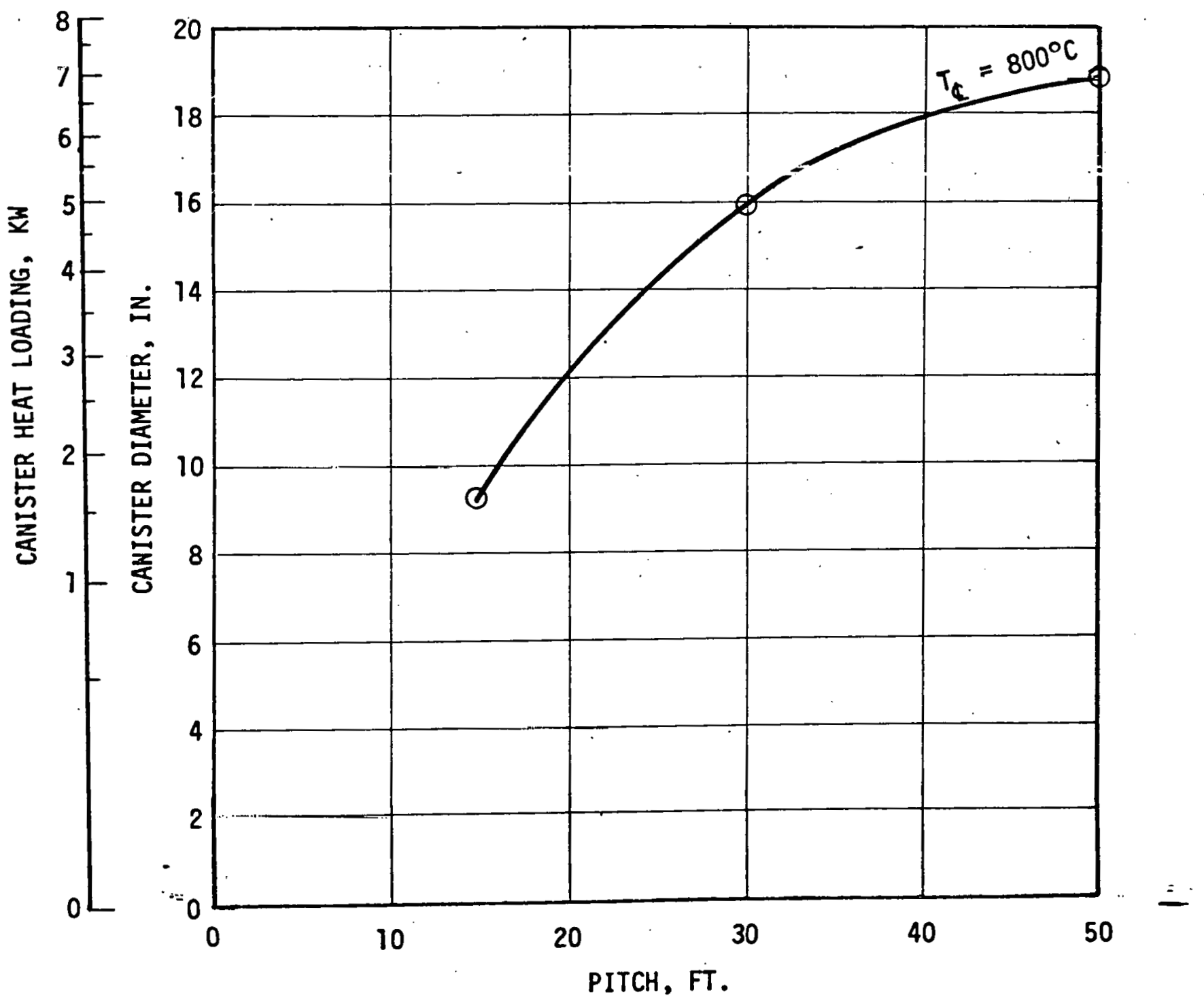

FIGURE 3-5. DESIGN CONSTRAINTS FOR CANISTERS CONTAINING BOROSILICATE GLASS IN A BASALT REPOSITORY (10-YEAR-OLD PWR WASTE; CANISTER WITH OVERPACK) 
From the foregoing results it is seen that the allowable canister diameter generally increases with pitch until the maximum allowable diameter is reached. Thus, there is a range of acceptable sizes for each repository medium. Because the fixed costs of real estate and mining will vary approximately directly with the mine area required, it is desirable to determine if, within these canister diameter ranges, there is a diameter which minimizes the required mine area. Figures 3-3, 3-4 and 3-5 have been replotted in Figure 3-6 to show the mine area requirements (per 1000 MTU of fuel reprocessed) for the three geologic media. The desirability of one geologic medium over another cannot be inferred from Figure 3-6 because of the different mining cost for each medium. Addi-. tionally, it must be reiterated that the curves for shale and basalt do not include any constraints on repository temperatures.

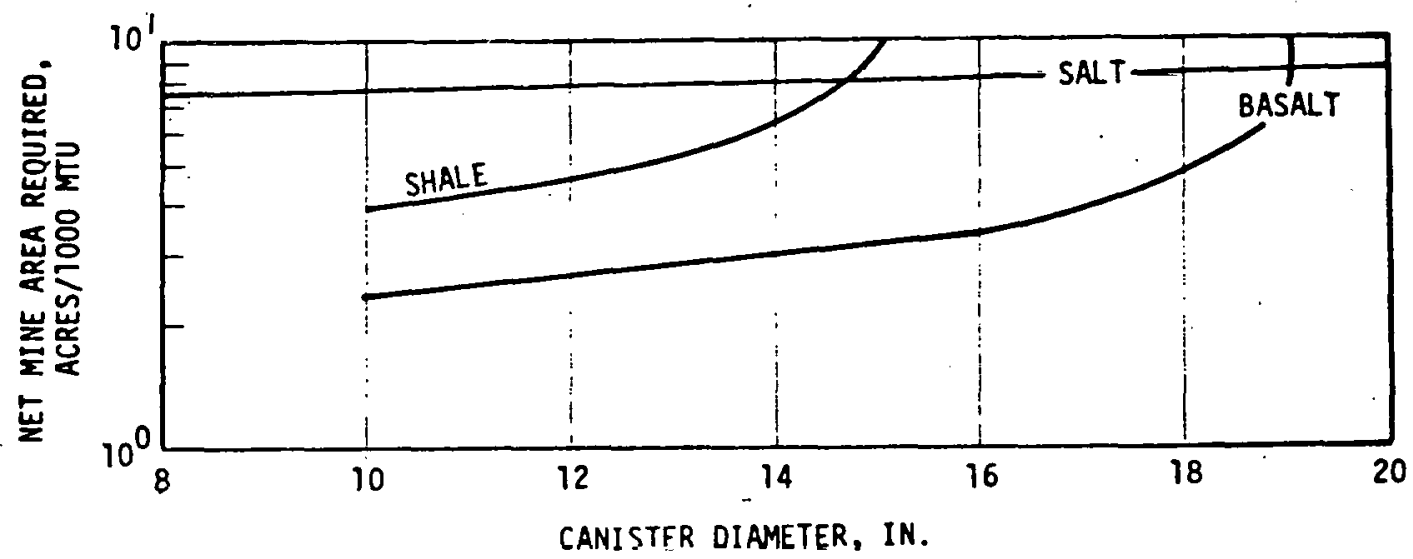

:FIGURE 3-6. NET MINE AREA REQUIREMENTS FOR OVERPACKED, GLASS-FILLED CANISTERS

With these qualifications, Figure 3-6 can be used to determine the trends for each medium. For a repository in salt, the mine area required is constrained by the salt temperature criteria and is essentially independent of canister diameter. However, for shale and basalt, the net mine area, which is constrained by the allowable waste temperature, is seen to decrease with decreasing canister diameter. This suggests that, for shale and basalt, many small canisters are preferable to fewer large canisters.

On the other hand, for a fixed quantity of waste, the variable costs associated with handling, possible overpacking, in-mine transportation and 
canister hole boring probably increase in proportion to the total number of canisters processed. This suggests that a small number of large canisters is preferable for salt. However, for shale and basalt, these qualitative considerations of fixed and variable costs suggest that there may be a cost-optimum canister diameter for each of the two media; however, such an investigation is outside the scope of the current study.

\section{1 .3 Surmary}

In the preceding results for glass-filled canisters, the criterion which most often constrains the canister size is seen to be the maximum allowable glass temperature of $800^{\circ} \mathrm{C}$. Because the glass centerline temperature is directly affected by the fins, it is very important to recognize that the resilts described above apply only to the fin design adopted for this siddy (see Section 2.2.1). Up to a point, fins of increased thickriess, or more fins, will allow greater canister sizes and heat loads than shown here, even accounting for the waste displaced by these fins. Other forms of centerline cooling, such as waste dilution or the substitution of an annular canister, could also be employed to obtain larger canisters with increased heat loads.

A canister must be designed to be compatible with the design constraints imposed by both the cooling method selected for interim storage and the repository medium for which the canister is destined. Therefore, Figures 3-1 and 3-2, and Figures 3-3 through 3-5 must be assessed collectively. Repositories in salt, shale and basalt can accept glassfilled canisters of up to 22 inches, 15 inches and 19 inches diameter, respectively. Reference to Figures $3-1$ and 3-2 indicates the minimum allowable waste age for these diameters as a function of the interim storage mode selected

For the following reasons, it may be desirable to water-cool glassfilled canisters during interim storage at the FRP rather than use aircooled storage:

- Water basin cooling (of spent fuel assemblies) is state-of-the-art.

- Water cooling is a more effective heat transfer medium, thus allowing larger canister diameters.

- Water basins provide greater protection against accidental mechanical impact. 
However, because the canisters will have been sensitized, to a degree, as the result of the in-can melting process, and because they will be under an elastic tensile stress ${ }^{*}$, it may be desirable to overpack the canister prior to water-cooled interim storage rather than deferring this operation until later. In water-cooled storage, overpacked canisters provide an added benefit (Reference $A$ ): overpacking eliminates the requirements for concrete cover blocks and eliminates the need for a two-loop water cooling system because of the lowered probability of contaminating the basin water with a falled canister. Also eliminated are the diversion features of the ventilation system in the storage area which provide the option of routing the exhaust air through a HEPA filter prior to discharge to the stack.

Figure 3-1 can then be used to determine the minimum waste age required for glass-filled canisters. which are overpacked and water-cooled in interim storage. For the 22-inch-diameter canister destined for sait, a waste age of 3.3 years or greater is required. For shale, the 15-inchdiameter canister requires waste aged approximately 1.6 years. For basalt, a 16-inch diameter requires waste aged approximately 1.7 years.

A potential disadvantage with water-cooled interim storage is the degraded integrity of a canister in the event of an accident which results either in failure to circulate the water or in complete loss of water. Such events are of extremely low probability, as redundant pumps and water supply systems will be incorporated. This redundancy notwithstanding, Figure 3-7 shows the transient temperature response of a typical canister following complete and instantaneous loss of water. The canister shown in Figure 3-7 has a diameter of 9.6 inches, has an overpack, contains 1-year-old waste, and is designed to limit the canister surface temperature to $350^{\circ} \mathrm{C}$ during normal conditions of water-conled storage. Thermal equilibrium has been obtained prior to the accident: the overpack temperature is $53^{\circ} \mathrm{C}$, the canister is at $350^{\circ} \mathrm{C}$; and the glass centerline temperature is approximately $540^{\circ} \mathrm{C}$. At time zero, all the water is removed and the temperatures increase with time until reaching a new equillbrium. The overpack equilibrates at approximately $335^{\circ} \mathrm{C}$. The

*Stress relief as, for example, by canister sub-cooling is not currently planned (Reference 4). 


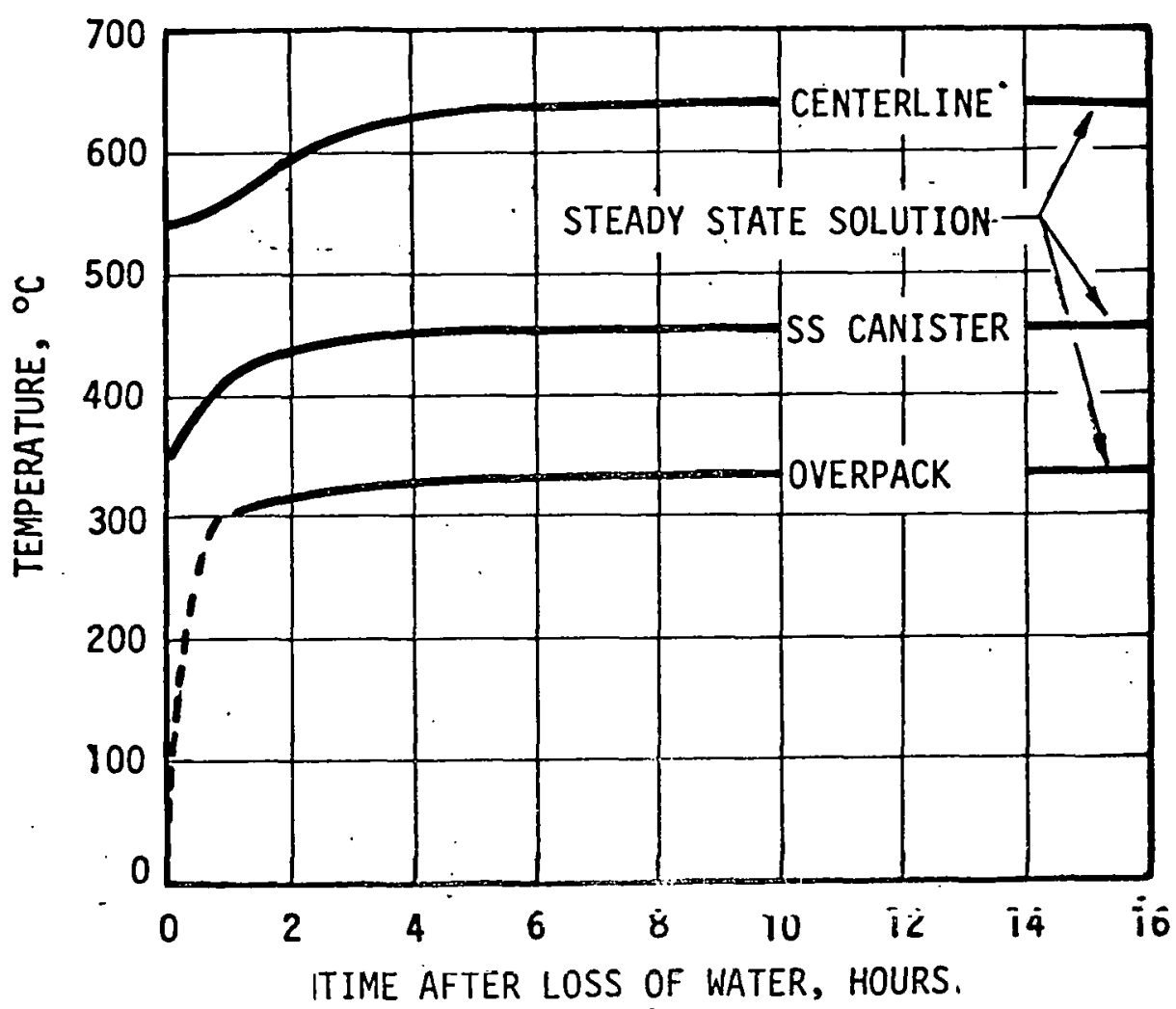

FIGURE 3-7. TEMPERATURE HISTORY OF AN OVERPACKED, GLASS-: FILLED CANISTER FOLLOWING LOSS OF WATER COOLING

canister equilibrium temperature is $455^{\circ} \mathrm{C}$, which is within the temperature regime $\left(430-790^{\circ} \mathrm{C}\right)$ at which sensitization occurs. The peak centerline temperature reaches $640^{\circ} \mathrm{C}$ after approximately 6 hours. Therefore, the overall effect of a loss-of-coolant accident is not seen to be catastrophic.

\subsection{DESIGN CONSTRAINTS FOR CANISTERS. CONTAINING CALCINE}

Following are the results obtained for canisters containing the calcine waste form. The baseline case described below assumed a cylindrical canister configuration: an annular cylinder, internal fins, waste dilution or other forms of calcine temperature reduction are not included in the baseline case, but are discussed separately in Section 3-4.

\subsubsection{Interim Storage}

Figure 3-8 shows the results obtained for calcine-filled canisters in water cooling. Two cases are shown: with and without an overpack. Without an overpack the canister is maintained at $53^{\circ} \mathrm{C}$ and the allowable diameter as a function of waste age is constrained by the waste temperature of $700^{\circ} \mathrm{C}$. In Case 2 , which represents an overpacked canister, 


\begin{tabular}{|c|c|c|c|c|}
\hline CASE & OVERPACK & $T_{\text {WASTE }}$ & $T_{\text {CAN }}$ & $T_{\text {O'PACK }}$ \\
\hline 1 & NO & $=700^{\circ} \mathrm{C}$ & $=53^{\circ} \mathrm{C}$ & $\mathrm{NA}$ \\
\hline 2 & YES & $=700^{\circ} \mathrm{C}$ & $<350^{\circ} \mathrm{C}$ & $=53^{\circ} \mathrm{C}$ \\
\hline
\end{tabular}

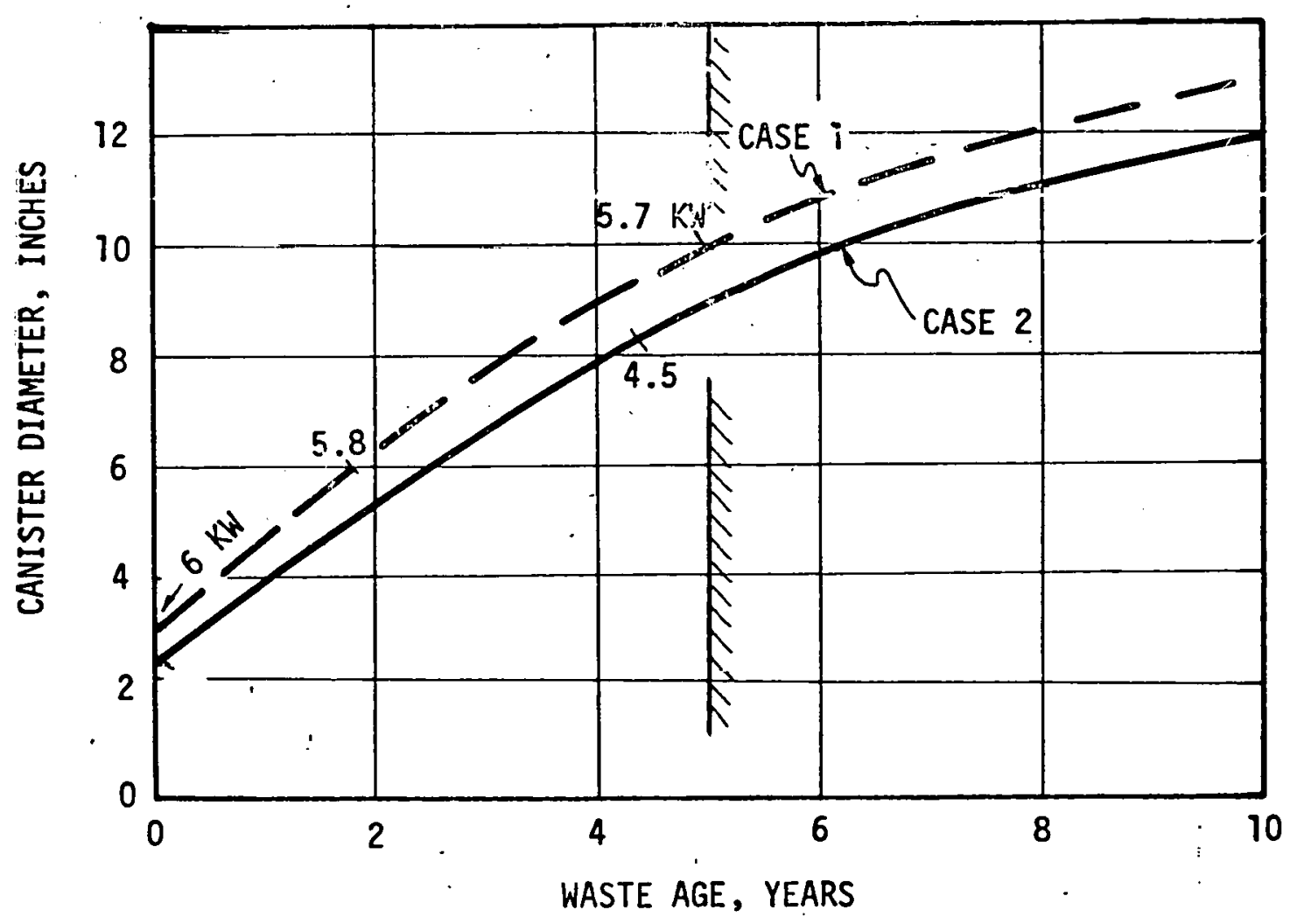

FIGURE 3-8. DESIGN CONSTRAINTS FOR CANISTERS CONTAINING CALCINE WASTE STORED IN WATER-COOLED INTERIM STORAGE 
the diameter is similarly constrained by the waste temperature, regardless of waste age. It was found that the canister temperature is always less than $350^{\circ} \mathrm{C}$ for Case 2.

The results for air-cooled calcine canisters are shown in Figure 3-9. As for glass-filled canisters, three cases are shown. Case 1, without an overpack, is constrained only by the waste temperature and, for the diameters shown, the canister is always at a temperature of less than $350^{\circ} \mathrm{C}$. With an overpack, and allowing the canister to exceed $350^{\circ} \mathrm{C}$, is represented by Case 2." Constraining the canister temperature to $350^{\circ} \mathrm{C}$ is represented by case 3. For short-aged wastes, it can be seen that there is only a slight difference in the results obtained for all three cases.

Comparison of these results with the results obtained for glassfilled canisters in Figures $3-1$ and 3-2 shows that the calcine results in significantly smaller allowable canister diameters and heat loads. These results are caused by a combination of two factors: the lower allowable waste temperature for calcine; and the lower thermal conductivity of calcine compared to the finned glass. For calcine, the maximum possible canister diameter, 10 inches, could be used if the waste is aged for the maximum allowable time (i.e., 5 years), piaced in a canister without an overpack and then placed in water-cooled interim storage. From Figure 3-9, this same canister could be transferred to air-cooled storage 1.5 years later.

\subsubsection{Geologic Storage}

Figure 3-10 shows the maximum allowable canister diameters and heat loadings for calcine-filled canisters emplaced in a salt repository. For a pitch of up to approximately 40 feet, allowable canister diameter increases with pitch, and is constrained by the 25 percent salt temperature criterion. However, at a pitch of greater than 40 feet, the waste temperature criterion limits the maximum allowable canister diameter to 10.8 inches.

The canister design constraints in a shale repository are shown in Figure 3-11. As discussed in Section 2.2.2, 1acking definitive data on shale temperature limits, the maximum allowable waste temperature is, assumed to be the only constraint on diameter. It is seen in Figure 3-11 


\begin{tabular}{|c|c|c|c|c|}
\hline CASE & OVERPACK & $T_{\text {WASTE }}$ & $T_{\text {CAN }}$ & $T_{\text {O }}$ PACK \\
\hline 1 & NO & $=700^{\circ} \mathrm{C}$ & $<350^{\circ} \mathrm{C}$ & NA \\
\hline 2 & YES & $=700^{\circ} \mathrm{C}$ & $\because \leq 350^{\circ} \mathrm{C}$ & $<350^{\circ} \mathrm{C}$ \\
\hline 3 & YES & $\leq 700^{\circ} \mathrm{C}$ & $\leq 350^{\circ} \mathrm{C}$ & $\leq 350^{\circ} \mathrm{C}$ \\
\hline
\end{tabular}

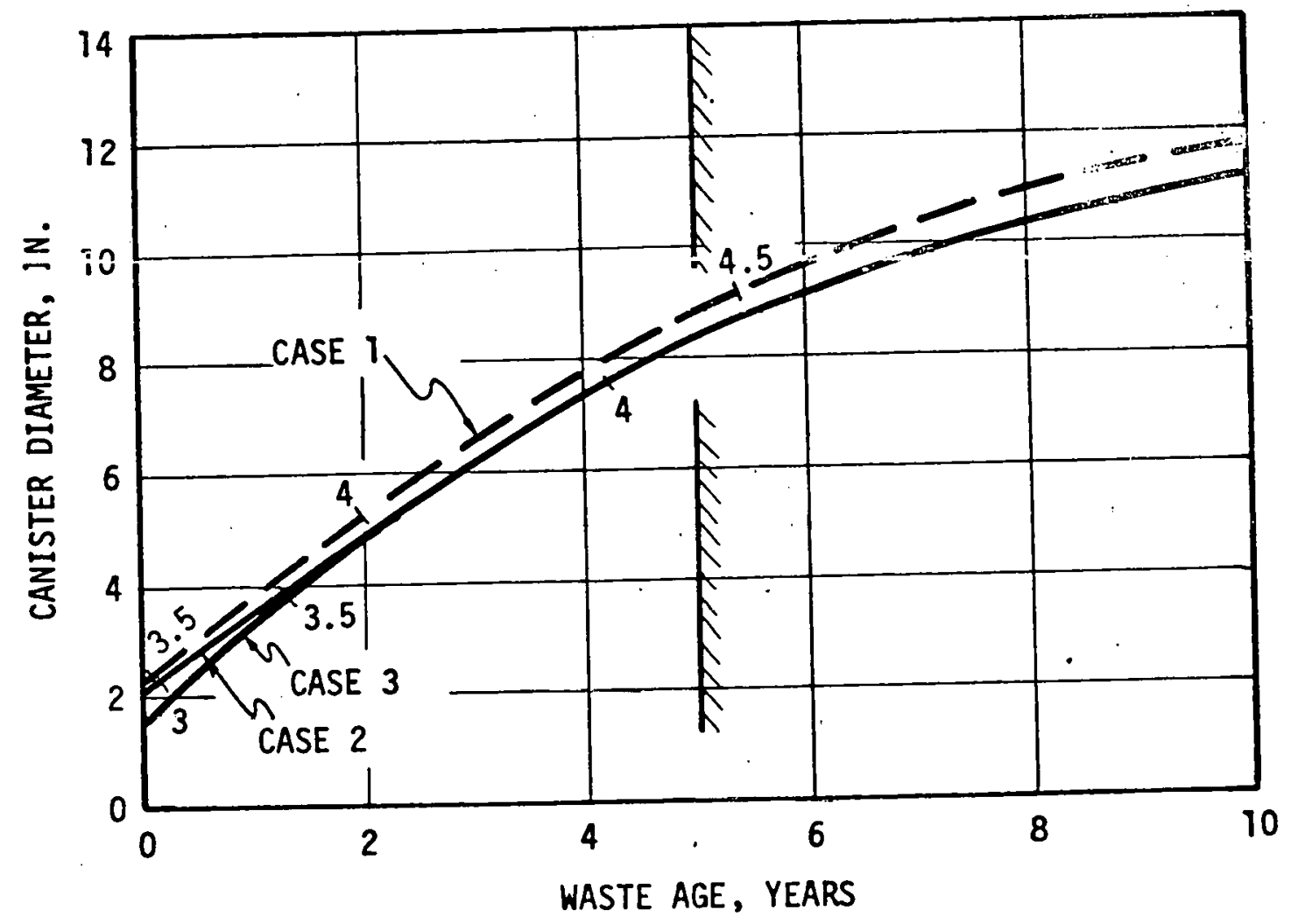

FIGURE 3-9. DESIGN CONSTRAINTS FOR CANISTERS CONTAINING CALCINE WASTE STORED IN AIR-COOLED INTERIM STORAGE 


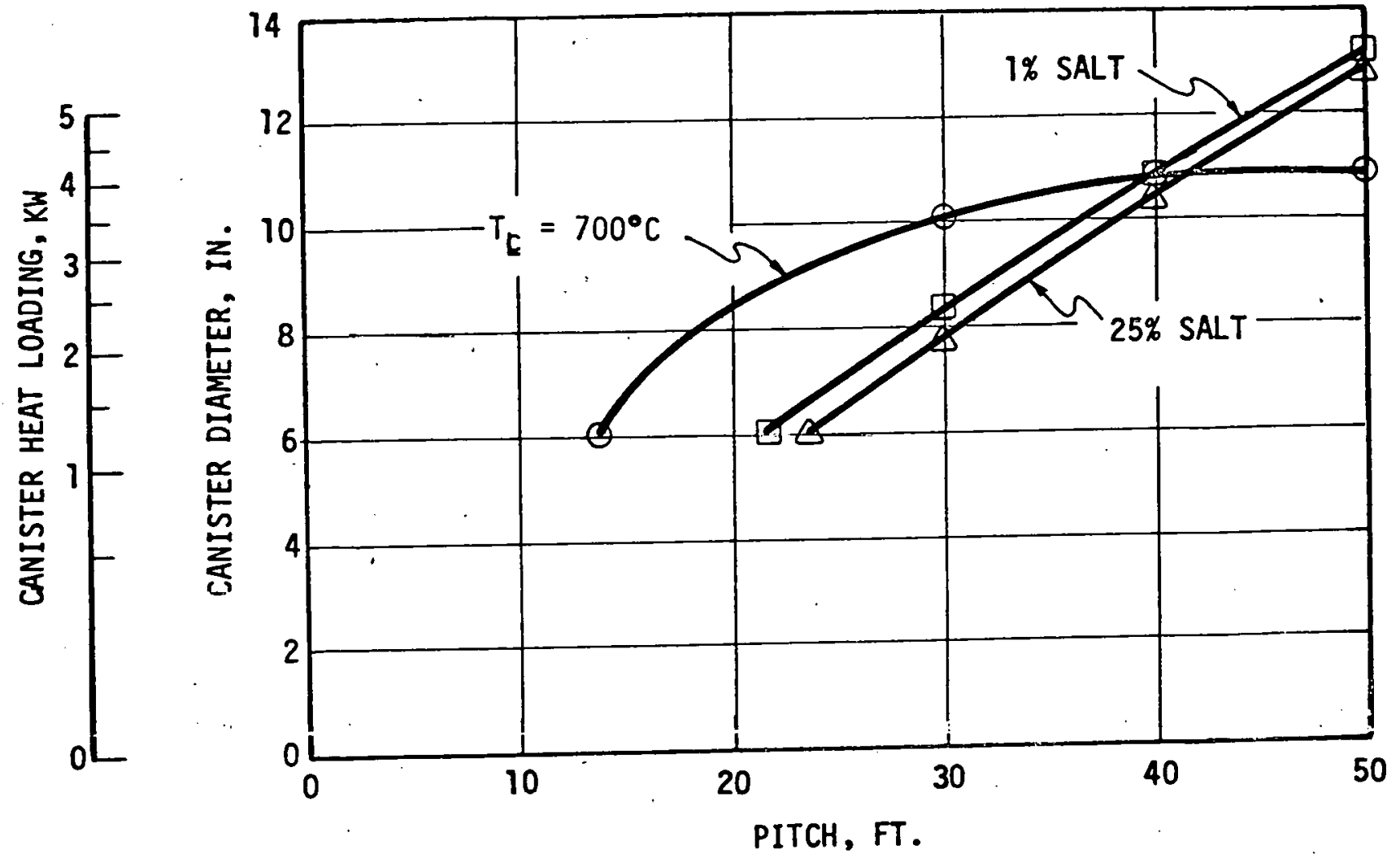

FIGURE 3-10. DESIGN CONSTRAINTS FOR CANISTERS CONTAINING CALCINE STORED IN A SALT REPOSITORY (10-YEAR-OLD PWR WASTE; CANISTER WITH OVERPACK)

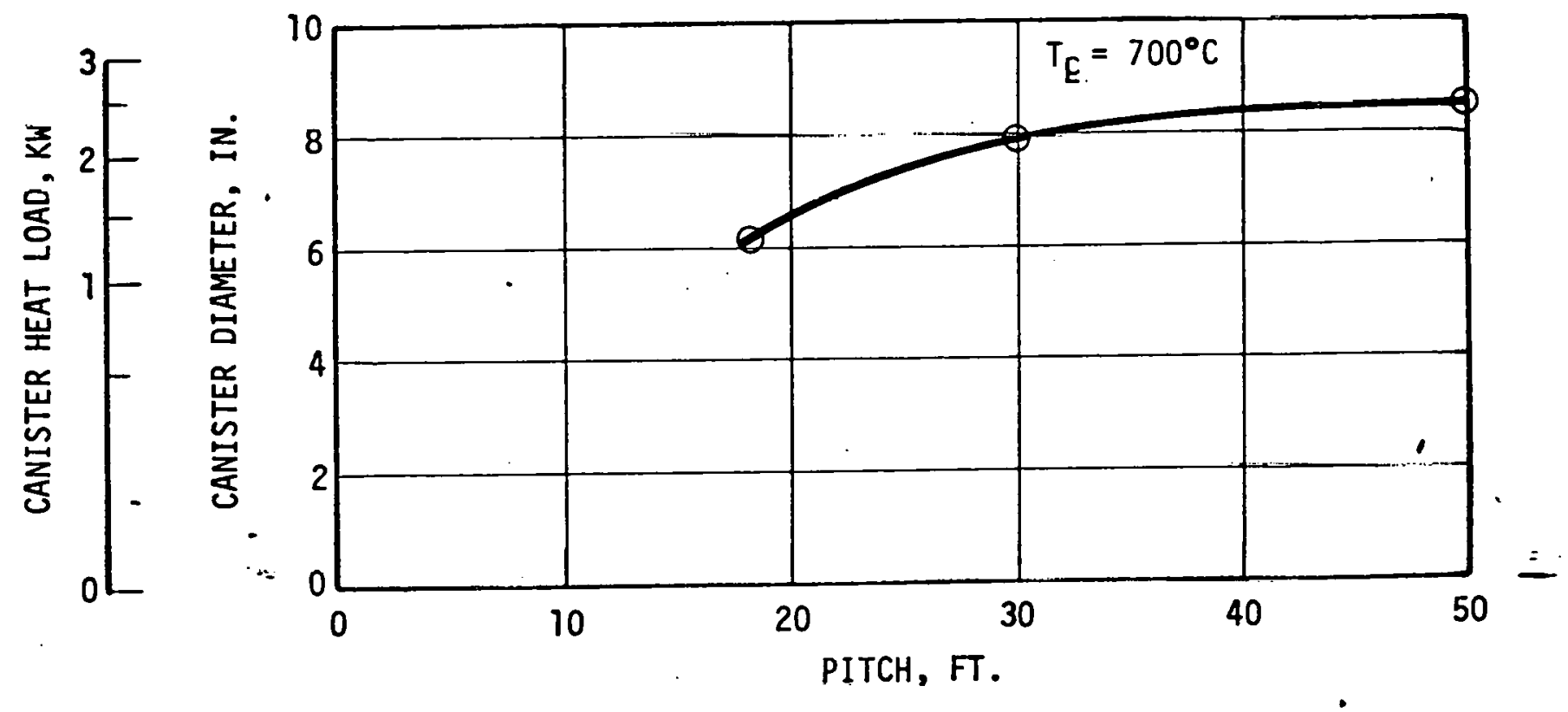

FIGURE 3-11. DESIGN CONSTRAINTS FOR CANISTERS CONTAINING CALCINE STORED IN A SHALE REPOSITORY (10-YEAR-OLD PWR WASTE; CANISTER WITH OVERPACK) 
that the allowable diameter increases slightly with pitch, up to a maximum pitch of 50 feet. The maximum diameter at a pitch of 50 feet or greater is 8.5 inches.

Figure 3-12 shows the results obtained for basalt. Allowable diameter increases with increasing pitch up to a pitch of 30 feet: at 30 feet and greater the diameter cannot exceed 9 inches.
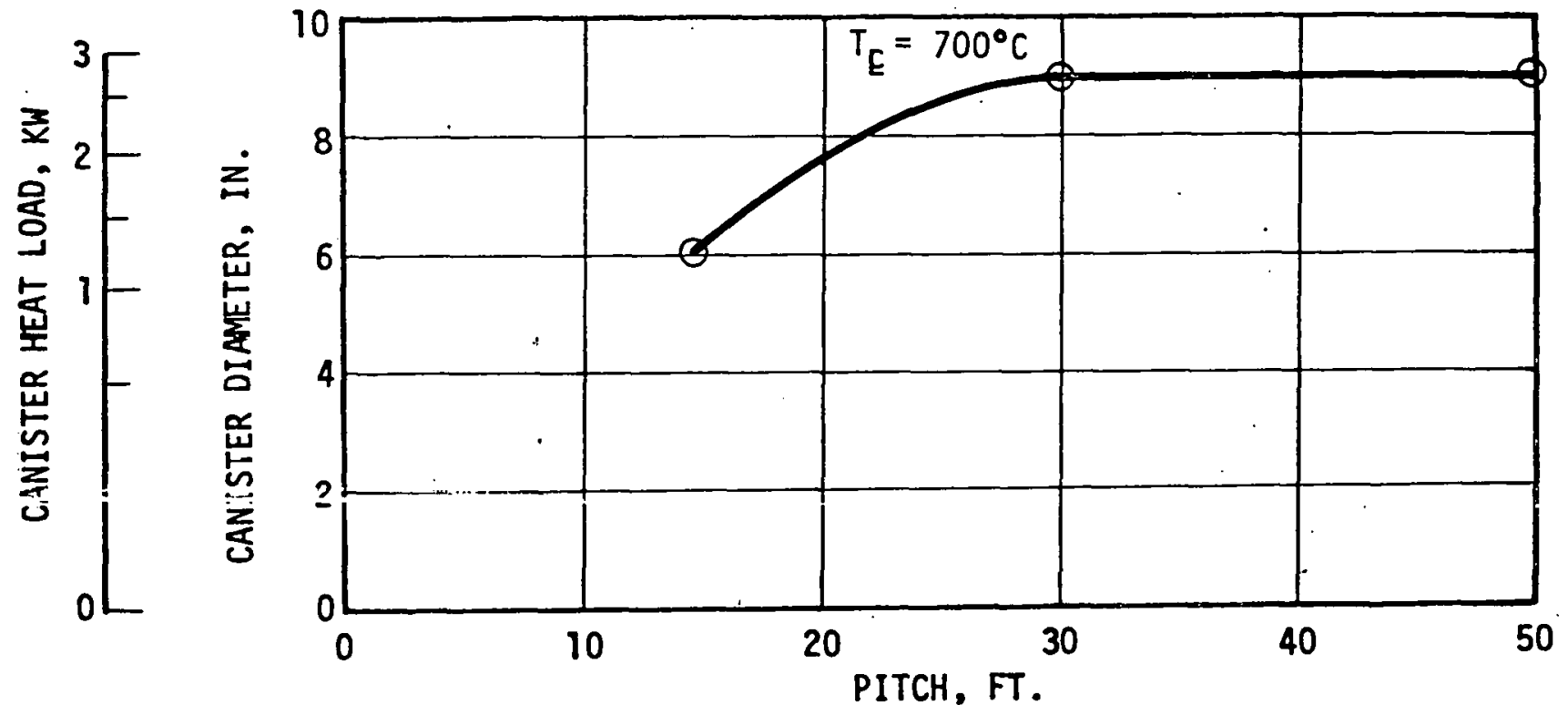

FIGURE 3-12. DESIGN CONSTRAINTS FOR CANISTERS CONTAINING CALCINE WASTE STORED IN A BASALT REPOSITORY (10-YEAR-OLD PWR WASTE; CANISTER WITH OVERPACK)

Calcine-filled canisters destined for geologic storage are thus constrained to maximum diameters of 10.8 inches, 8.5 inches and 9 inches, corresponding to salt, shale and basalt geologic media, respectively.

Figure 3-13 shows the net mine area required for calcine-filled canisters as a function of canister diameter, with the qualification that no temperature limits have been prescribed for shale and basalt. Figure 3-13 shows that, for a repository in salt, there is no benefit, in terms of a decreased mine area requirement, to be derived by using canisters smaller than 10.8 inches in diameter. However, in shale and basalt repositories, there is a mine area advantage associated with using the smallest diameters. Therefore, as described in Section 3.1.2, tradeoffs between variable costs and fixed costs may indicate an optimum canister diameter for shale and basalt. 


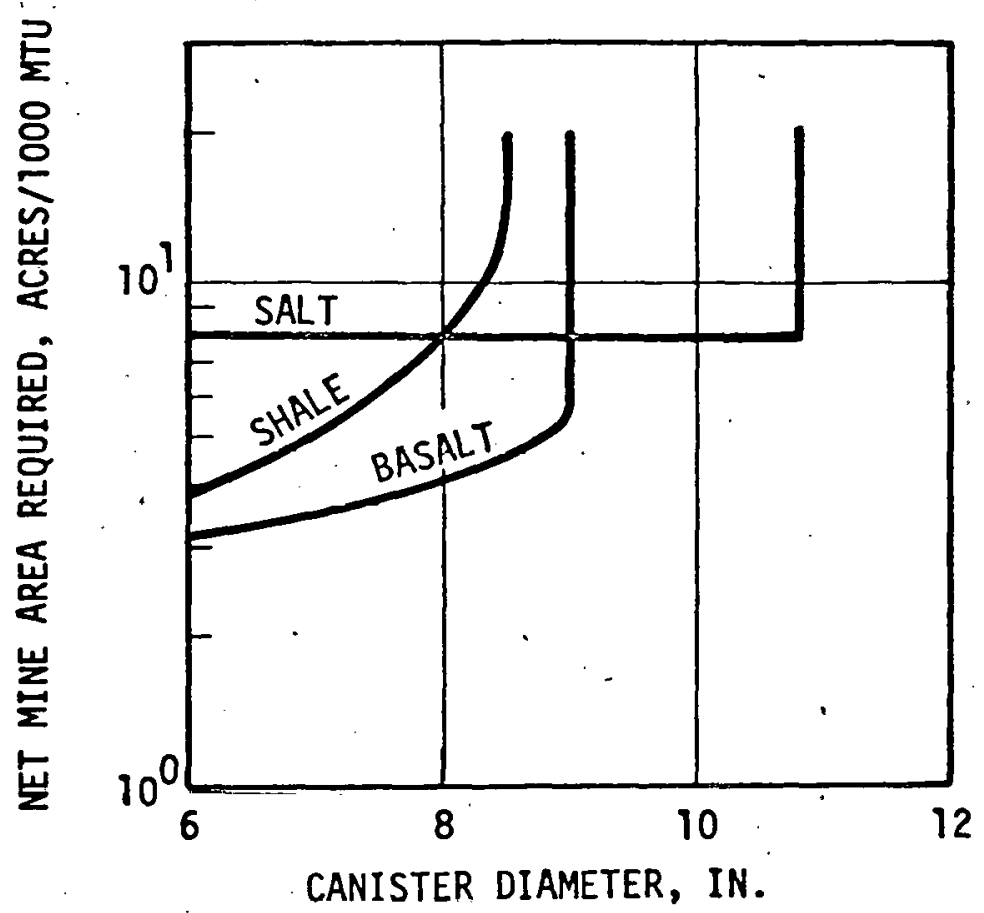

FIGURE 3-13.4 NET MINE AREA REQUIREMENTS FOR OVERPACKED, CALCINE-FILLED CANISTERS

\subsubsection{Summary}

The relatively poor thermal conductivity of calcine and the lower allowable waste temperature constrain the calcine-filled, cylindrical canister diameters and heat loads to values which are less than those allowable for glass-filled canisters.

Because the canister will probably have been sensitized prior to. interim storage, it may be desirable to overpack a calcine-filled canister prior to interim storage. The maximum allowable diameter for any given waste age results from using water-cooled storage. However, even for . water-cooled storage, the maximum diameter which can be used, corresponding to an overpacked canister with 5 -year-old waste, is approximately 9 inches. These results indicate that to use the maximum size which the repository "can accept, the waste will have to be aged for at least 4.5 years. 


\subsection{TEMPERATURE HISTORIES}

Typical temperature histories of the waste, canister, overpack and mine are presented in Figures $3-14^{\star} / 3-15^{\star}$ and $3-16$ for a glass-filled canister in salt, shale and basalt, respectively. In each case the canister diameter is assumed to be 12 inches and the heat load is $2.75 \mathrm{kw}$ at the time it is emplaced at the repository 10 years after reprocessing. The canister is assumed to have the minimum allowable pitch in each respective repository medium. From Figures $3-3,3-4$ and $3-5$ the minimum pitch for a 12-inch diameter canister is 35 feet, 20.4 feet and 26.6 feet for salt, shale and basalt, respectively. The location of the nodes is shown in the sketch on the Figures: Node $a$ is the glass center-line, node $b$ is the canister arrd node $c$ is the overpack. Nodes $d$ and $e$ are at radii which encompass 1 percent and 25 percent of the salt in the unit celi, respectively. Node $f$ is at the radius of the unit cell. The location of nodes $g, h, i$ and $j$ were seiected arbitrariiy to show ine iemijerature history at various locations in the repository.

In a salt repository, as shown in Figure $3-14$, the glass centerline temperature peaks at approximately $320^{\circ} \mathrm{C}$ in about 12 years. The canister and overpack peak shortly thereafter. As shown in Figure 3-3, for a 12-inch diameter canister the constraint is the 25 percent salt criterion (node e). As shown, node e peaks at exactly $200^{\circ} \mathrm{C}$ at approximately 35 years after emplacement. Most of the near-field repository nodes are seen to peak by 45 years, except for nodes $i$ and $j$, located at 43 feet above the room and at the earth's surface, respectively.

In shale, the canister is designed for a maximum centerline temperature of $800^{\circ} \mathrm{C}$. As shown, the centerline temperature (node a) peaks at $800^{\circ} \mathrm{C}$ at approximately 18 years. Mine temperatures are still increasing at 36 years, due to the poor conductivity of the shale.

Figure 3-16, for basalt, similarly shows the waste centerline peaking at $800^{\circ} \mathrm{C}$, -at about 28 years.

* Small inflections in these figures are due to changes of time steps. 

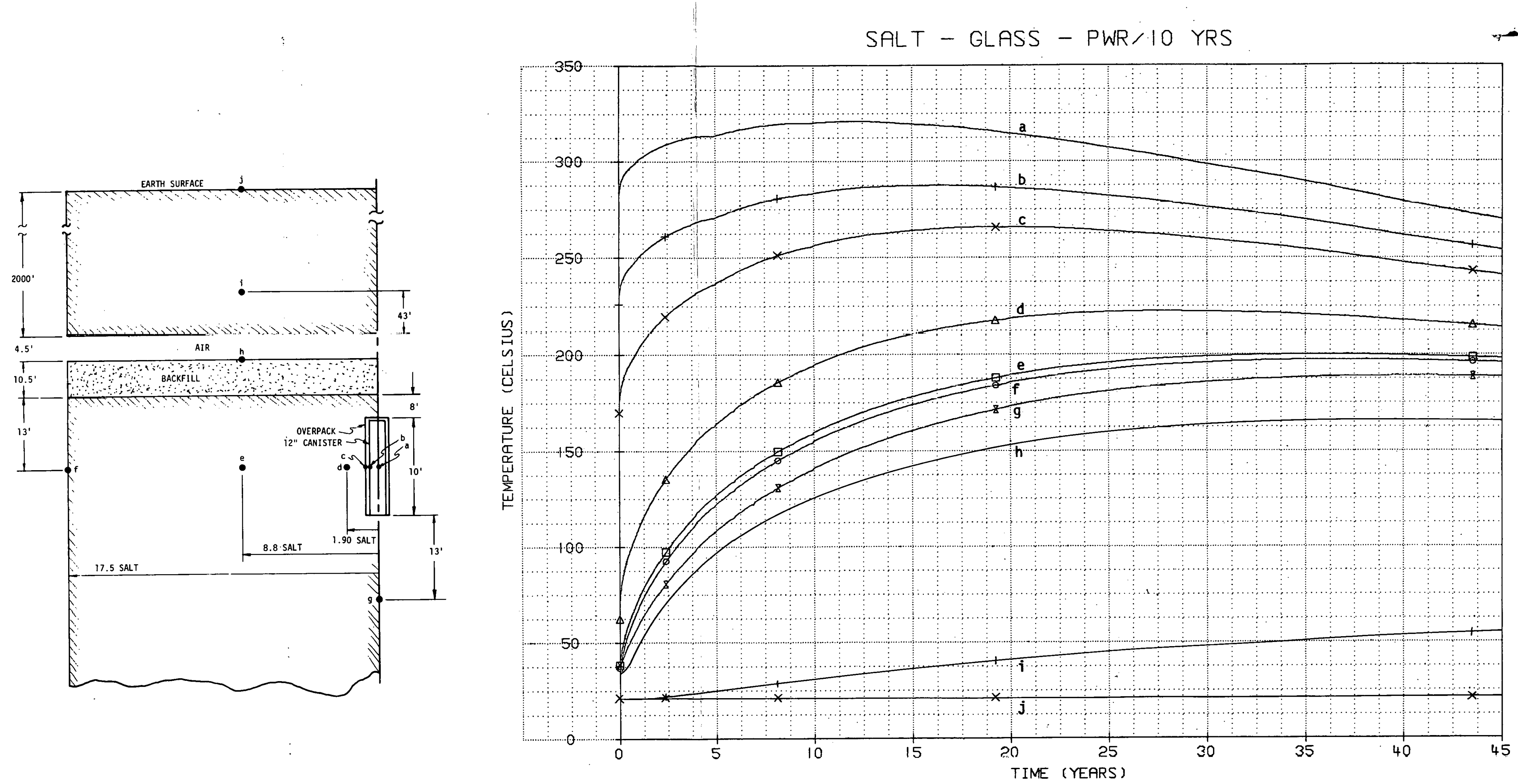

FIGURE 3-14. Temperature History in Salt Repository

(12-inch Diameter Canister; Overpacked;
Glass Waste). 

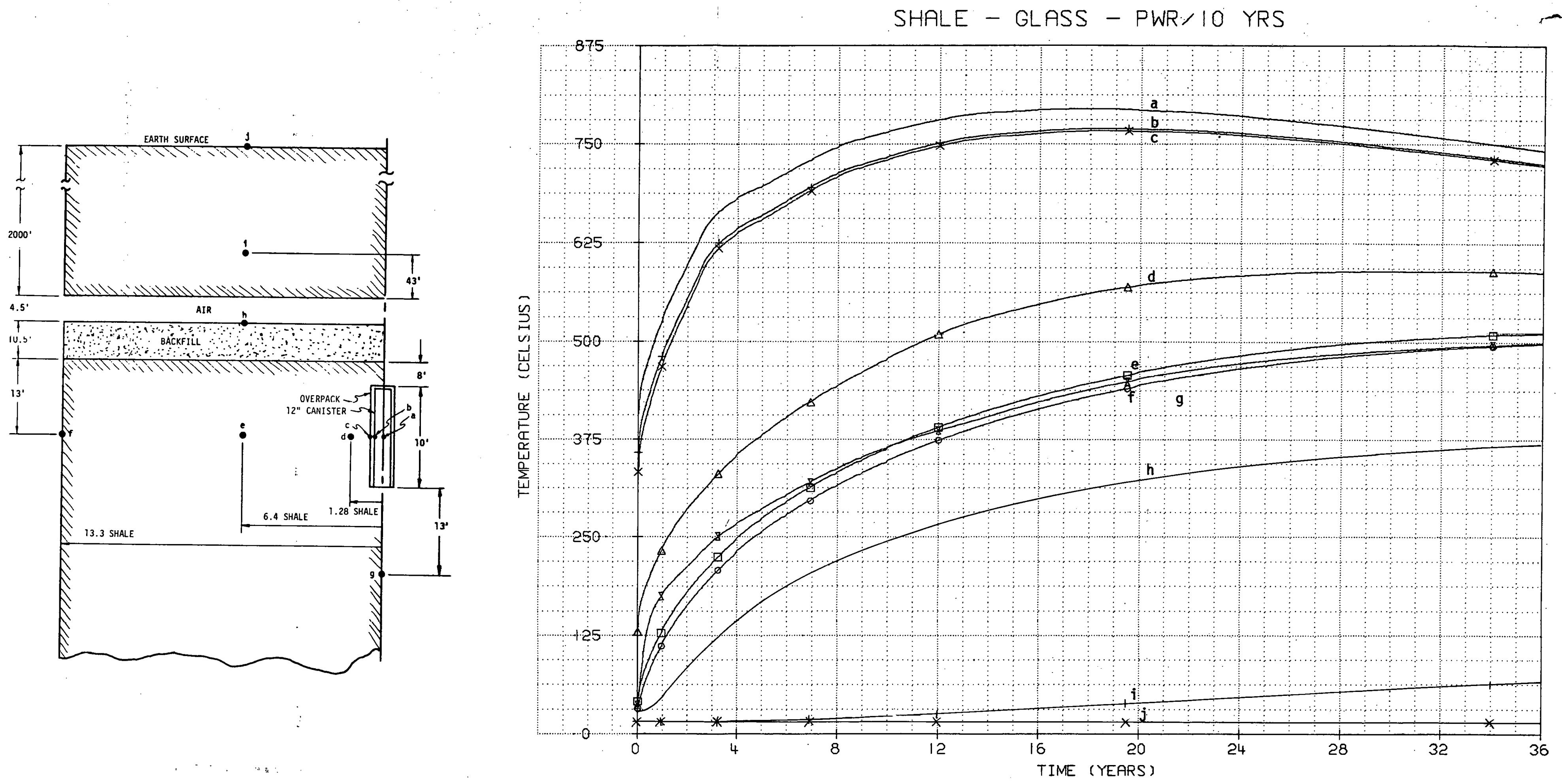

FIGURE 3-15. Temperature History in a Shale Repository

(12-inch Diameter
Canister; Overpacke Glass Waste) 

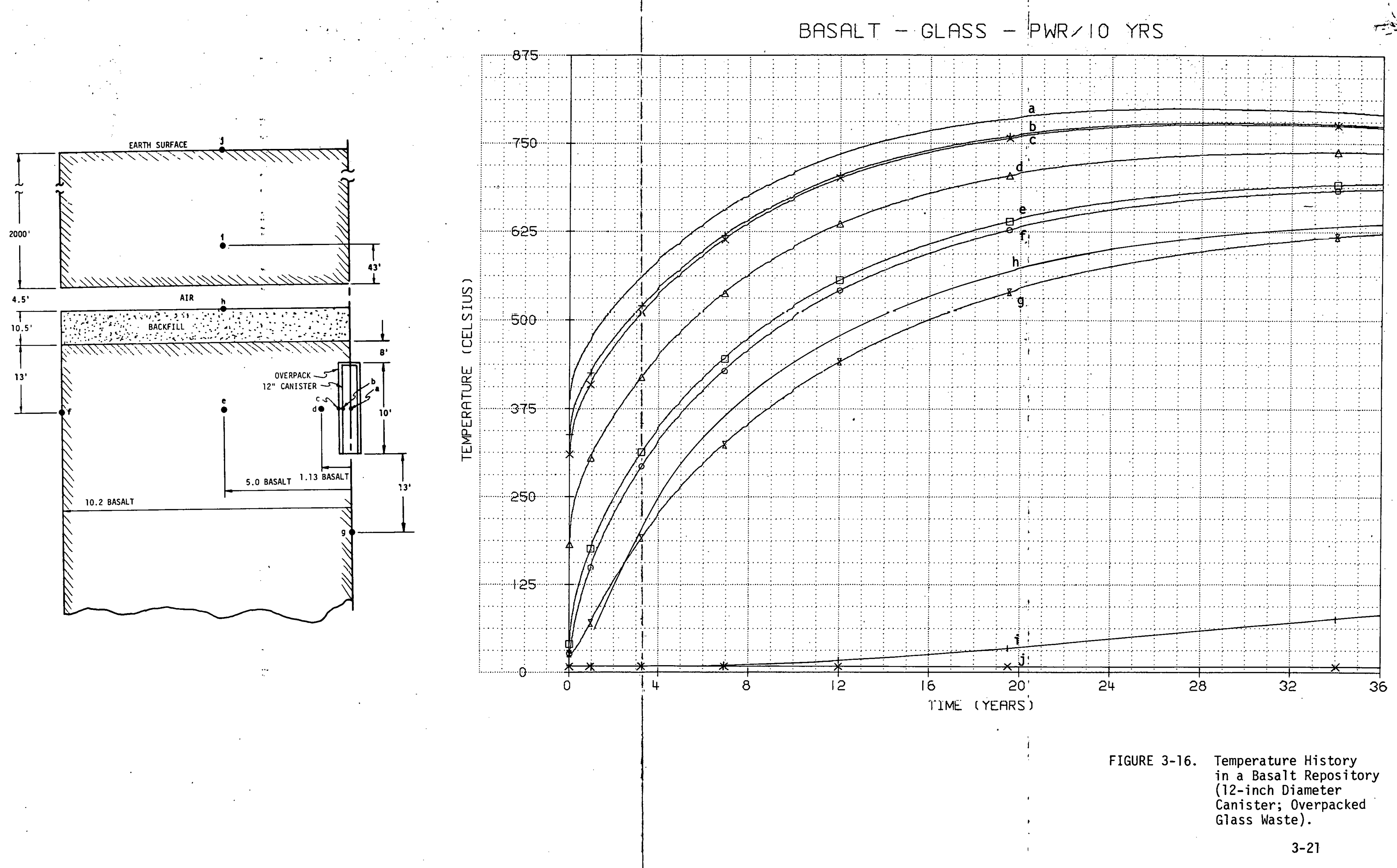


\subsection{SENSITIVITY OF DESIGN CONSTRAINTS}

In this section the effect on the design constraints of alternate cases is investigated. These alternate cases represent potential changes to the baseline cases described in Section 2. Typical effects are presented.

\subsubsection{Waste Source.}

The baseline case assumed that the canister contains 10-year-0ld PWR. waste at the time it is emplaced in the repository. As seen in Appendix A, the waste generated by reprocessing Boiling Water Reactor (BWR) fuel has a thermal inventory which is approximately 75 percent to 80 percent of PWR waste. For the typical case of a glass-filled canister in a salt repository, Figure 3-17 shows a comparison between the maximum allowable diameter, as a function of pitch, for BWR and PWR waste. As expected, BWR waste is seen to allow for slightly greater diameters.

\subsubsection{Waste Age}

The baseline case assumed that 10-year-0ld PWR waste is received at the repository. Theoretically, waste with almost zero age cculd be received, but 5-year-old waste is probably a lower limit. Figure 3-18 shows the effect of 5-year-old waste on the allowable diameter. As shown, 5 -year-0ld waste requires slightly smaller diameters due to the increased heat output.

\subsubsection{Ambient Air Temperature in Interim Storage}

In Reference 18 the effects of ambient air temperature on the temperatures of canisters in air-cooled interim storage are shown. Even considering a wide range of ambient temperatures, the effects are seen to be negligible.

\subsubsection{Canister Emissivity}

As shown in Reference 17', the canister, emissivity can have a significant effect on the canister and waste centerline temperatures in aircooled interim storage: as emissivity decreases, the canister and centerline temperatures increase. The same trend would be observed in geologic storage with an overpack. However, the emissivity values for oxidized stainless steel used in this study (in the range of 0.7 to 0.85 ) are in 


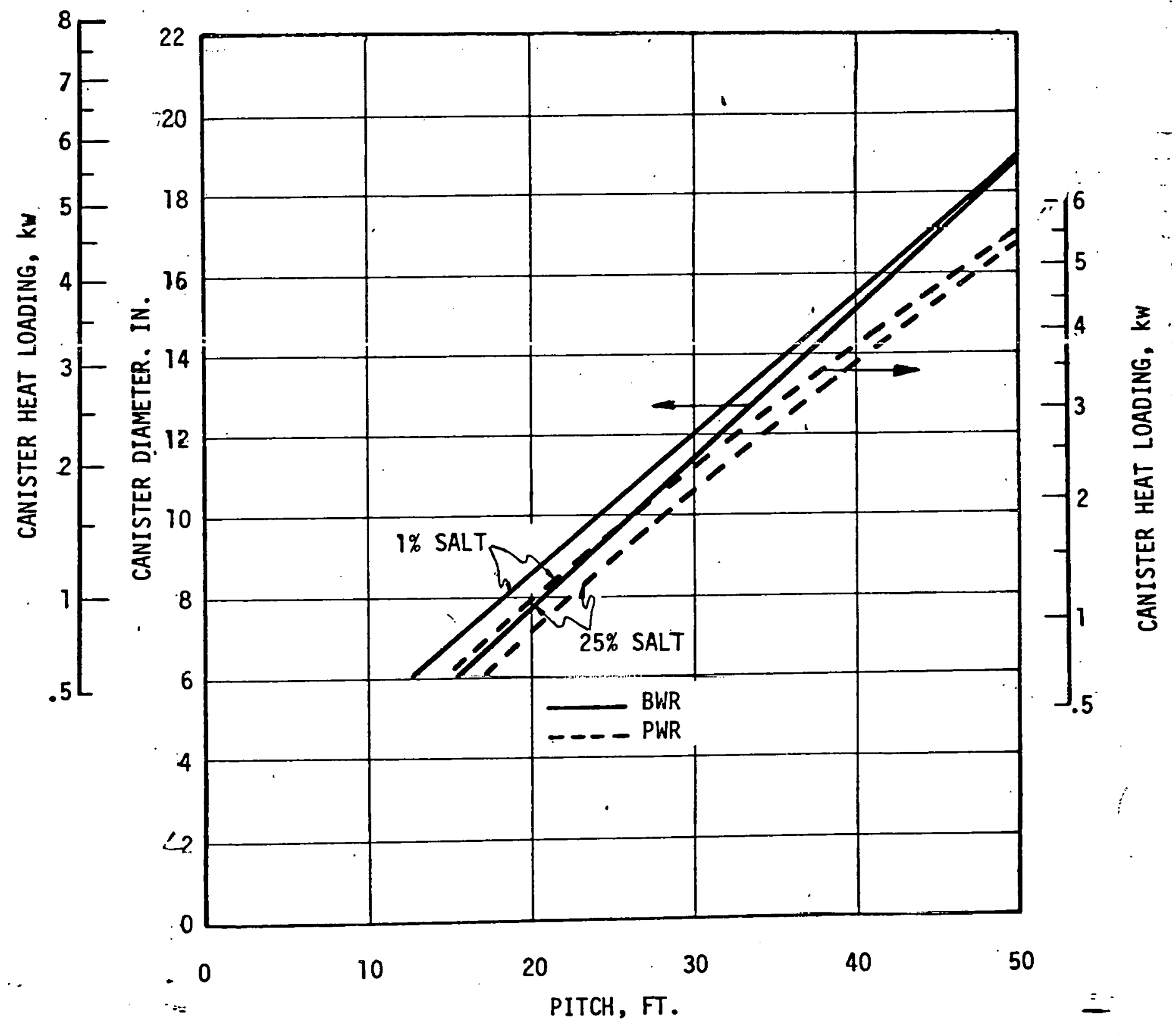

FIGURE 3-17. EFFECT OF WASTE SOURCE ON DESIGN CONSTRAINTS FOR CANISTERS CONTAINING GLASS IN A SALT REPOSITORY (10-YEAR-OLD WASTE; CANISTER WITH OVERPACK) 


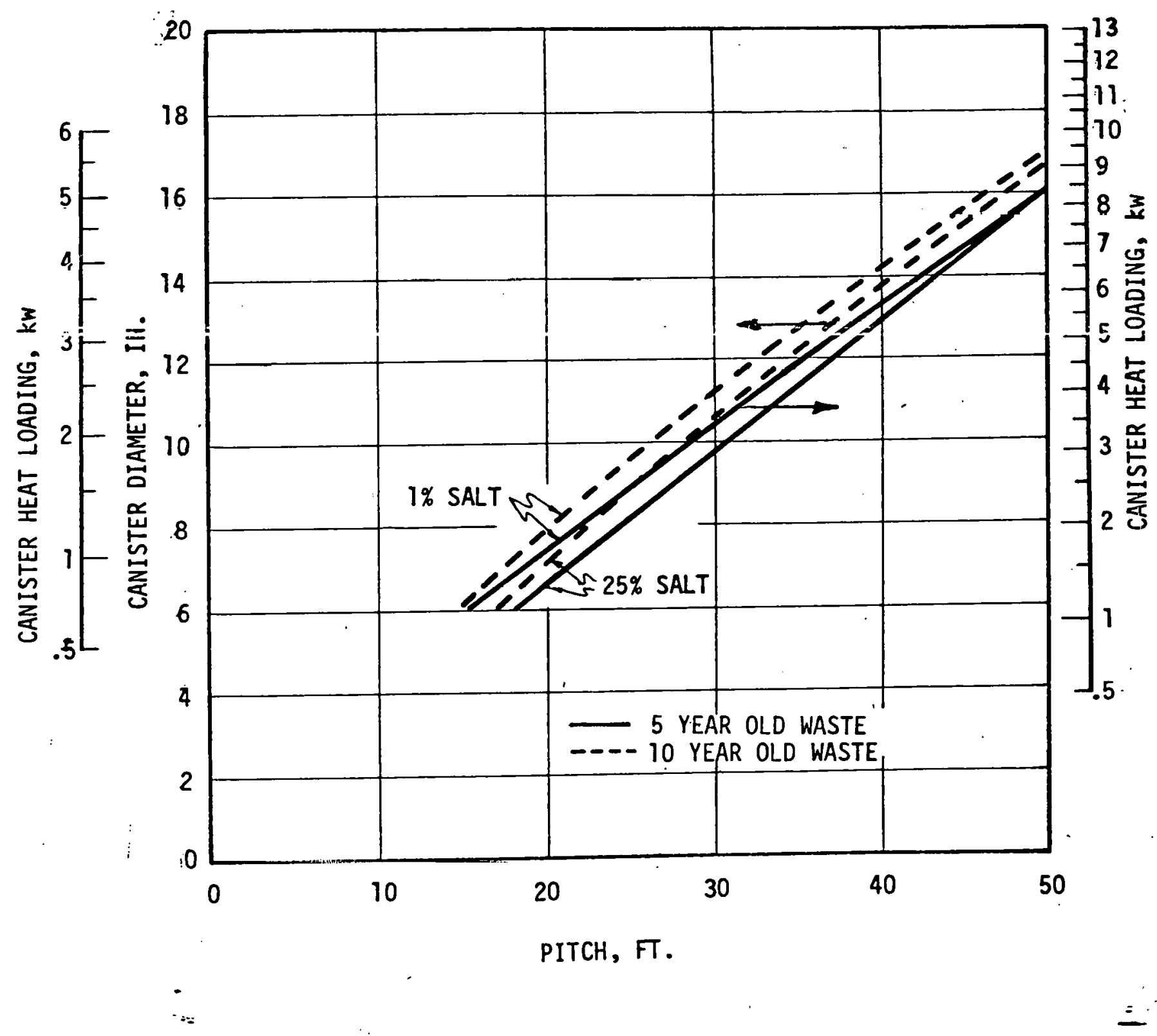

FIGURE 3-18. EFFECT OF WASTE AGE ON DESIGN CONSTRAINTS FOR CANISTERS CONTAINING GLASS IN A SALT REPOSITORY (CANISTER WITH OVERPACK) 
close agreement with values observed (Reference 3 ) following in-can, melting. Therefore, lower values of emissivity do not appear to be realistic.

\subsubsection{Canister/Overpack Backfill}

The baseline cases assumed that the canister closure weld is made in air, thus trapping air between the canister and the overpack. However, as seen in Appendix A, helium has a significantly greater thermal conductivity than air, and could be used to decrease the thermal resistance across the gap. This would allow for slightly larger canisters where the canister surface temperature or the waste centerline temperature is the dominant constraint. In Figure 3-19 the effect of a helium-filled gap

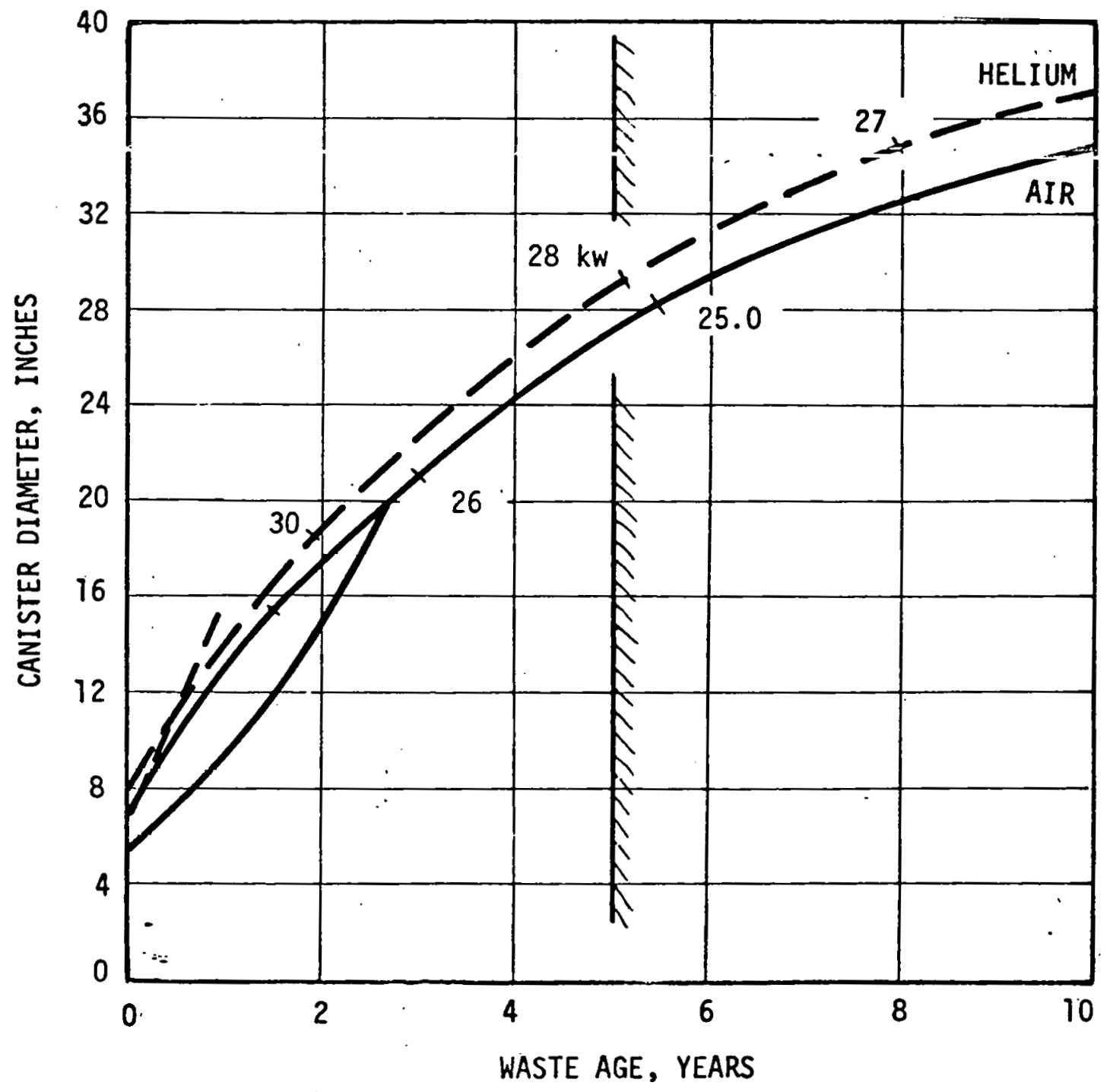

FIGURE 3-19. EFFECT OF OVERPACK BACKFILL ON THE ALLOWABLE DIAMETER AND HEAT LOADING OF GLASS-FILLED CANISTERS IN WATER-COOLED INTERIM STORAGE 
on the allowable diameter of an overpacked, glass-filled canister in water-cooled interim storage is shown. An increase of up to 2 inches can be gained for waste aged 5 years. Likewise, similar advantages would result for air-cooled, overpacked glass canisters in interim storage and overpacked, calcine-filled canisters in either water-or air-cooled interim storage. In geologic storage, a helium backfill would only be of benefit if it can be assured that the overpack remains leak-tight for an indefinite period of time.

\subsubsection{Mine Backfill}

The baseline cases for salt, shale and basalt assumed that the entire room, and the annulus between the overpack and the hole, are backfilled im-

mediately after the canister is emplaced. This baseline case for basalt is shown as a dashed line in Figure 3-20. If the room is not backfilled, the thermal resistance between the mine floor and ceiling is increased, causing a slight reduction in the allowable canister diameter. If neither the room nor the annulus are backfilled, the allowable canister diameter is increased. This results from the heat transfer across the gap. When the annulus is backfilled, heat transfer is by conduction through crushed basalt. Without an annulus backfili, heat transfer is by free convection and radiation. The thermal conductivity of crushed basalt is sufficientiy low that it creates more of a thermal resistance than an air gap. The optinum configuration for basalt, therefore, may be to backfill the room but not the annulus. This trend is only applicable to crushed backfill with low thermal conductivity.

\subsubsection{Canister Temperature Constraint}

As described previously, it was assumed for the baseline cases presented in Sections $3.1,3.2$ and 3.3 that the canister is overpacked when emplaced in the repository and that there is subsequently no constraint on the canister temperature. Thus, for the larger canister diameters, canister temperature may be within the regime at which sensitization occurs, $=$ possibly leading to stress corrosion cracking. However, the waste must be retrievable for a period of 5 years; thus, either the canister, the overpack, or both must remain integral for 5 years to facilitate removal of the waste. If it can be shown that the overpack remains integral in 


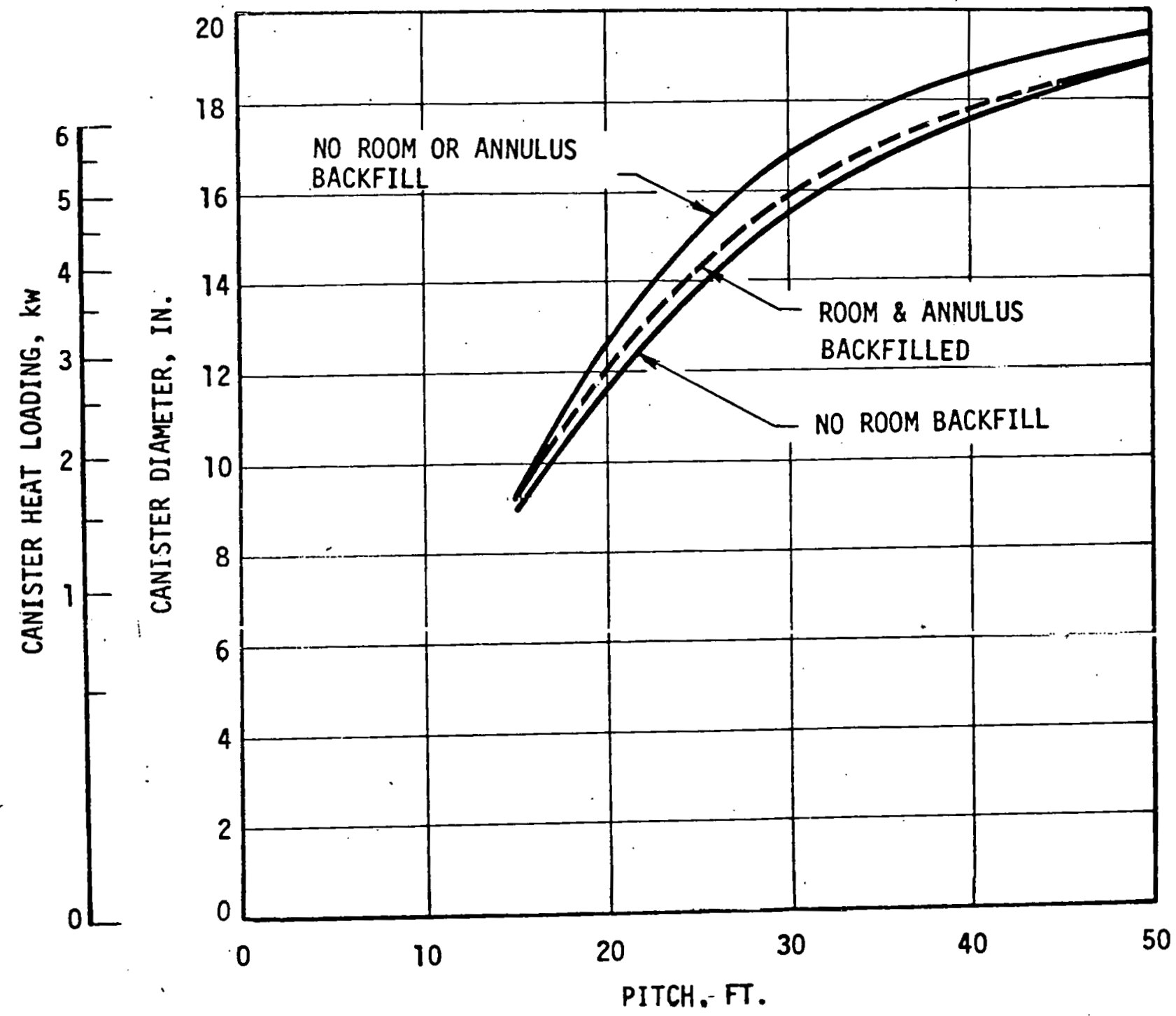

FIGURE 3-20. EFFECT OF BACKFILL ON DESIGN CONSTRAINTS FOR CANISTERS CONTAINING GLASS IN A BASALT REPOSITORY (10-YEAR-OLD PWR WASTE; CANISTER WITH OVERPACK)

the repository media for this period of time, then the assumption of no constraint on the canister temperature is valid. If the overpack integrity cannot be assured, then the canister must be designed to yield a surface tcmperature of $350^{\circ} \mathrm{C}$ or less to preserve its integrity. The effect of this constraint is described below. 
The net effect on the allowable diameters of limiting the canister temperature to $350^{\circ} \mathrm{C}$, for glass-filled canisters in salt, shale and basalt is shown in Figures $3-21,3-22$ and $3-23$, respectively. In salt, this constraint is seen to have an effect only for pitches greater than approximately 48 feet and diameters greater than 16 inches. In shale and basalt, however, this constraint is seen to significantly affect the allowable diameters and heat loads. Large canisters in salt, and all canisters in shale and basalt, are affected because the waste centerline temperature is approximately $800^{\circ} \mathrm{C}$, and the presence of the fins causes the canister surface to have a temperature approaching that of the waste centerline.

Similar results for calcine-filled canisters are shown in Figures 3-24, 3-25 and 3-26. However, because the calcine conductivity is relatively poor, and the centerline is constrained to $700^{\circ} \mathrm{C}$, canister temperature is normally not much higher than $350^{\circ} \mathrm{C}$. In the case of a calcinefilled canister in a sait repository, there is hu effect due to this constraint.

\subsubsection{Calcine Canister Configuration}

As described in Section 3.2, calcine-filled canisters result in small allowable diameters due to the waste centerline temperature constraint and the poor thermal conductivity. Techniques (Reference 14) for allowing enlarged calcine canister diameters and heat loads include dilution of the waste form or the inclusion of an annulus.

Reference 19 describes diluting calcine with sand, yielding a mixture with essentially the same thermal conductivity as calcine, but with lower thermal power per unit volume. This technique can be shown to provide no size advantage when the canister surface temperature is the dominant constraint on diameter. Some advantage may accrue for those cases where centerline temperature is limiting, but this was not further investigated in this study.

Where either the centerline temperature or the canister temperature is the dominant constraint on calcine-filled canisters, an advantage can be gained by providing the canister with an annulus, thus creating a void in the center. The diameter of the inner cylinder can then be a constant, independent of the outside diameter, or the diameter can 


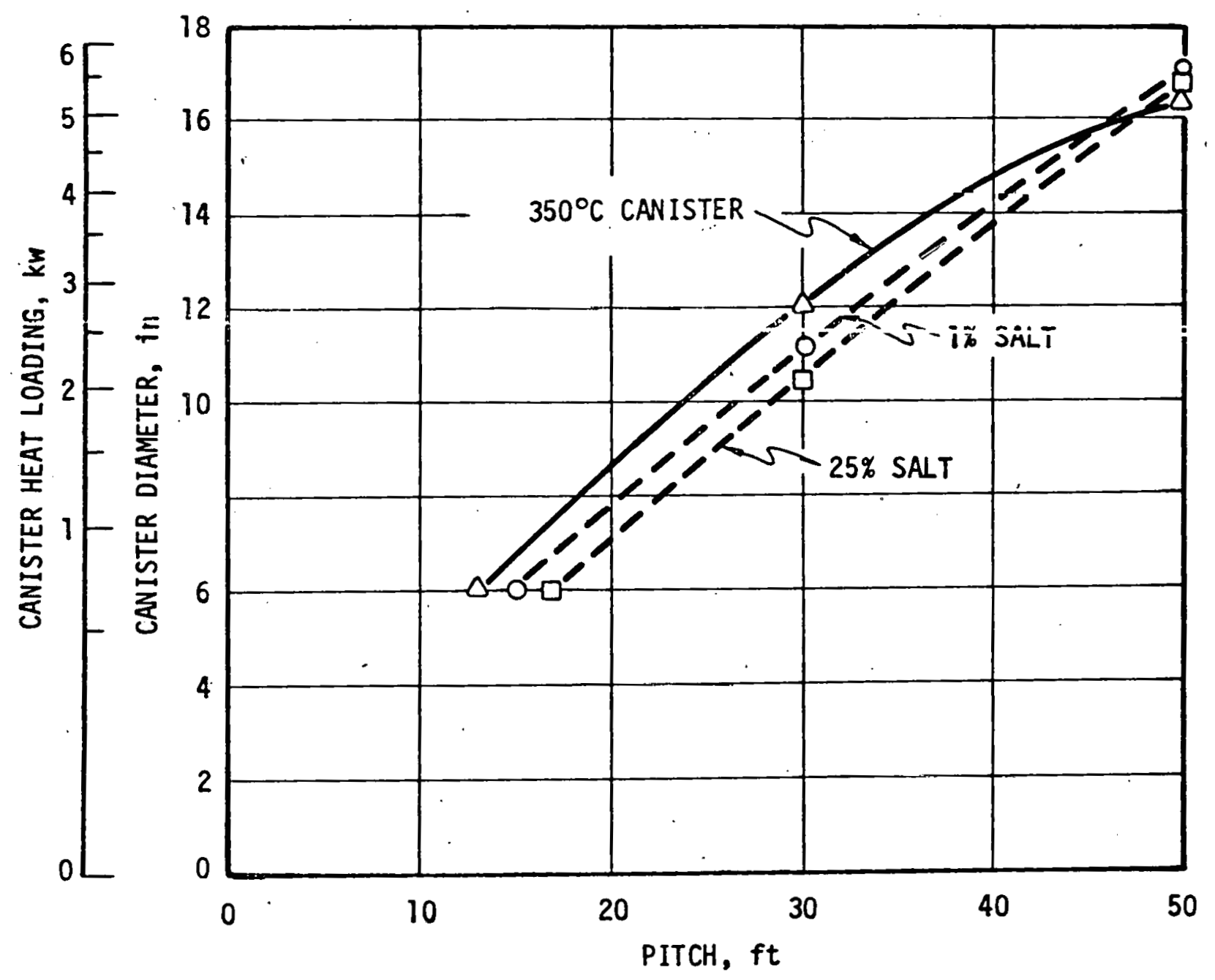

FIGURE 3-21. CANISTER DIAMETER CONSTRAINT INTRODUCED BY LIMITING CANISTER TEMPERATURE TO $350^{\circ} \mathrm{C}$ (GLASS-SALT, 10-YEAR-OLD PWR WASTE; CANISTER WITH OVERPACK) 

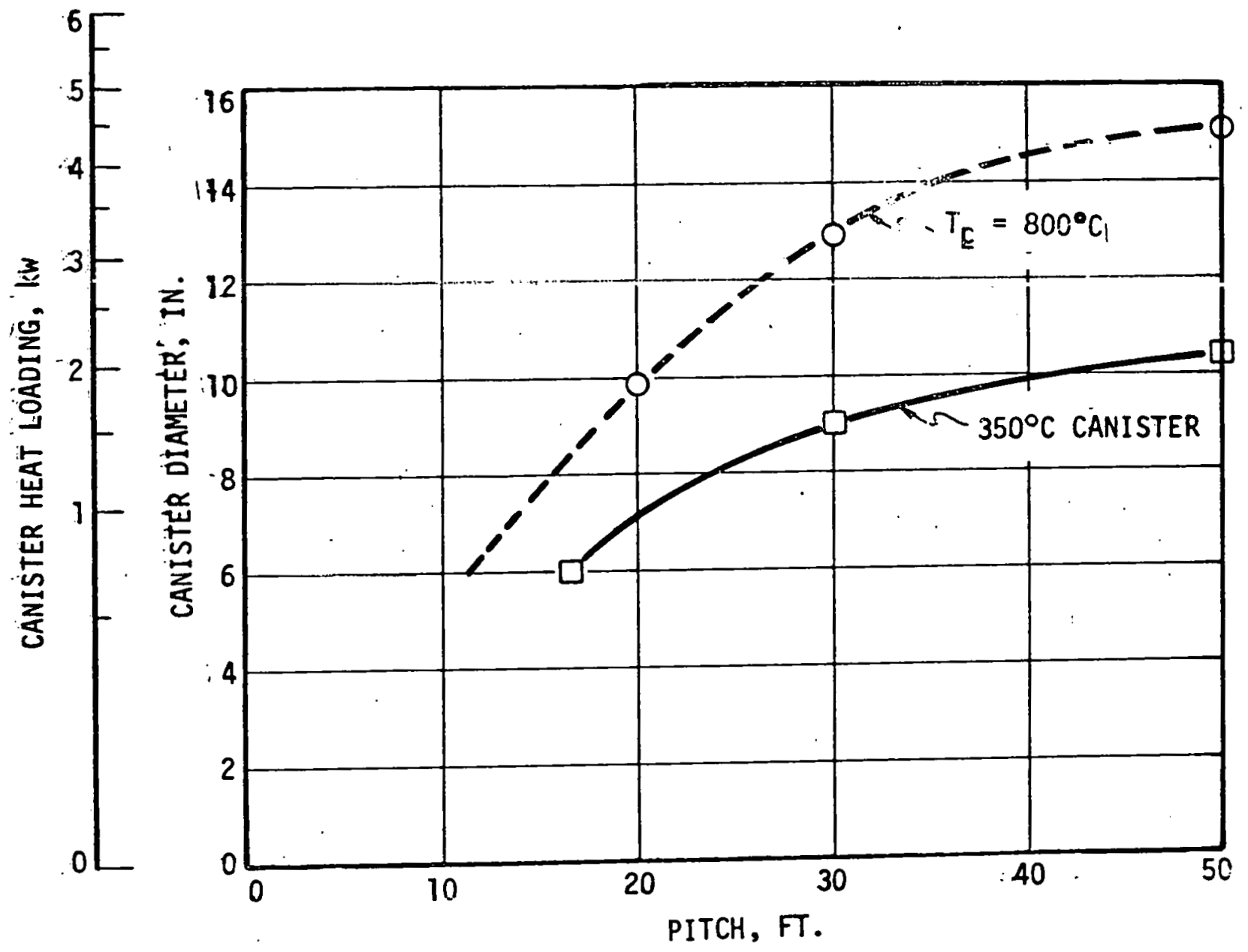

FIGURE 3-22. CANISTER DIAMETER CONSTRAINT INTRODUCED BY LIMITING CANISTER TEMPERATURE TO $350^{\circ} \mathrm{C}$ (GLASS-SHALE, 10-YEAR-OLD PWR WASTE; CANISTER WITH OVERPACK) 


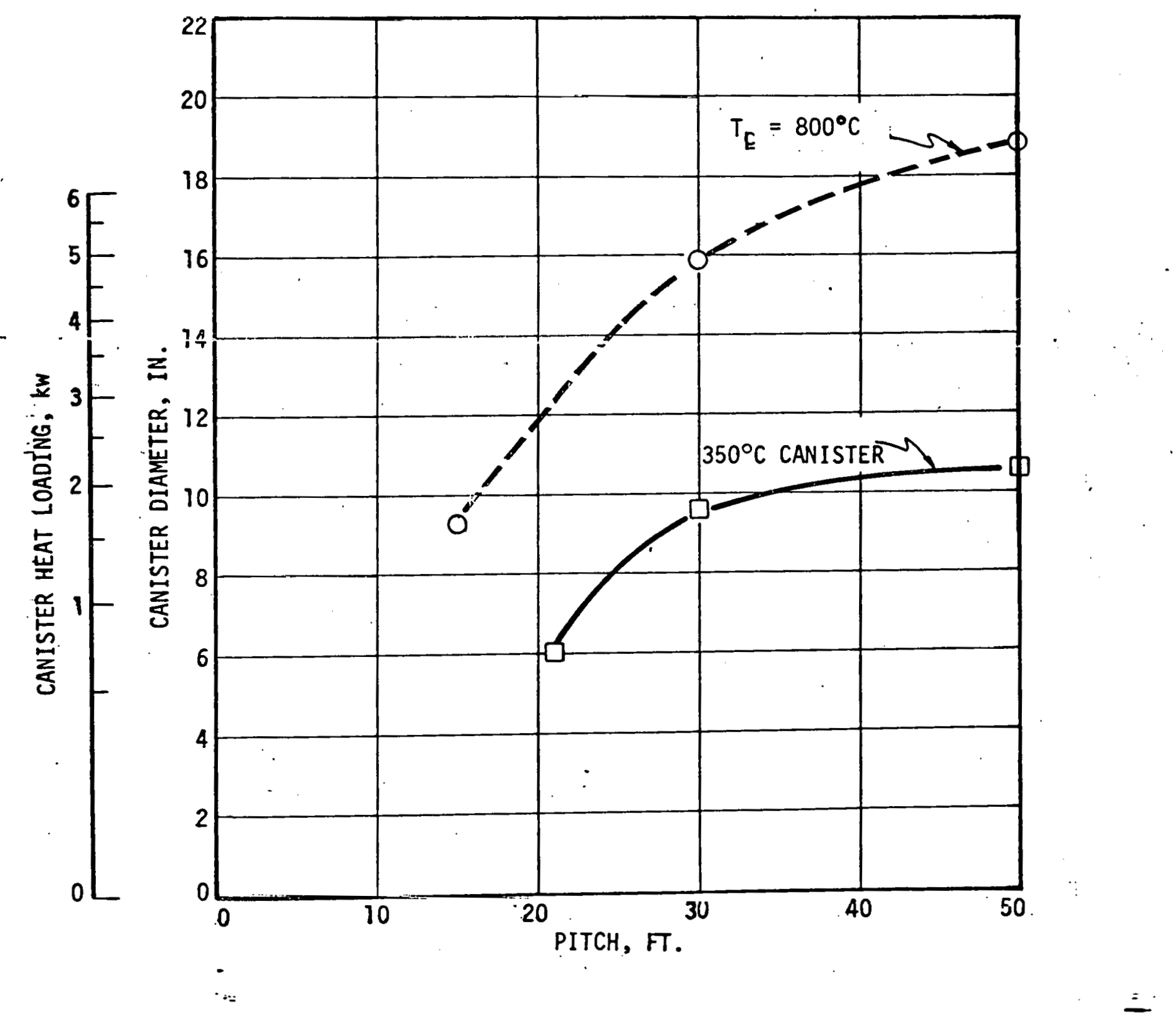

FIGURE 3-23. CANISTER DIAMETER CONSTRAINT INTRODUCED BY LIMITING CANISTER TEMPERATURE TO $350^{\circ} \mathrm{C}$ (GLASS-BASALT, 10-YEAR-OLD PWR WASTE; CANISTER WITH OVERPACK) 


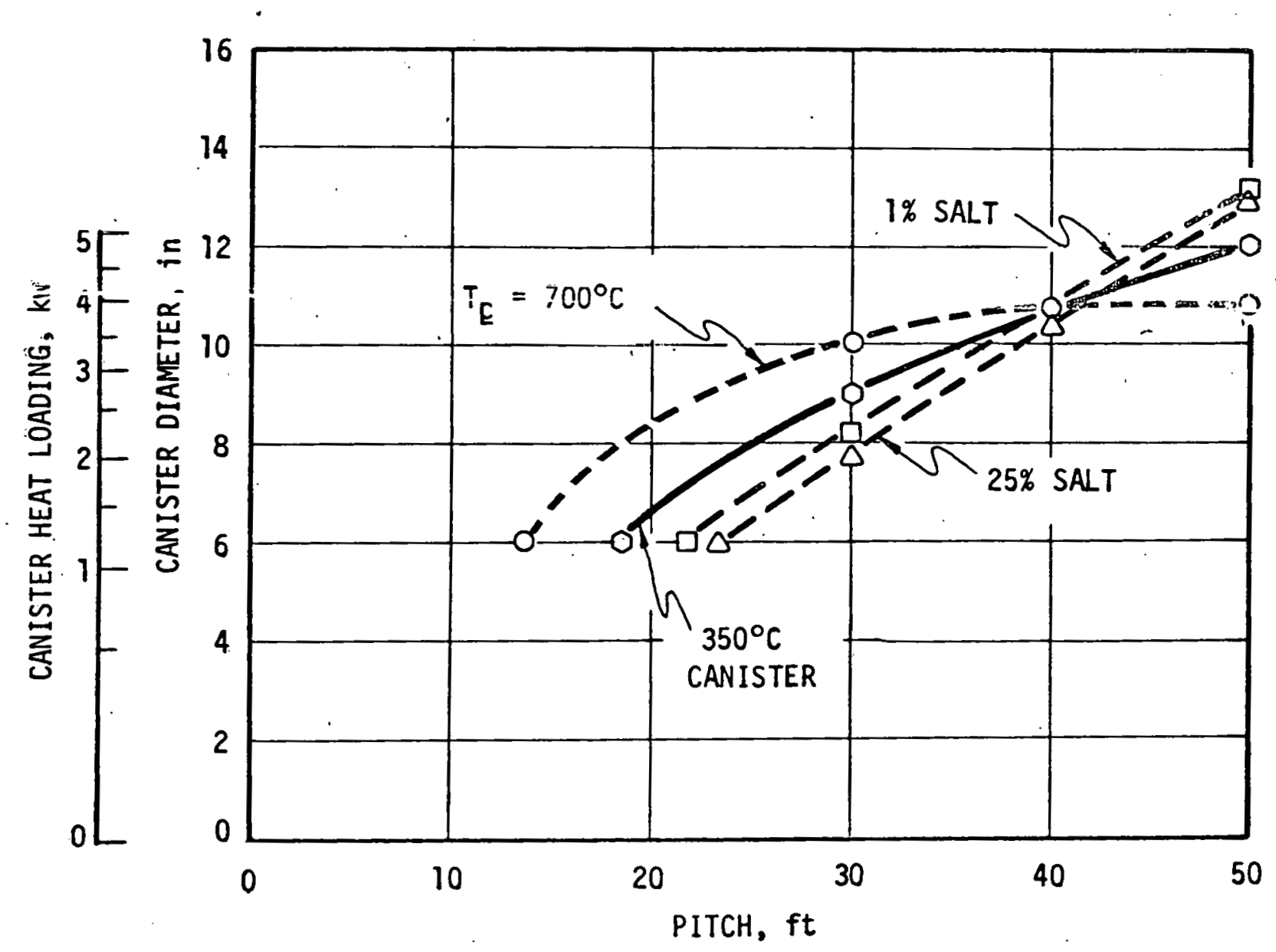

FIGURE 3-24. CANISTER DIAMETER CONSTRAINT INTRODUCED BY LIMITING CANISTER TEMPERATURE TO $350^{\circ} \mathrm{C}$ (CALCINE-SALT; 10-YEAR-OLD PWR WASTE;

$\because$ CANISTER WITH OVERPACK) 


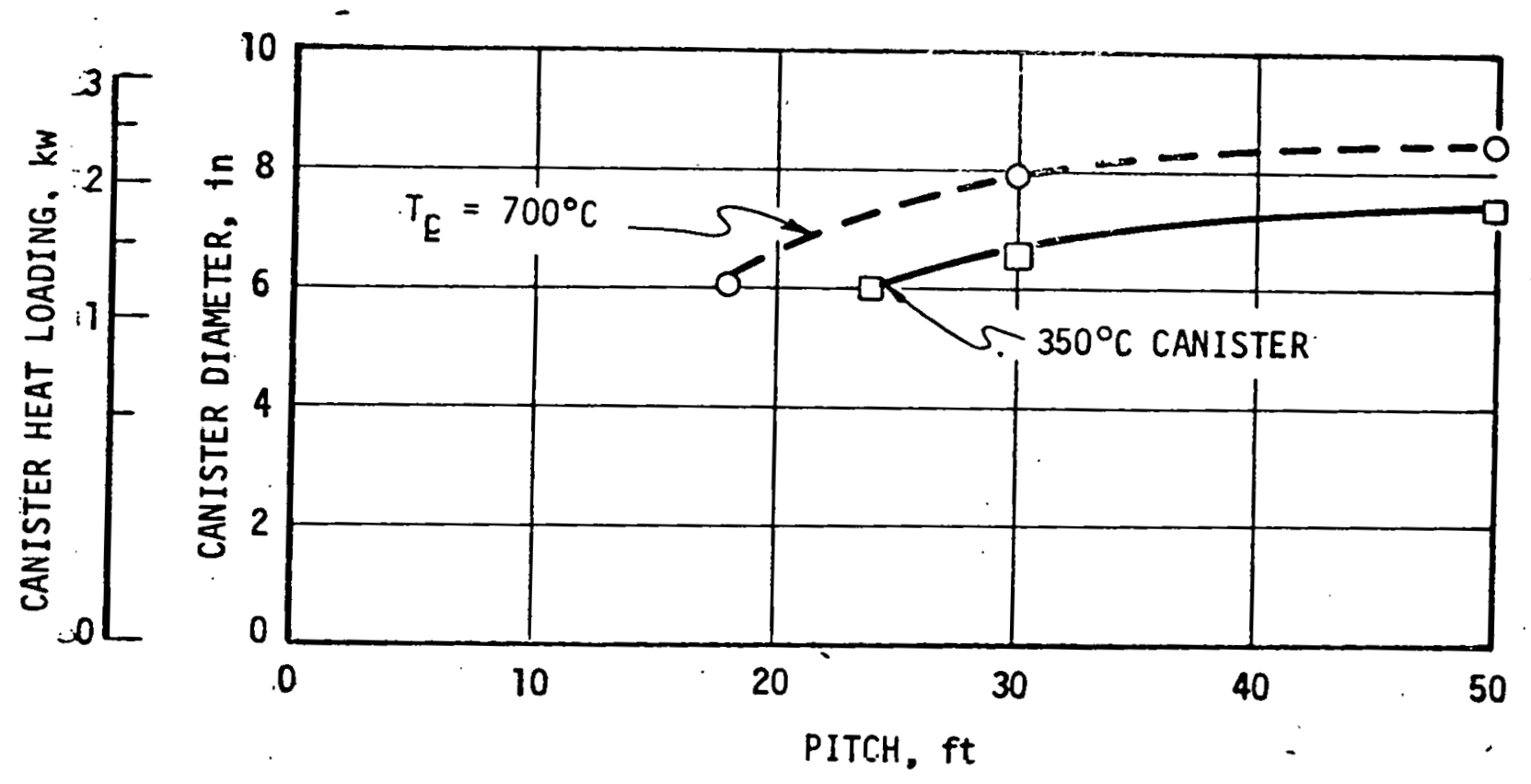

FIGURE 3-25. CANISTER DIAMETER CONTRAINT INTRODUCED BY LIMITNG CANISTLR TEMPERATURE TO $350^{\circ} \mathrm{C}$ (CALCINE-SHALE: 10-YEAR-OLD PWR WASTL; CANISTER WITH OVERPACK)

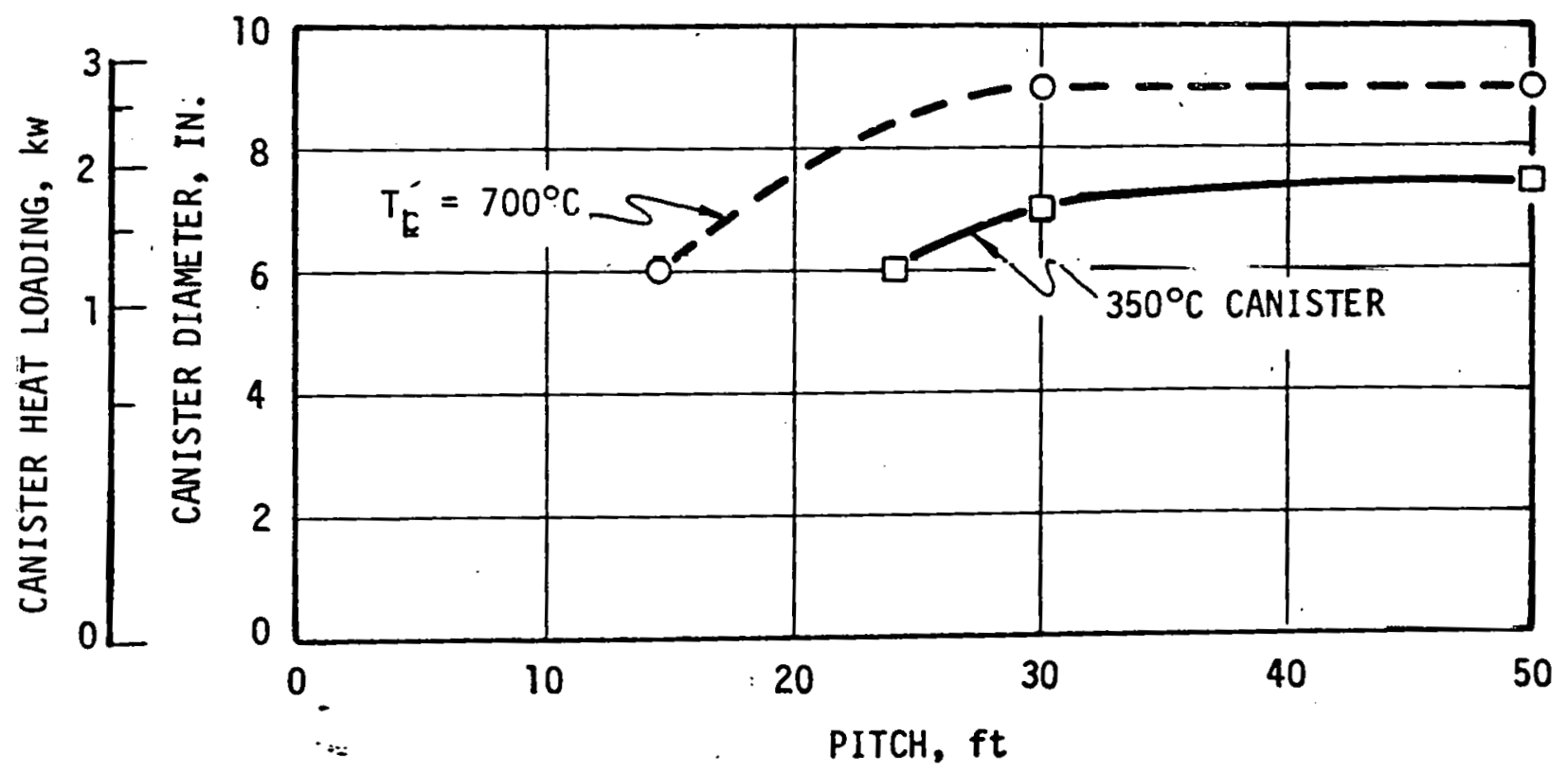

FIGURE 3-26. CANISTER DIAMETER CONSTRAINT INTRODUCED BY LIMITING CANISTER TEMPERATURE TO $350^{\circ} \mathrm{C}$ (CALCINE-BASALT; 10-YEAR-OLD PWR WASTE; CANISTER WITH OVERPACK) 
vary as a function of the outside diameter. To investigate the advantages of an annulus, the inner cylinder was assumed to have a diameter of onehalf the outside diameter.

Very significant increases in allowable diameter and heat load result for annular, calcine-filled canisters in interim storage as shown in Figures 3-27 and 3-28.

Figures 3-29 and 3-30 show the effect of the annulus on the diameters and heat loads allowed for two repository media: salt and shale. Comparison of Figure 3-29 with Figure 3-24 indicates the advantages of the annular cylinder in a salt repository. If calcine center line temperature is the only constraint, the maximum allowable heat loading is increased from $4 \mathrm{kw}$ (Figure 3-10) to approximately $6.5 \mathrm{kw}$ (Figure 3-29). If the canister surface temperature is also a constraint, the maximum allowable heat loading is increased to greater than $5 \mathrm{kw}$. Figure 3-30 shows directly the advantage of the annular cylinder in a shale repository. If the waste center line temperature is the only constraint, the maximum allowable heat loading is increased from approximately $2.4 \mathrm{kw}$ to $3.2 \mathrm{kw}$. Likewise, the annular cylinder allows a maximum heat loading of $1.9 \mathrm{kw}$, compared to 1.8 $\mathrm{kw}$, if the canister surface temperature is the dominant constraint.

\subsubsection{Modeling Approach}

As described in Section 2.2.2, the two-dimensional RZ model used in this study necessarily neglected the walls, or pillars, of the mine room. A comprehensive, three-dimensional analys is is reported by Cheverton, and Turner in Reference 5 for calcine-filled canisters in a salt repository, in which the pillars are included. The results obtained, in the current study can, therefore, be compared with Reference 5 .

There are certain differences, other than the pillars, between the modelling of Reference 5 and the modelling of this study. These differences affect the results obtained.

- bhereas this study assumes a homogeneous medium above and below the mine room, Reference 5 includes shale, layers above and below the mine room, and a mixed shale and salt layer above the mine room. The inclusion of shale will generally increase mine-level temperatures and predict smaller al lowable canister heat loadings, at a given'pitch, because of the poor conductivity of shale in the transiverse direction. 


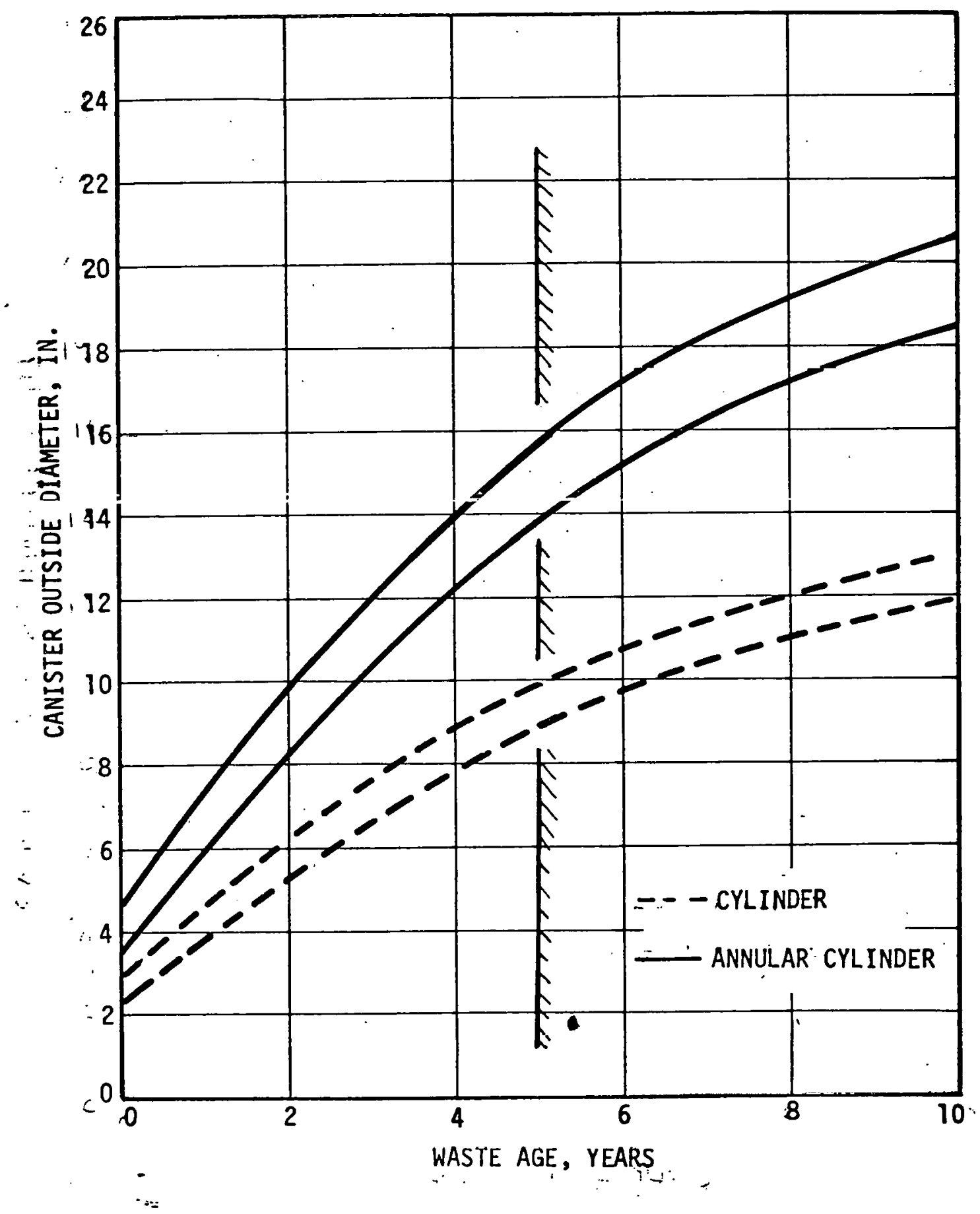

FIGURE 3-27. EFFECT OF ANNULAAR CANISTER ON ALLOWABLE DIAMETER AND HEAT LOADING OF CALCINE-FILLED CANISTERS IN WATERCOOLED INTERIM STORAGE (PWR WASTE) 


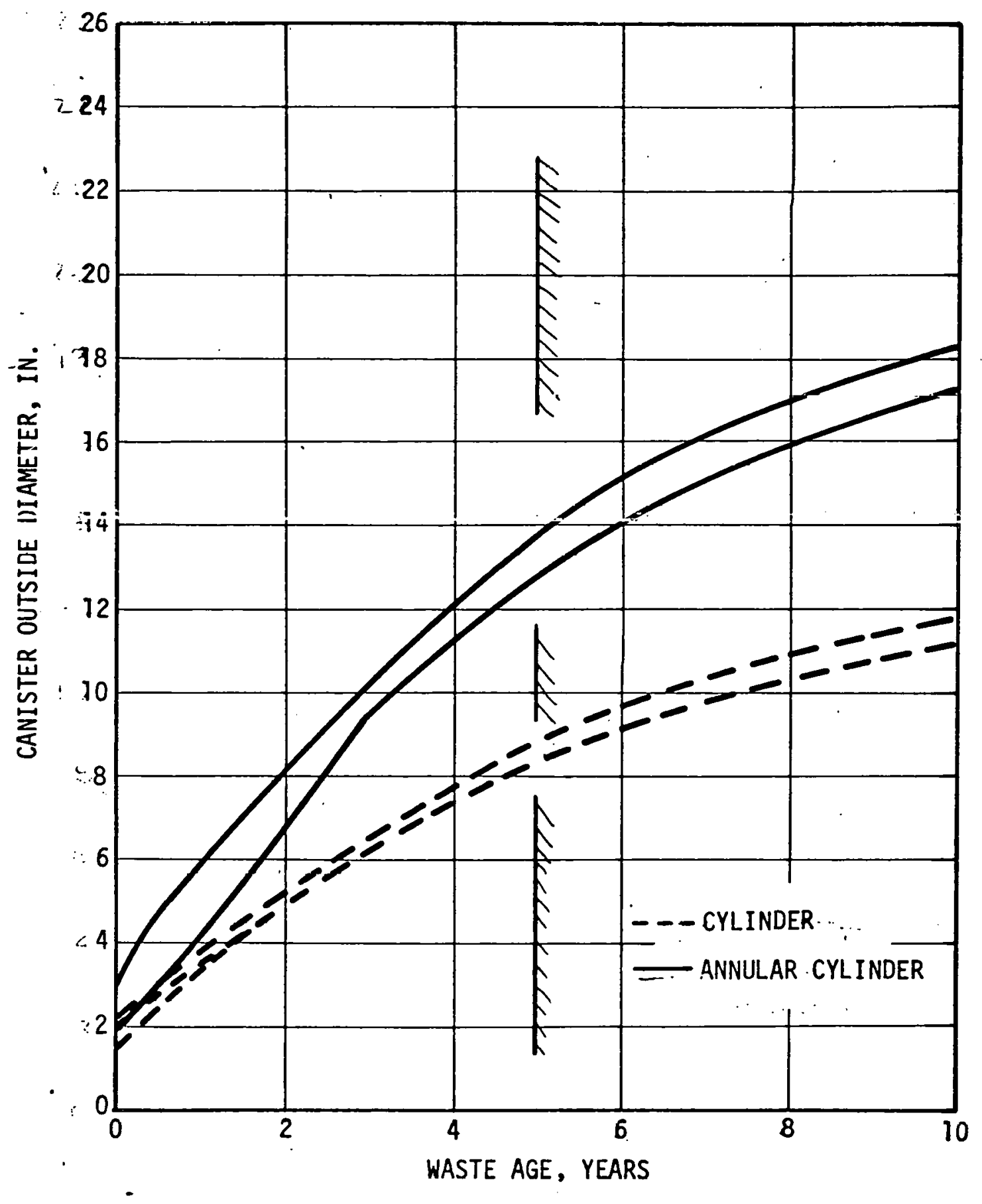

$\cdot \because$

FIGURE 3-28. EFFECT OF ANNULAR CANISTER ON ALLOWABLE DIAMETER AND HEAT LOADING OF CALCINE-FILLED CANISTERS IN AIR-COOLED INTERIM STORAGE (PWR WASTE) 


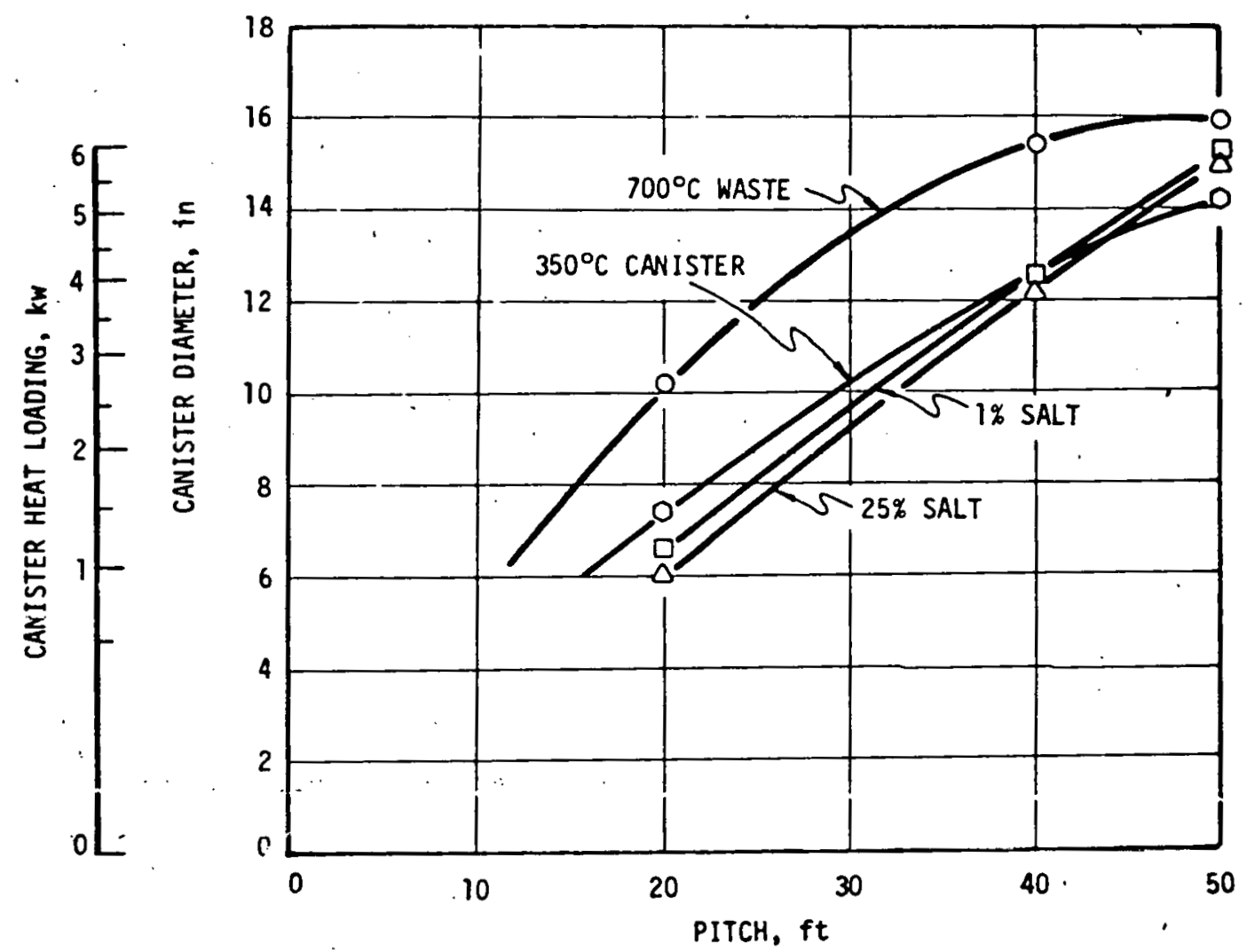

FIGURE 3-29. DIAMETERS FOR CALCINE-FILLED ANNULAR CANISTERS IN A SALT REPOSITORY (10-YEAR-OLD PWR WASTE; CANISTER WITH OVERPACK)

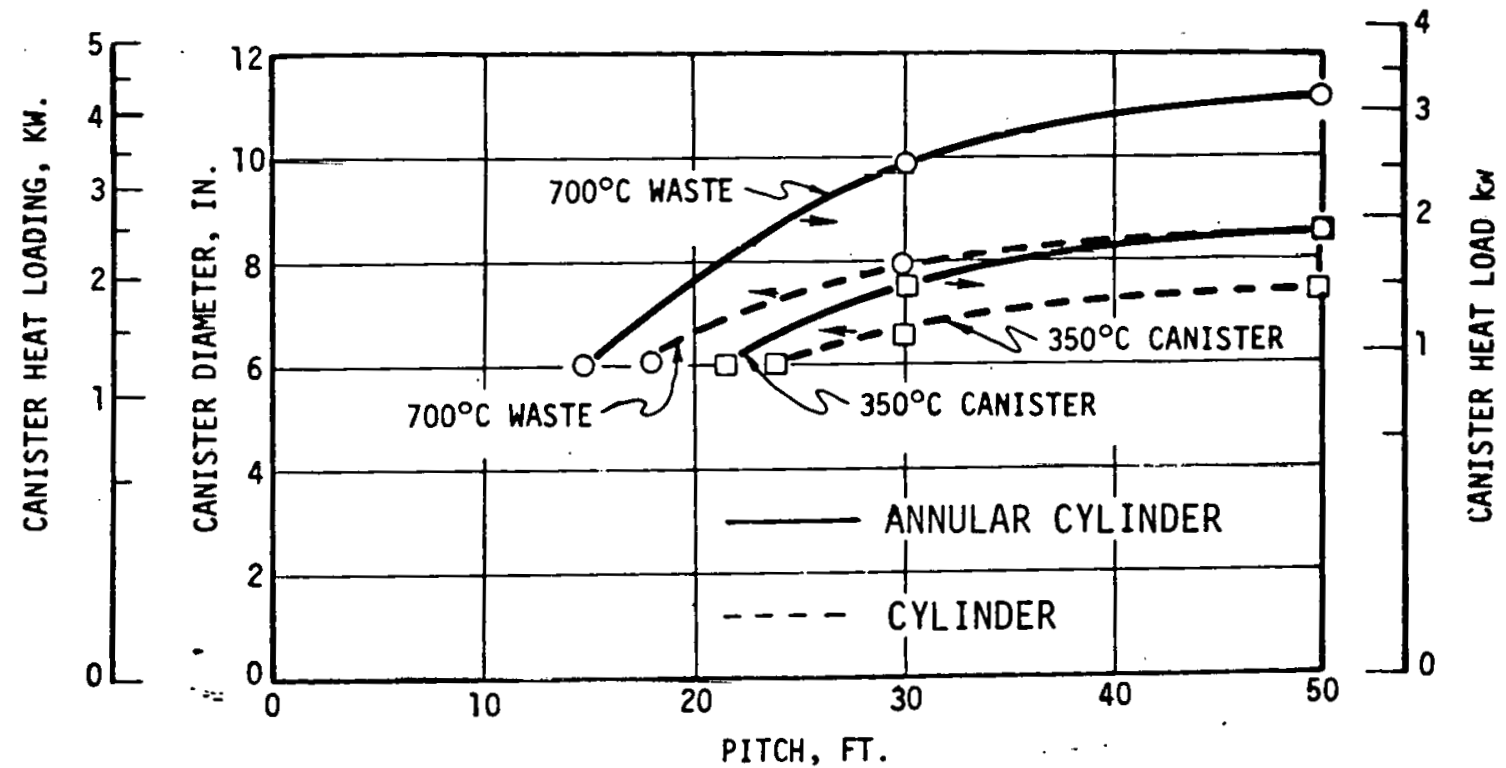

FIGURE 3-30. DIAMETERS FOR CALCINE-FILLED ANNULAR CANISTERS IN A SHALE REPOSITORY (10-YEAR-OLD PWR WASTE; CANISTER WITH OVERPACK) 
- Whereas this study assumes a maximum allovoble temperature of $700^{\circ} \mathrm{C}$ for the calcine, the study reported in Reference 5 assumed a maximum allowable temperature of approximately $600^{\circ} \mathrm{C}$. The lower temperature will cause smaller allowable canister heat loadings for fixed values of pitch.

- A constant calcine conductivity, greater than that used in this study, was used in the Reference 5 study. The higher conductivity will result in larger allowable canister heat loadings for fixed values of pitch.

- The canister configuration examined in Reference 5 does not appear to include an overpack. Deletion of the overpack will result in larger allowable canister heat loadings for fixed values of pitch.

- The canister is assumed in Reference 5 to be filled with waste to a height of 10 feet, whereas this study assumed it to be filled. to only 8 feet. The assumption of a greater fill height probably increases the allowable heat loadings for fixed values of pitch.

For the 15-fnot-wide room. Reference 5 assumes a single row of canisters down the center of the room, and a pillar width of 25 feet. Two rows of canisters, each 4-foot distance from 30-foot-wide pillars, are assumed for the 30-foot-wide room. The 50-foot-wide room also assumes two rows of canisters, each located 4-foot distance from 50-footwide pillars. Figure 3-31 shows that, at large pitches where the waste temperature is a constraint, this study predicts canister heat loads

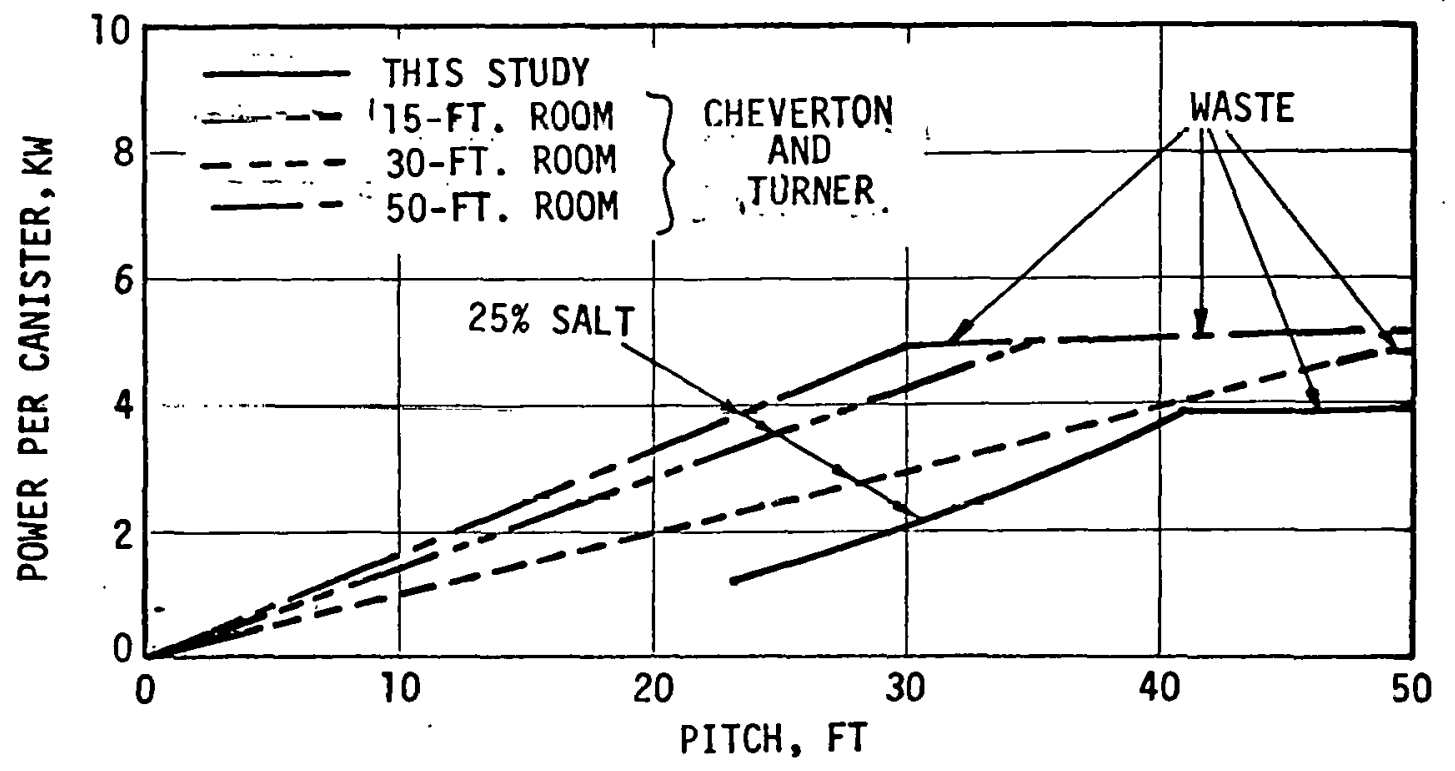

FIGURE 3-31. COMPARISON OF RESULTS FOR CALCINE-FILLED CANISTERS IN A SALT REPOSITORY (10-YEAROLD PWR WASTE 
which agree to within 75 percent. However, at small values of pitch, there is considerable difference in the results, wherein this study predicts canister powers only 40 percent of Reference 5 values. This difference can be attributed to the presence of the pillars, which provide conduction paths from the unit cell to the overburden.

Comparing these results as a function of pitch may not be altogether valid because, for a given pitch, the unit cell areas are different for the two studies. Reference 5 utilizes a rectangular unit cell with one dimension fixed and the other equal to the pitch. Therefore, the results should be compared on the basis of total area (including the pillar, where applicable) per kilowatt of waste. These results are compared in Table 3-3.

Comparison of the results in the region where the salt criteria are the dominant constraints eliminates the differences in calcine conductivity and maximum a?!outah? e temperatura. It is sean from Tab? a 3-3 that for those values of pitch where the salt temperature criteria are the dominant constraints, the heat loadings predicted in this study are approximately 85 percent of the heat loadings predicted in Reference 5 for 30-foot and 50-foot rooms, wherein the pillars occupy 50 percent of the total area. Differences in the results are much greater for the 15-foot room, in which the pillar occupies 62.5 percent of the total area. This comparison underscores the importance of the pillars in conducting heat away from the unit cell. 
TABLE 3-1. COMPARISON OF AREAL POWER DENSITIES

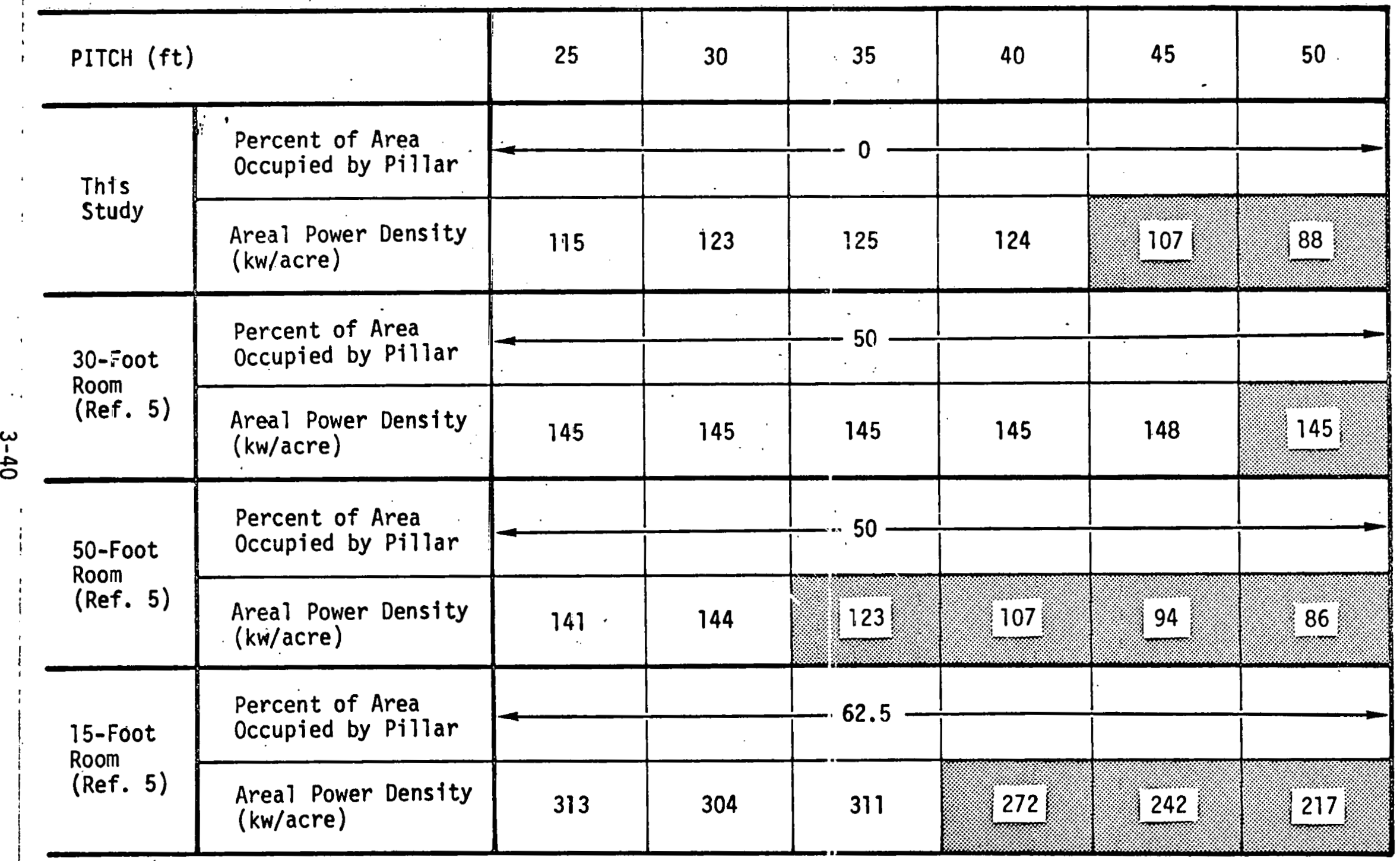

Areal Power Density Constrained by Salt Temperature Critel"ia

Area 1 Power Density Constrained by Waste Temperature Critision 


\section{CONCLUSIONS AND RECOMMENDATIONS}

The canister design constraints (i.e., the maximum allowable inside diameters and corresponding heat loadings) are summarized in Tables 4-1 and 4-2 for waste which is derived from reprocessing PWR fuel and is incorporated in borosilicate glass-filled canisters and calcine-filled canisters. For interim storage, these design constraints are presented parametrically in terms of: the time since reprocessing (i.e., the waste age) at which the canister enters interim storage; the type of cooling used during interim storage (i.e., recirculated-water cooling or passive air cooling); the, temperature constraints imposed (i.e., waste temperature only, or waste temperature plus canister temperature); and whether or not the canister is overpacked. For geologic storage is is assumed that the canister is always overpacked, enters geologic storage 10 years after reprocessing and is emplaced in eithar $\equiv$ salt. shele or hasalt renncitory.

The design constraints shown for borosilicate glass-filled canisters reflect a typical fin design: in this case, 8 fins, each 0.25 -inch-thick, which extend radially from a point 1.5 inches from the canister centerline to a point 0.5 inch from the canister. Other fin designs would result in different design constraints. Although the thermal model 'homogenized' the fin/waste combination, it was found to typically provide results accurate to within one percent of the results from a more detailed model.

As seen in Tables 4-1 and 4-2, short-aged wastes in some cases require canisters of very small diameter. If other considerations (e.g., costs) dictate a fixed canister diameter, then the high-level liquid waste must be aged for a minimum period prior to reprocessing. The data presented in Section 3 shows the minimum waste age required as a function of canister di ameter.

Water-cooled interim storage allows significantly greater canister diameters and heat loadings than passive storage in air. In the unlikely event of an-accident during water-cooled interim storage which results in loss of water, the results may not be catastrophic: in a typical case investigated, the results showed only that the canister temperature would equilibrate within the $304 \mathrm{~L}$ stainless steel sensitization regime. If water- 
TABLE 4-1. DESIGN CONSTRAINTS FOR CANISTERS WITH PWR WASTE. IN BOROSILICATE GLASS (1)

\begin{tabular}{|c|c|c|c|c|c|c|c|c|c|c|c|c|c|c|}
\hline \multirow{4}{*}{$\begin{array}{l}\text { WASTE } \\
\text { AGE } \\
\text { (YRS) }\end{array}$} & \multicolumn{8}{|c|}{ INTERIM STORAGE } & \multicolumn{6}{|c|}{ GEOLOGIC STORAGE ${ }^{(4)}$} \\
\hline & \multicolumn{4}{|c|}{$T_{\text {WASTE }} \leq 800^{\circ} \mathrm{C}$} & \multicolumn{4}{|c|}{$\begin{array}{l}T_{\text {WASTE }} \leq 800^{\circ} \mathrm{C} \\
T_{\text {CANISTER }} \leq 350^{\circ} \mathrm{C}\end{array}$} & \multicolumn{3}{|c|}{$T_{\text {WASTE }} \leq 800^{\circ} \mathrm{C}$} & \multicolumn{3}{|c|}{$\begin{array}{l}T_{\text {WASTE }} \leq 800^{\circ} \mathrm{C} \\
T_{\text {CANISTER }} \leq 350^{\circ} \mathrm{C}\end{array}$} \\
\hline & \multicolumn{2}{|c|}{ WATER } & \multicolumn{2}{|c|}{ AIR } & \multicolumn{2}{|c|}{ WATER } & \multicolumn{2}{|c|}{ AIR } & \multirow{2}{*}{ SALT } & \multirow{2}{*}{ SHALE } & \multirow{2}{*}{ BASALT } & \multirow{2}{*}{ SALT } & \multirow{2}{*}{ SHALE } & \multirow{2}{*}{ BASALT } \\
\hline & W/ $O P^{2}$ & $W / O O P^{3}$ & $W / O P$ & W/O OP & $W / O P$ & $W / 0 \quad O P$ & W/ OP & $W / O P$ & & & & & & \\
\hline 0 & $\begin{array}{c}7.2 \\
(19.2)\end{array}$ & $\begin{array}{c}11.0 \\
(45.7)\end{array}$ & $\begin{array}{l}5.0 \\
(9.3)\end{array}$ & $\begin{array}{c}8.0 \\
(23.8)\end{array}$ & $\begin{array}{l}4.5 \\
(7.6)\end{array}$ & $\begin{array}{c}11.0 \\
(45.7)\end{array}$ & $\begin{array}{l}2.3 \\
(2.6)\end{array}$ & $\begin{array}{l}4.0 \\
(6.1)\end{array}$ & & & & & & \\
\hline 1 & $\begin{array}{l}13.0 \\
(25.0)\end{array}$ & $\begin{array}{c}17.0 \\
(43.3)\end{array}$ & $\begin{array}{l}11.0 \\
(17.7)\end{array}$ & $\begin{array}{c}14.0 \\
(29.0)\end{array}$ & $\begin{array}{l}10.5 \\
(16.1)\end{array}$ & $\begin{array}{c}17.0 \\
(43.3)\end{array}$ & $\begin{array}{c}5.2 \\
(3.9)\end{array}$ & $\begin{aligned} c .0 \\
(11.7)\end{aligned}$ & & & & & & \\
\hline 3 & $\begin{array}{l}21.0 \\
(25.3)\end{array}$ & $\begin{array}{c}25.5 \\
(37.7)\end{array}$ & $\begin{array}{c}19.5 \\
(27.8)\end{array}$ & $\begin{array}{l}21.0 \\
(25.3)\end{array}$ & $\begin{array}{l}21.0 \\
(25.3)\end{array}$ & $\begin{array}{l}25.5 \\
(37.7)\end{array}$ & $\begin{array}{l}12.0 \\
(8.0)\end{array}$ & $\begin{array}{l}27.0 \\
(25.3)\end{array}$ & & & & & & \\
\hline 5 & $\begin{array}{c}27.0 \\
(24.6)\end{array}$ & $\begin{array}{c}32.0 \\
(34.8)\end{array}$ & $\begin{array}{c}25.0 \\
(21.0)\end{array}$ & $\begin{array}{c}27.0 \\
(24.6)\end{array}$ & $\begin{array}{l}27.0 \\
(24.6)\end{array}$ & $\begin{array}{c}32.0 \\
(34.8)\end{array}$ & $\begin{array}{l}20.0 \\
(13.3)\end{array}$ & $\begin{array}{c}27.0 \\
(2.4 .6)\end{array}$ & & & & & & \\
\hline 10 & & & & & & & & & $\begin{array}{l}\sim 22.0 \\
(9.5)\end{array}$ & $\begin{array}{l}15.0 \\
(4.3)\end{array}$ & $\begin{array}{l}19.0 \\
(7.1)\end{array}$ & $\begin{array}{r}n 17.0 \\
(5.6)\end{array}$ & $\begin{array}{l}10.5 \\
(2.1)\end{array}$ & $\begin{array}{l}10.5 \\
(2.1)\end{array}$ \\
\hline
\end{tabular}

(1) Numbers shown in the table are the maximum allowable canister inside diameters, in inches. Numbers in parentheses are the corresponding heat loadings in kllowatts.

(2) With overpack.

(3) Without overpack

(4) All canisters in geologic storage are overpacked 
TABLE 4-2. DESIGN CONSTRAINTS FOR CANISTERS WITH PWR WASTE IN CALCINE(1)

\begin{tabular}{|c|c|c|c|c|c|c|c|c|c|c|c|c|c|c|}
\hline \multirow{4}{*}{$\begin{array}{l}\text { WASTE } \\
\text { AGE } \\
\text { (YRS) }\end{array}$} & \multicolumn{8}{|c|}{ INTERIM STORAGE } & \multicolumn{6}{|c|}{ GEOLOGIC STORAGE $^{(4)}$} \\
\hline & \multicolumn{4}{|c|}{$T_{\text {WASTE }} \leq 700^{\circ} \mathrm{C}$} & \multicolumn{4}{|c|}{$\begin{array}{l}T_{\text {WASTE }} \leq 700^{\circ} \mathrm{C} \\
T_{\text {CANISTER }} \leq 350^{\circ} \mathrm{C}\end{array}$} & \multicolumn{3}{|c|}{$T_{\text {WASTE }} \leq 700^{\circ} \mathrm{C}$} & \multicolumn{3}{|c|}{$\begin{array}{l}T_{\text {WASTE }} \leq 700^{\circ} \mathrm{C} \\
T_{\text {CANISTER }} \leq 350^{\circ} \mathrm{C}\end{array}$} \\
\hline & \multicolumn{2}{|c|}{ WATER } & \multicolumn{2}{|c|}{ AIR } & \multicolumn{2}{|c|}{ WATER } & \multicolumn{2}{|c|}{ AIR } & \multirow{2}{*}{ SALT } & \multirow{2}{*}{ SHALE } & \multirow{2}{*}{ BASALT } & \multirow{2}{*}{ SALT } & \multirow{2}{*}{ SHALE } & \multirow{2}{*}{ BASALT } \\
\hline & $W / O P^{2}$ & W/O OF 3 & W/ OP & $W / O O P$ & W/ OP & $W / O O P$ & $W / O P$ & W/O OP & & & & & & \\
\hline 0 & \begin{tabular}{|l|}
2.5 \\
$(4.2)$
\end{tabular} & $\begin{array}{c}3.0 \\
(6.1)\end{array}$ & $\begin{array}{l}2.1 \\
(3.0)\end{array}$ & $\begin{array}{c}2.4 \\
(3.9)\end{array}$ & $\begin{array}{l}2.5 \\
(4.2)\end{array}$ & $\begin{array}{c}3.0 \\
(6.1)\end{array}$ & $(1.6)$ & $\begin{array}{c}2.4 \\
(3.9)\end{array}$ & & & & & & \\
\hline 1 & $\begin{array}{c}3.8 \\
(3.8)\end{array}$ & $\begin{array}{c}4.7 \\
(5.7)\end{array}$ & $\begin{array}{l}3.5 \\
(3.2)\end{array}$ & $\begin{array}{l}3.8 \\
(3.8)\end{array}$ & $\begin{array}{c}3.8 \\
(3.8)\end{array}$ & $\begin{array}{l}4.7 \\
(5.7)\end{array}$ & $\begin{array}{c}3.3 \\
(2.8)\end{array}$ & $\begin{array}{c}3.8 \\
(3.8)\end{array}$ & & & & & & \\
\hline 3 & $\begin{array}{c}6.6 \\
(4.3)\end{array}$ & $\begin{array}{l}7.7 \\
(5.9)\end{array}$ & $\begin{array}{l}6.2 \\
(3.8)\end{array}$ & $\begin{array}{l}6.5 \\
(4.2)\end{array}$ & $\begin{array}{l}6.6 \\
(4.3)\end{array}$ & $\begin{array}{l}7.7 \\
(5.7)\end{array}$ & $\begin{array}{l}6.2 \\
(3.8)\end{array}$ & $\begin{array}{l}6.5 \\
(4.2)\end{array}$ & & & & & & \\
\hline 5 & $\begin{array}{c}9.0 \\
(4.7)\end{array}$ & $\begin{array}{l}10.0 \\
(5.7)\end{array}$ & $\begin{array}{l}8.3 \\
(4.0)\end{array}$ & $\begin{array}{l}8.8 \\
(4.5)\end{array}$ & $\begin{array}{l}9.0 \\
(4.7)\end{array}$ & $\begin{array}{l}10.0 \\
(5.7)\end{array}$ & $\begin{array}{c}8.3 \\
(4.0)\end{array}$ & $\begin{array}{c}8.8 \\
(4.5)\end{array}$ & & & & & & \\
\hline 10 & & & & & & & & & $\begin{array}{l}11.0 \\
(4.1)\end{array}$ & $\begin{array}{l}8.5 \\
(2.4)\end{array}$ & $\begin{array}{l}9.0 \\
(2.7)\end{array}$ & $\begin{array}{l}11.0 \\
(4.1)\end{array}$ & $\begin{array}{l}7.5 \\
(1.9)\end{array}$ & $\begin{array}{l}7.5 \\
(1.9)\end{array}$ \\
\hline
\end{tabular}

(1) Numbers'shown in the table are the maximum allowable canister inside diameters, in inches. Numbers in parentheses are the corresponding heat loadings, in kilowatts.

(2) With overpack

(3) Without overpack

(4) All canisters in geologic storage are overpacked. 
cooling is selected as the technique for interim storage the results of a loss-of-coolant accident should be investigated in greater detail.

If the facilities available for water-cooled storage are limited compared to the facilities available for passive, air-cooled storage, the canister can be emplaced in water-cooled storage for a period and then removed and placed in air-cooled storage. The data presented in Section 3 can be used to determine the required initial durations of water-cooled storage.

The inclusion of an overpack around the canister always results in smaller allowable canister diameters due to the thermal resistance imposed by the air which is assumed to be in the gap between the overpack and the canister. Some advantage can be gained during interim storage by filling this gap with helium instead of air, due to the relatively high condicti of helium. Likewise, helium would provide an advantage during geologic storage if it can be shown that the overpack remains leak-tight for a period in excess of that required for the waste temperature or canister temperature to reach a maximum.

The temperature of the surrounding ambient air during air-cooled storage has little effect on the design constraints. However, the emissivity of the exposed surface, whether it is the overpack or the canister, has a major effect on the design constraints. The emissivity used in this study is in the range of approximately 0.7 to 0.85 .

Because of time and resource constraints, the thermal model of the canister/repository configuration used in this study was a two-dimensional, $R-Z$ representation. The model necessarily excluded nearby walls, or pillars, which can be effective in conducting heat upward to the overburden. A comparison of the results obtained here with the earlfer results of a three-dimensional analysis indicates that the three-dimensional model results in somewhat larger allowable canister diameter and heat loading at any given pitch, and a higher maximum heat loading per gross (room plus pillar) acre. The differences appear to be on the order of 10 to 20 percent, and are probably due to the increased thermal conductance afforded by the pillars. Therefore, depending on the room and pillar dimensions, the results of this study may be conservative. 
In geologic storage, the maximum allowable canister diameter increases with increasing pitch until a pitch is reached beyond which there is no further thermal interaction between canisters. Beyond this value of pitch, the canister diameter remains a constant which is defined by the waste characteristics and the thermal diffusivity of the repository medium. The geologic storage design constraints shown in Tables 4-1 and 4-2 are thus the largest possible diameters and heat loadings which can be accommodated in the various repository media.

It is seen in Tables 4-1 and 4-2 that a salt repositary allows the largest single canister diameter while shale allows the smallest diameter. Additionally, the results for a salt repository show that the maximum allowable heat loading per gross acre is essentially independent of canister diameter. This is due to the one percent and 25 percent salt volume-temperature criteria. Thus, the canister diameter ultimately seieted may bo the maximum size utich can be acrommodated by the repository surface storage facilities, the transporter, etc. On the, other hand, the results for shale and basalt indicate that the maximum allowable heat loading per acre increases with decreasing canister diameter. This result is due to the assumption that there are no temperature constraints for shale and basalt; thus, the only constraint is on the waste centerline temperature. The net effect of maximizing the areal heat loading, and emplacing many, small-diameter canisters in shale and basalt is to raise the bulk average temperature of the mine. The results show that a significantly greater heat loading per gross acre is allowable in shale or basalt than in salt.

Limiting the temperature of the canister to $350^{\circ} \mathrm{C}$, to avoid sensitization when overpacked in geologic storage, is seen to impose a major penalty on glass-filled canisters, and a lesser penalty on calcine-filled canisters. These results are due to the excellent thermal conductivity of the glass/fin combination, which normally causes a canister temperature which is not far below the glass centerline temperature of $800^{\circ} \mathrm{C}$. Alternately, the temperature of a calcine-filled canister is normally much lower than the centerline temperature, due to the large thermal resistance imposed by the calcine. Thus, the beneficial effect of the fins in conducting heat away from the centerline is largely negated if the canister must be maintained at $350^{\circ} \mathrm{C}$ or below. 
The baseline cases examined in this study assumed that the annulus around the overpack, and the mine room, are both backfilled with crusheid mine material after the canister has been emplaced. Deletion of the room backfill causes a slight reduction in allowable diameter. Deletion of the annulus backfill has an effect which is dependent on the geologic medium. Because crushed salt in the annulus is likely to become fully compacted in a short time after emplacement, and because the conductivity of compacted salt is relatively high, deletion of the crushed salt annulus, allowing only air in this gap, would reduce the allowable canister diameter. However, in shale and basalt, deletion of the crushed material in the annulus can improve heat transfer across the air gap, and allow slightly larger diameters, due to the ponr conductivity of the crushed material.

Because of the relatively poor thermal conductivity of the calcine waste form, the allowable canister diameters and heat loadings for calcine aire seeni to te significant?j smal!er than for borosilicate glass. This disadvantage can be overcome, with minimum apparent impact to cost and operations, by including metaliic fins or constructing the canister as an annulus.

The ability to define an acceptable canister geometry, or geometries, is directly affected by the degree to which materials' properties and waste management operations have been defined. Therefore, canister design definition is likely to be an evolutionary process, in keeping with the evolving NWTS program and the state of knowledge regarding materials' properties and their limitations. This study, conducted at a relatively early stage in the development of a national high-level waste management program, has resulted in a preliminary definition of the impact of heat transfer considerations on canister sizing for a range of waste form and geologic repository candidates. These results must be integrated with the results of other, parallel studies on the effects of codes and standards, etc., before an overall, initial canister sizing can be made. As the NWTS program matures, it is likeiy that the number of candidate waste forms and repository media will be reduced, and/or specific geologic sites will be selected for dctailed investigation. More intensive heat transfer studies can then be conducted. It is recommended that the following areas be investigated in any subsequent studies: 
- Thi r.a is suggest that, considering repository costs, there is a cuspoptimized canister size for each of the three candidate geologic media. The results also suggest that the gross mine area required decreases if the mine is configured with smali rooms and large pillars. Therefore, a comprehensive systems analysis, encompassing the complete life-cycle of the canister, should be conducted to determine these cost-optimum sizes and the sensitivity of cost to variables such as canister size. The potential advantages of materials other than 304L stainless should also be explored and the costs of such materials should be traded off in this systems study.

- Actual thermophysical data from samples taken at candidate repository sites should be included wherever possible.

- The thermal limitations of shale and basalt should be defined, and the one percent and 25 percent sait volume-temperature criteria should be verified for a specific repository site of interest.

- Further definition should be made of the time period required for : and nperations associated with, the period of retrievabilit:? Specificaliy, the need for, and duration of, air circulation should be defined.

- Assuming that applicable codes and standards will require the $304 \mathrm{~L}$ stainless canister to be overpacked, it should be determined whether it is also necessary to maintain the canister at $350^{\circ} \mathrm{C}$ or less after emplacement, especially in shale or basalt where corrosion may not be as significant as in salt.

- If the $350^{\circ} \mathrm{C}$ canister temperature constraint is deleted then alternate, more effective fin configurations should be investigated.

- If calcine continues to be a candidate waste form, internal metallic fins should be included in the baseline canister design. This feature will have the greatest impact on calcine canisters destined for a salt repository.

- Verify the maximum allowable temperature of each candidate waste form. For example, devitrification of the borosilicate glass, if it occurs, takes place only at the location of peak temperature (i.e., the canister center). Because the outer layer of glass will be unaffected, some degree of centerline devitri- fication may be acceptable, thus allowing higher centerline temperatures and larger canisters.

If metallic fins continue to be included for borosilicate glassfilled canisters, or if they are adopted for calcine-filled canisters, long-term fin integrity, and contact resistance, in the hottest portions of the canisters should be verified. 


\section{-5.0 REFERENCES}

1. "National Waste Terminal Storage Program Progress Report For Period April 1, 1975 to September 30, 1976", Y/OWI-8, Office of Waste Isolation, Oak Ridge, Tennessee, November 30, 1976.

2. Discussion with E. L. Moore, Rockwell Hanford Co. .

3. Discussion with S. C. Slate, Battelle Pacific Northwest Laboratories.

4. "Alternatives for Managing Wastes from Reactors and Post-Fission Operations in the LWR Fuel Cycle, Vol. 3: Alternatives for Interim Storage and Transportation", ERDA-76-43, Vol. 3, May 1976.

5. R. C. Cheverton and W. D. Turner, "Thermal Analysis of the Radioactive Waste Repository, Progress Through March 1972," ORNL-4789, Oak Ridge National Laboratory, Septembier 1972.

6. R. D. Cheverton and W. D. Turner, "Thermal Analys is of the Radioactive Waste Repository, Progress Through June 1971", ORNL-4726, Oak Ridge Nationa! Laboratory, December 1971.

7. Discussion with Glen Jenks, Office of Waste Isolation.

8. "The Selection and Evaluation of Thermal Criteria for a Geologic Waste Isolation Facility in Salt", Y/OWI/SUB-76/07220, Science Applications, Inc., September 1976.

9. Francis Birch and Harry Clark, "The Thermal Conductivity of Rocks and Its Dependence Upon Temperature and Composition", Am.Jour.Sc:, Vol. 238, No. 8, August 1940.

10. R. L. Bradshaw, W. C. McClain, eds., "Project Salt Vault: A Demonstration of the Disposal of High-Activity Solidified Wastes in Underground Salt Mines", ORNL-4555 UC-70, Oak Ridge National Laboratory, Oak Ridge, Tennessee, April 1971.

11. Handbook of Physical Constants, Rev. Ed., Geo. Soc. of America, Memoir 97, 1966.

12. Thermophystcal Properlies of Matter, Thermophysical Properties Research Center, Published by IFI/Plenum Data Corp.

13. W. H. Somerton and G. D. Boozer, Thermal Characteristics of Porous Rocks at Elevated Temperatures, Petroleum Transactions, Vol. 219, 1960:

14. J. R. Berreth, et al, "Stabilization and Storage of Solidified High-Level Radioactive Wastes", Nuclear Technology, January 1977. 


\section{REFERENCES (Continued)}

15. M. J. Steindler, N. M. Levita, W. J. Mecham, W. B. Seefeldt, L. E. Trevorrow, T. J. Gerding, B. J. Kullen, D. S. Webster, L. Burris, "Chemical Engineering Division Waste Management Programs Quarterly Report Apri1-June 1974", ANL-8134, Argonne National Laboratory, Argonne, Illinois, November 1974.

16. G. M. Jaffe, "Development of a Backward Differencing Technique for Thermal Analyses to be Used by SINDA", TRW Interoffice Correspondence 77.6821.5.3-3, 20 June 1977.

17. J. L. McElroy, "Quarterly Progress Report, Research and Development Activities Waste Fixation Program July Through September 1975", BNWL-1949,-Battelle Pacific Northwest Laboratories, Richland, Washington, January 1976. 
APPENDIX A. THERMAL PROPERTIES

A. 1 HIGH-LEVEL WASTE FROM LWR-U FUEL

Heat Generation Rate (Reference A-1)

Time Since

Reprocessing (yrs)

1

2

3

4

5

6

?

8

9

10

15

20

25

30

35

40

50

60

$70^{\circ}$

80

90

100
Heat Rate (watts/MTU) PWR Waste ${ }^{(a)(c)}$ BWR Waste ${ }^{(b)(c)}$

5731

3367.4

2242.4

1657.9

1335.6

1143.8

1013.2

Sล̂̃.7

- 862.2

812.8

665.5

576.3

505.9

446.3

394.3

349.8

274.9

217.2

173.3

137.9

110.4

88.8

(a) Enriched to 3.24 percent U; 33,000 MWD/MT burnup.

(b) Enriched to 2.6 percent U; 27,500 MWD/MT burnup.

(c) 99.5 percent of uranium and plutonium removed during reprocessing; 0.1 percent of iodine and bromine remaining; no xenon, krypton or cladding materials; fuel is reprocessed 160 days after its discharge from the reactor. 


\section{A.1.1 Borosilicate Glass}

Bulk Density (Ref. A-2): $3.5 \mathrm{~g} / \mathrm{cm}^{3}$

$$
2.18 .3 \mathrm{ib} / \mathrm{ft}^{3}
$$

Specific Volume (Ref. A-3): $601 / \mathrm{MTU}$

$$
2.12 \mathrm{ft}^{3} / \mathrm{MTU}
$$

Maximum Allowable Temp. (Ref. A-3): $800^{\circ} \mathrm{C}$

$$
1472^{\circ} \mathrm{F}
$$

Thermal Conductivity (Ref. A-3):

$$
\begin{aligned}
& K=8.237 \times 10^{-3}+7.9 \times 10^{-7} \mathrm{~T}\left(\text { watts } / \mathrm{cm}^{\circ} \mathrm{K}\right) \\
& K=0.486+2.537 \times 10^{-5} \mathrm{~T}\left(\frac{\mathrm{Btul}}{\mathrm{hrft}}\right)
\end{aligned}
$$

Figure A-1 summarizes the borosilicate glass conductivities from various references. Wute that the values used in this study f from ?e?. a A-3) are somewhat lower than have been used previousiy.

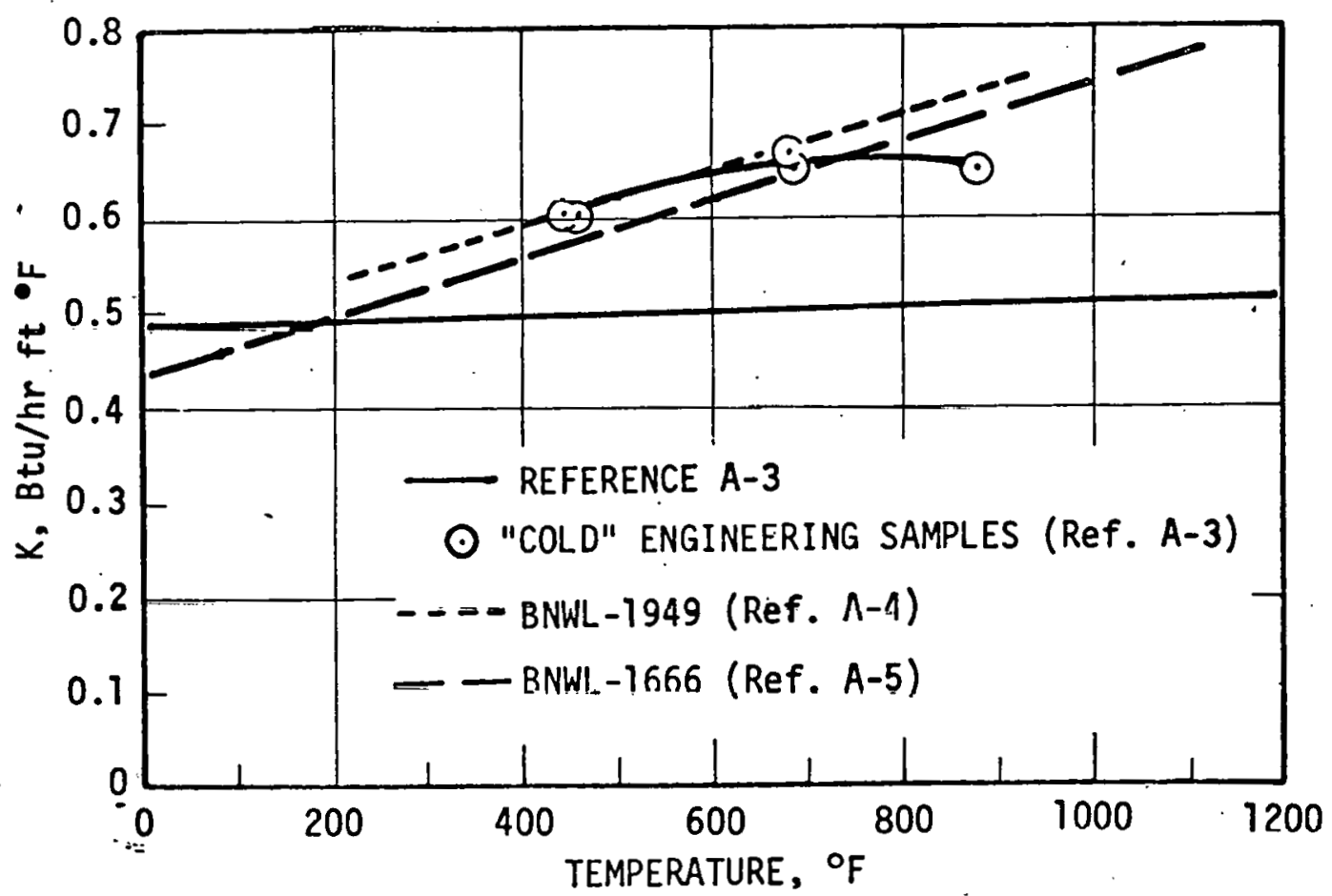

FIGURE A-1. BOROSILICATE GLASS CONDUCTIVITY 
Specific Heat (Ref. A-3):

$$
\begin{aligned}
& \rho C_{p}=1.74+0.00105 \mathrm{~T} \text { (watts } \mathrm{sec} / \mathrm{cm}^{3}{ }^{\circ} \mathrm{K} \text { ) } \\
& \text { Thus, for a density, } \rho \text {, of } 3.5 \mathrm{~g} / \mathrm{cm}^{3} \\
& \begin{aligned}
C_{p} & \left.=0.497+3.000 \times 10^{-4} \mathrm{~T} \text { (watts sec } / \mathrm{g}^{\circ} \mathrm{K}\right) \\
& =0.119+0.398 \times 10^{-4} \mathrm{~T}\left(\text { Btu } / 1 \mathrm{~b}^{\circ} \mathrm{F}\right) .
\end{aligned}
\end{aligned}
$$

\section{A.1.2 Calcine}

Bulk Density (Ref. A-6): $2.2 \mathrm{~g} / \mathrm{cm}^{3}$

$$
137.2 \mathrm{lb} / \mathrm{ft}^{3}
$$

Specific Volume (Ref. A-6): $36.8 \cdot \mathrm{l} / \mathrm{MTU}$

$$
1.30 \mathrm{ft}^{3} / \mathrm{MTU}
$$

Maximum Al lowable Temp. (Pef. A-6): $700^{\circ} \mathrm{C}$

Thermal Conductivity (Ref. A-7):

$$
\begin{aligned}
& K=\left[0.177+10^{-4}(\rho-2100)\right][1+0.00148 \mathrm{~T}]\left(\frac{\text { watts }}{\mathrm{m}^{\circ} \mathrm{K}}\right) \\
& \text { where: } T \\
& T \sim{ }^{\circ} \mathrm{C} \\
& \rho \sim \text { density, } \mathrm{kg} / \mathrm{m}^{3} \\
& K=[0.102+\left.10^{-4}(9.255 \rho-121)\right]\left[0.974+8.23 \times 10^{-4} \mathrm{~T}\right]\left(\frac{\mathrm{Btu}}{\mathrm{hrft} \cdot}\right) \\
& \text { where: } T \sim{ }^{\circ} \mathrm{F} \\
& \rho \sim 1 \mathrm{~b} / \mathrm{ft}^{3}
\end{aligned}
$$

Specific Heat (Ref. A-7): 650 Joules $/ \mathrm{kg}^{\circ} \mathrm{K}$

$$
0.155\left(\frac{\mathrm{Btu}}{\mathrm{Ib}^{\circ} \mathrm{F}}\right)
$$

\section{A.2 DISPOSAL MEDIA}

The ambient temperature in each of the three disposal media (i.e., sait, shale and basalt) due to geothermal heat flux is shown in Figure $A-2$. The geothermal heat flux giving rise to this temperature gradient was calcuiated to be:

$$
0.023 \mathrm{Btu} / \mathrm{ft}^{2} \mathrm{hr}
$$




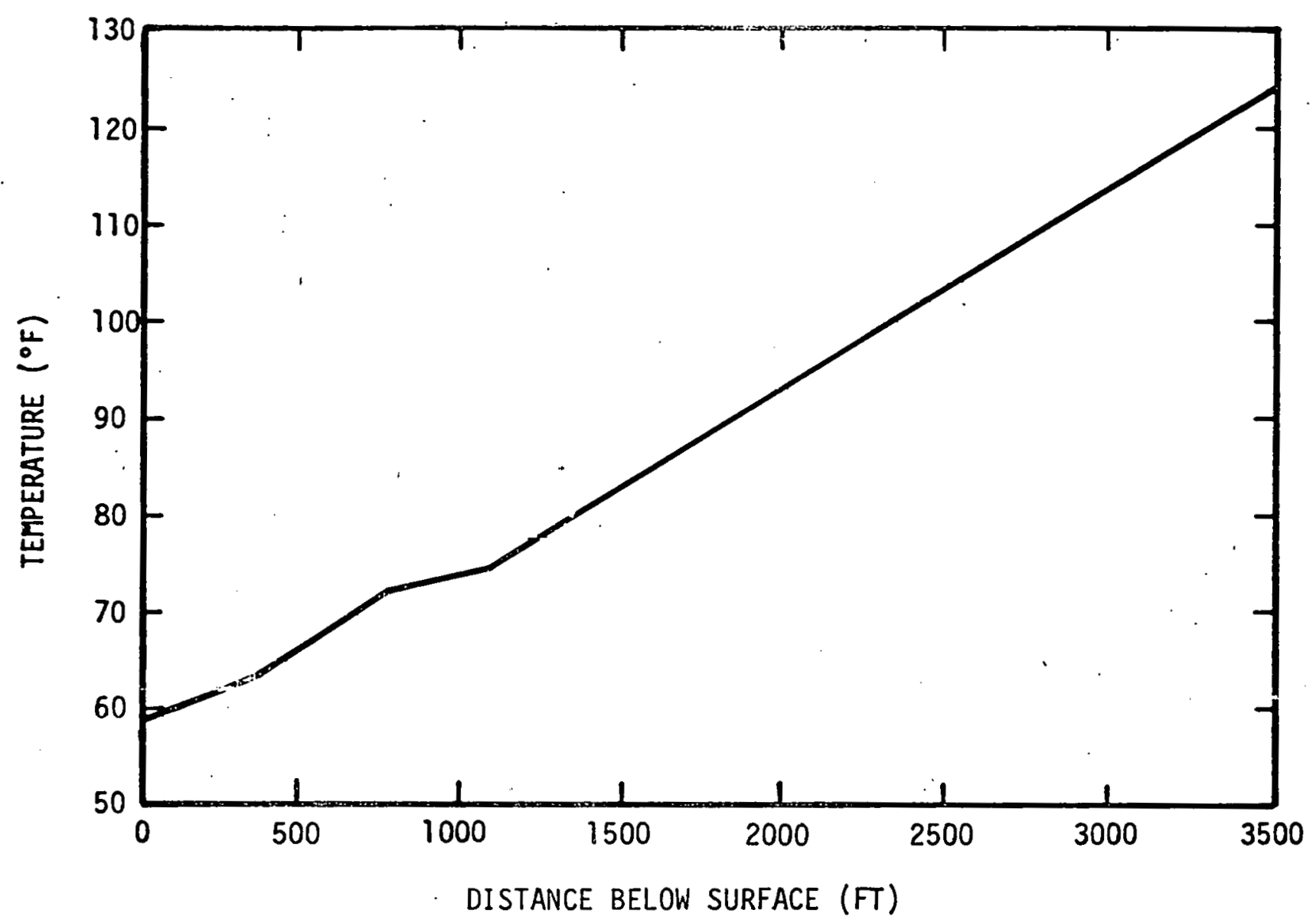

FIGURE A-2. GEOLOGIC FORMATION TEMPERATURES PRIOR TO BURIAL OF WASTE (Ref. A-8)

\section{A.2.1 Salt}

\section{A.2.1.1 Fully Compacted Salt}

Bulk Density (Ref. A-9): $2.160 \mathrm{~g} / \mathrm{cc}$

$$
134.7 \mathrm{lb} / \mathrm{ft}^{3}
$$

Maximum Allowable Temp. (Ref. A-9):

o. No more than 1 percent of the salt volume in a unit cell $\because$ (vertical height same as the waste canister) shall exceed $250^{\circ} \mathrm{C}\left(482^{\circ} \mathrm{F}\right)$.

- No more than 25 percent of the salt volume in a unit cell shall exceed $200^{\circ} \mathrm{C}\left(392^{\circ} \mathrm{F}\right)$. 
Thermal Conductivity (Ref. A-9):

Temperature

Conductivity (Btu/hr ft $\left.{ }^{\circ} \mathrm{F}\right)$

$\frac{{ }^{\circ} \mathrm{C}}{0} \quad \frac{{ }^{\circ} \mathrm{F}}{32}$

3.53

$50 \quad 122$

2.90

$100 \quad 212$

2.43

$150 \quad 302$

2.08

$200 \quad 392$

1.80

$250 \quad 482$

1.60

$300 \quad 572$

1.44

$350, \quad 662$

1.33

Thermal Diffusivity (Ref. A-10):

Temperature

Diffusivity $\left(\mathrm{ft}^{2} / \mathrm{hr}\right)$

${ }_{0}^{\circ} \mathrm{C} \quad \frac{{ }^{\circ} \mathrm{F}}{32}$

0.15

$50 \quad 122$

0.105

$100 \quad 212$

0.085

$150 \quad 302$

0.075

$200 \quad 392$

0.063

$250 \cdot 482$

0.055

$300 \quad 57 ?$

0.045

350

662

0.040

Heat Capacity (calculated from diffusivity, conductivity and density):

Temperature

Heat Capacity $\left(\mathrm{Btu} / 7 \mathrm{~b}^{\circ} \mathrm{F}\right)$

${ }^{\circ} \mathrm{C} \quad{ }^{\circ} \mathrm{F}$

$0 \quad 32$

0.207

$50 \quad 122$

0.205

$.100 \quad 212$

0.202

$150 \quad 302$

0.206

$200 \quad 392$

0.216

$250 \quad 482$

0.232

$300 \quad 572$

0.247

350

662

0.250 


\section{A.2.1.2 Crushed Salt}

Bulk Density (Ref. A-8): $98 \mathrm{lb} / \mathrm{ft}^{3}$

Maximum Allowable Temp.: Assumed to be the same as for fully compacted salt

Thermal Conductivity: Assumed to be 10 percent of values for fully compacted salt

Heat Capacity: Assumed to be the same as for fully compacted salt

Emissivity: 0.9 (assumed)

\section{A.2.2 Shale}

\section{A.2.2.1 Fully Compacted Shale}

Bulk Density (Ref. A-11): $132.51 \mathrm{~b} / \mathrm{ft}^{3}$

Maximum Allowable Temperature: Not defined

Therma I Diffusivity (Ref. A-11, direciiun not úefineud):

\begin{tabular}{cc} 
Temperature $\left({ }^{\circ} \mathrm{F}\right)$ & Diffusivity $\left(\mathrm{ft}^{2} / \mathrm{hr}\right)$ \\
\hline 200 & 0.03 \\
400 & 0.024 \\
600 & 0.019 \\
800 & 0.014 \\
900 & 0.011
\end{tabular}

Heat Capacity (Ref. A=11): .

Temperature $\left({ }^{\circ} \mathrm{F}\right) \quad$ Heat Capacity $\left(\mathrm{Btu} / \mathrm{Ib}^{\circ} \mathrm{F}\right)$

$\begin{array}{ll}200 & 0.21 \\ 400 & 0.24 \\ 600 & 0.261 \\ 800 & 0.276 \\ 900 & 0.280\end{array}$

Thermal Conductivity

Figure A-3 summarizes the data found for shale. Shale is known to be anisotropic and have a temperature-dependent conductivity. Conductivity values parallel to the bed have often been assumed to be a factor of 1.5 to 2.0 times the values perpendicular to the bed. For 


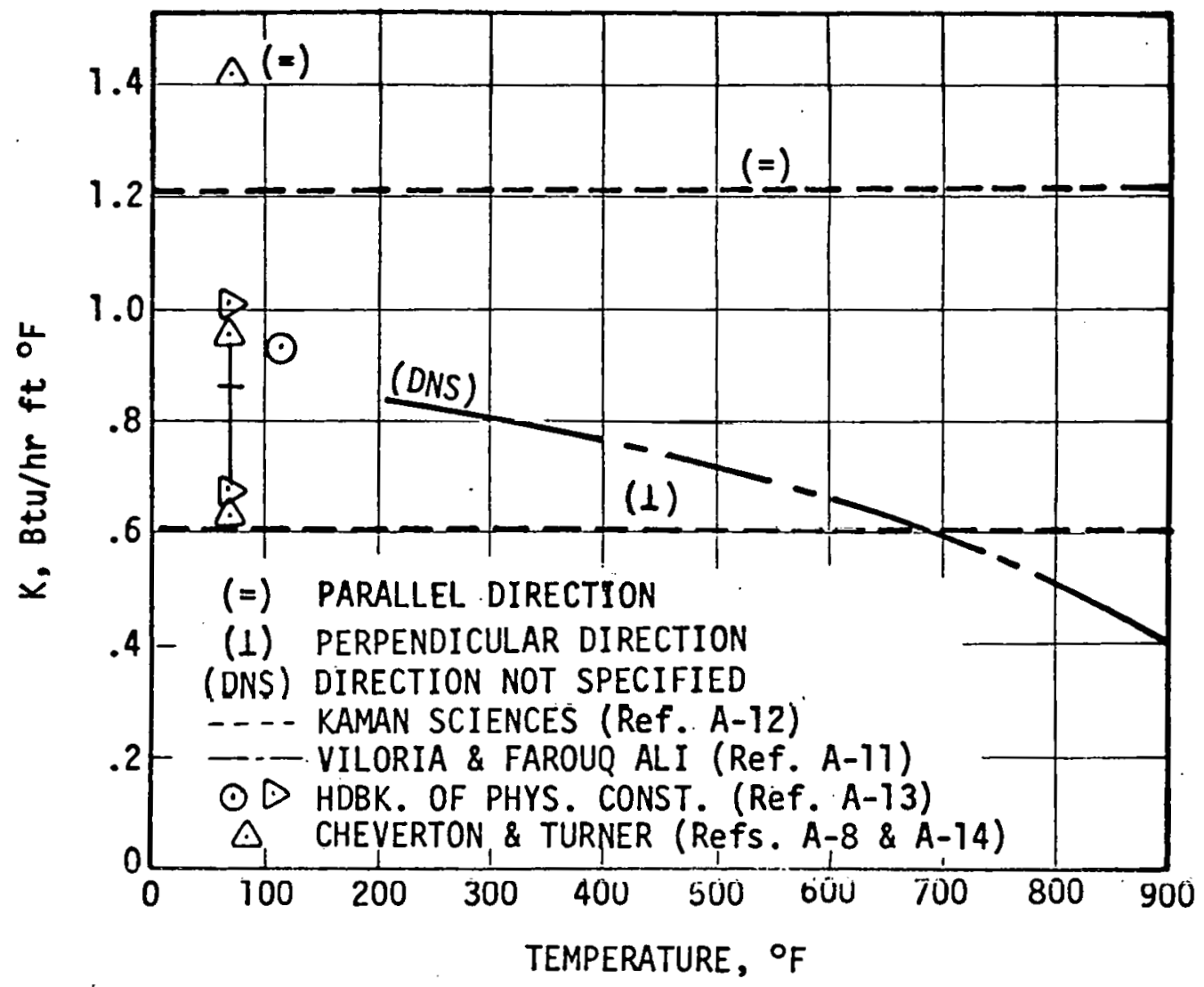

FIGURE A-3. SHALE THERMAL CONDUCTIVITY

the purposes of this study, the conductivity values calculated from the data of Viloria and Farouq Ali (Ref. A-11) were assumed to represent the perpendicular direction, and a factor of 1.5 was used to estimate the values in the parallel direction. These assumptions resulted in the following conductivity:

Temperature $\left({ }^{\circ} \mathrm{F}\right) \quad$ Conductivity $\left(\mathrm{Btu} / \mathrm{hrft}{ }^{\circ} \mathrm{F}\right)$

Perpendicular Parallel

$\begin{array}{lll}200 & 0.835 & 1.253 \\ 400 & 0.763 & 1.145 \\ 600 & 0.657 & 0.986 \\ 800 & 0.512 & 0.768 \\ 900 & 0.408 & 0.612\end{array}$

\section{A.2.2.2 Crushed Shale}

Bulk Density: $88.2 \mathrm{lb} / \mathrm{ft}^{3}$ (assumed)

Maximum Allowable Temperature: Not defined 
Heat Capacity: Assumed to be the same as for fully compacted shale. Thermal Conductivity: (Assumed to be 10 percent of average, fullycompacted shale)

Temperature $\left({ }^{\circ} \mathrm{F}\right) \quad$ Conductivity (Btu/hrft $\left.{ }^{\circ} \mathrm{F}\right)$

$\begin{array}{ll}200 & 0.104 \\ 400 & 0.095 \\ 600 & 0.082 \\ 800 & 0.064 \\ 900 & 0.051\end{array}$

Emissivity: 0.9 (assumed)

\section{A.2.3 Basalt}

\section{A.2.3.1 Fully Compacted Basalt}

Bulk Density (Ref. A-15): $2.68 \mathrm{~g} / \mathrm{cm}^{3}$

$$
i 67.2 \mathrm{ib} / \mathrm{it}^{3}
$$

Maximum Allowable Temperature: Not defined

\section{Thermal Conductivity}

Figure A-4 summarizes the values of thermal conductivity given in Ref. A-15: The scattered data at temperatures greater than approximately $600^{\circ} \mathrm{F}$ were approximated by the solid line indicated.

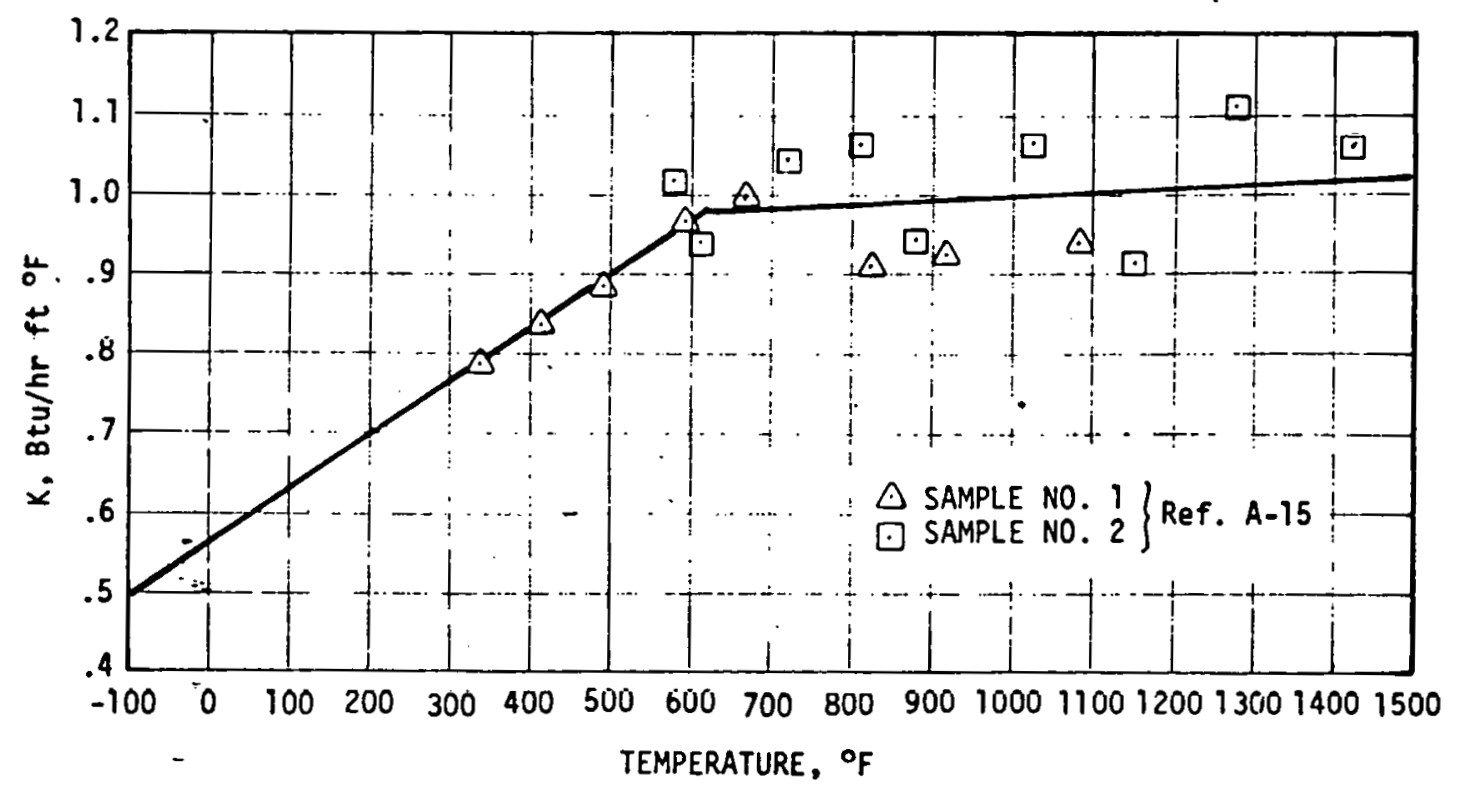

FIGURE A-4. BASALT THERMAL CONDUCTIVITY (FULLY COMPACTED) 
Specific Heat (assumed): $0.2 \mathrm{cal} / \mathrm{gm}^{\circ} \mathrm{C}$

$0.2\left(\right.$ Btu/16 $\left.{ }^{\circ} \mathrm{F}\right)$

\section{A.2.3.2 Crushed Basalt}

Bulk Density (Ref. A-15): $1.95 \mathrm{~g} / \mathrm{cm}^{3}$

$121.6 \mathrm{lb} / \mathrm{ft}^{3}$

Maximum Allowable Temperature: Not defined

Thermal Conductivity (Ref. A-15):

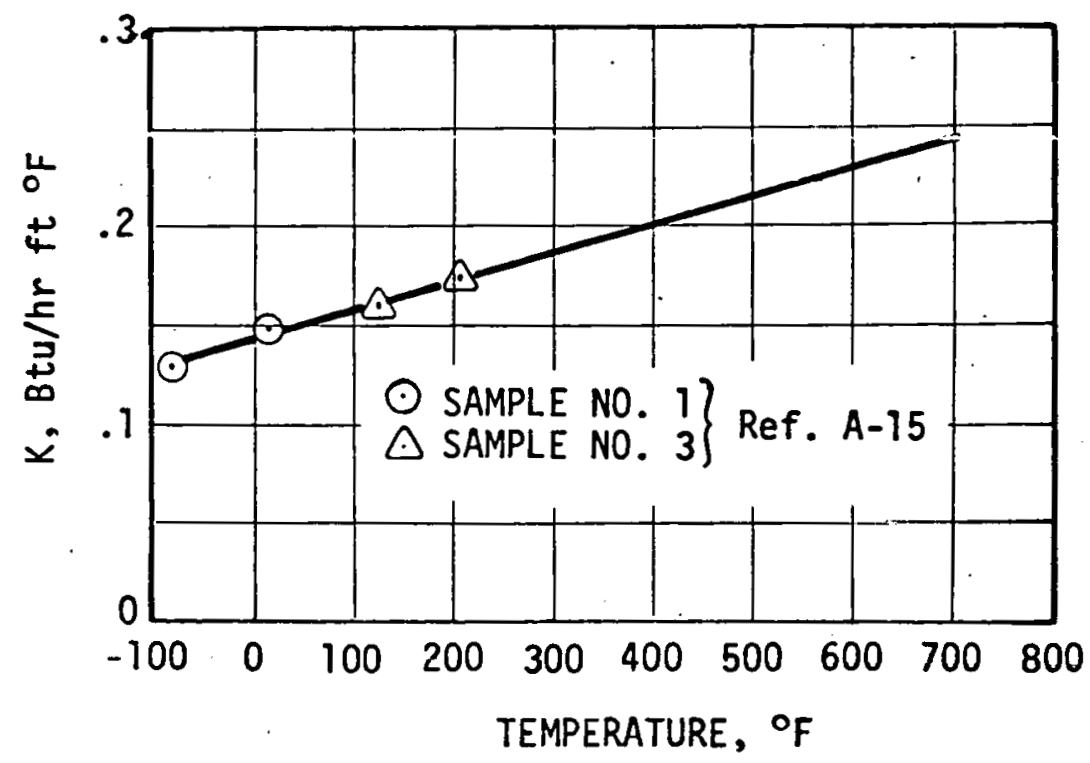

FIGURE A-5. BASALT THERMAL CONDUCTIVITY (CRUSHED)

Heat Capacity: Assumed to be the same as for fully compacted basalt. Emissivity: Assumed to be 0.9 , based on the spectral reflectance given in Reference A-16. 


\section{A. 3 WASTE PACKAGING}

\section{A.3.1 Canister (304L Stainless Steel)}

Bulk Density (Ref. A-15): $501 \mathrm{1b} / \mathrm{ft}^{3}$

Maximum Allowable Temp. (Ref. A-16): $350^{\circ} \mathrm{C}$

Thermal Conductivity (Ref. A-15):

Temperature $\left({ }^{\circ} \mathrm{F}\right)$ Conductivity $\left(\mathrm{Btu} / \mathrm{hr} / \mathrm{ft}{ }^{\circ} \mathrm{F}\right)$.

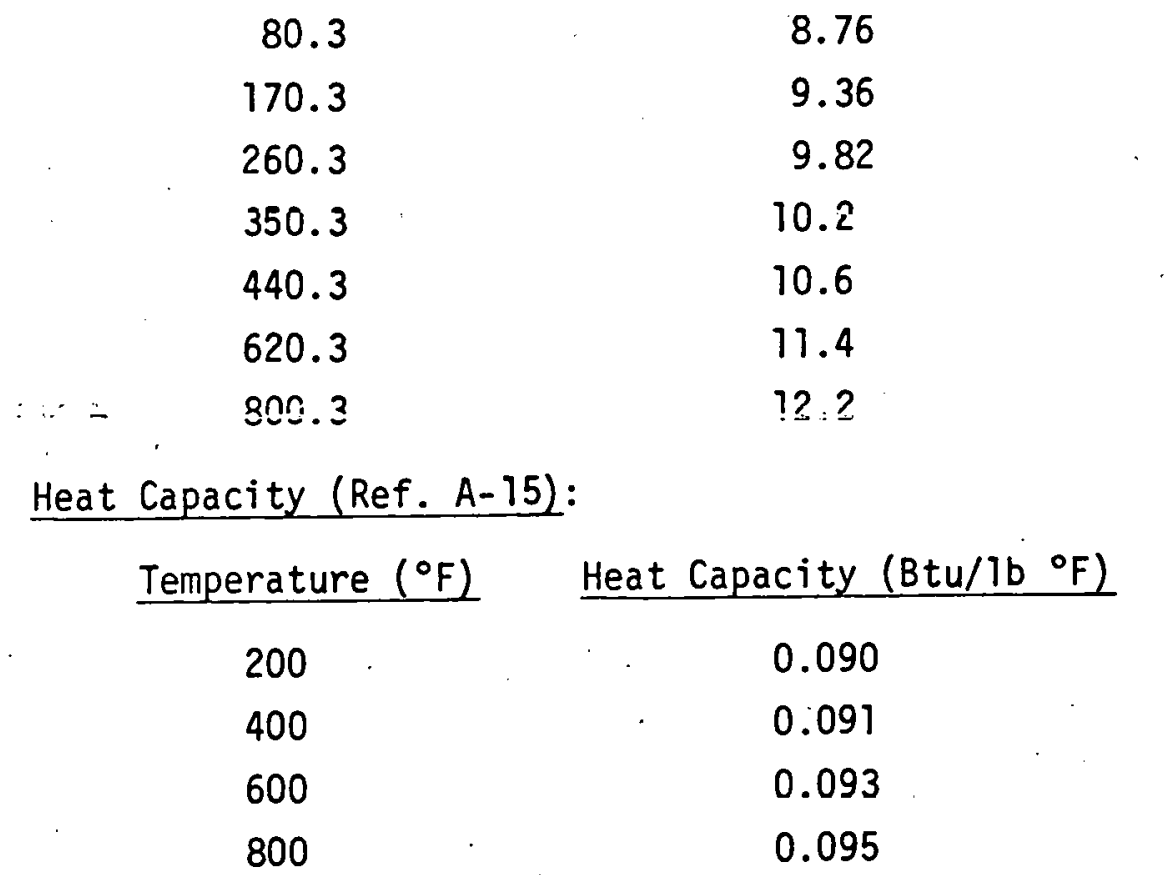

Emmisivity (Ref. A-15):

Temperature $\left({ }^{\circ} \mathrm{F}\right)$

599

900

1200

\section{Emissivity}

0.75

0.82

0.87

\section{A.3.2 Overpack and Sleeve (Carbon Steel)}

Bulk Density (Ref. A-15): 489 1b/ $\mathrm{ft}^{3}$

Maximum Allowable Temperature: Not defined 
Thermal Conductivity (Ref. A-15):

Temperature $\left({ }^{\circ} \mathrm{F}\right) \quad$ Conductivity (Btu/hrft $\left.{ }^{\circ} \mathrm{F}\right)$

$\begin{array}{rr}86.4 & 39.8 \\ 122.4 & 37.7 \\ 201.6 & 33.2 \\ 212.4 & 32.7 \\ 311.4 & 27.9 \\ 392.4 & 24.9 \\ 448.2 & 23.1 \\ 572.4 & 21.0 \\ 633.6 & 19.4 \\ 752.4 & 15.5 \\ 855.0 & 13.0 \\ \subseteq 32.4 & 12.7 \\ 1040.4 & 12.2 \\ 1112.4 & 12.0 \\ 1229.4 & 11.7 \\ 1292.4 & 11.6 \\ 1472.4 & 11.2\end{array}$

Heat Capacity (Ref. A-15):

Temperature $\left({ }^{\circ} \mathrm{F}\right)$ Heat Capacity $\left(\mathrm{Btu} / 1 \mathrm{~b}^{\circ} \mathrm{F}\right)$

$\begin{array}{rl}122 & 0.111 \\ 302 & 0.122 \\ 482 & 0.129 \\ 662 & 0.138 \\ 842 & 0.150 \\ 1022 & 0.167 \\ 1202 & 0.195 \\ 1364 & 0.241\end{array}$


Emissivity (Ref. A-15):

Temperature $\left({ }^{\circ} \mathrm{F}\right)$ Emissivity

$\begin{array}{rlll}700.0 & & & 0.855 \\ 901.4 & , & 0.900 \\ 1101.2 & \ddots & 0.925 \\ 1301.0 & & 0.925 \\ 1500.8 & & 0.885\end{array}$

\section{A.3.3 Air (at l atm.)}

Density (Ref. A-15): $0.081 \mathrm{lb} / \mathrm{ft}^{3}$

Therillat Cunductivity (Ref. A-15):

Temperature $\left({ }^{\circ} \mathrm{F}\right)$ Conductivity $\left(\mathrm{Btu} / \mathrm{hrft}^{\circ} \mathrm{F}\right)$

$\begin{array}{rl}80 & 0.0151 \\ 152 & 0.0168 \\ 260 & 0.0191 \\ 314 & 0.0202 \\ 440 & 0.0228 \\ 620 & 0.0263 \\ 800 & 0.0296 \\ 980 & 0.0329 \\ 1160 & 0.0361 \\ 1340 & 0.0388 \\ 1520 & 0.0414 \\ 1700 & 0.0439\end{array}$

Heat Capacity (Ref. A-15):

Temperature ( $\left.{ }^{\circ} \mathrm{F}\right)$ Heat Capacity (Btu/16 $\left.{ }^{\circ} \mathrm{F}\right)$

$\begin{array}{rr}80 & 0.243 \\ \therefore \quad 152 & 0.244 \\ 260 & 0.245 \\ 314 & 0.245 \\ 440 & 0.248 \\ 620 & 0.251 \\ 800 & 0.254\end{array}$


Temperature $\left({ }^{\circ} \mathrm{F}\right)$ Heat Capacity $\left(\mathrm{Btu} / 1 \mathrm{~b}^{\circ} \mathrm{F}\right)$

$\begin{array}{rr}980 & .257 \\ 1160 & .260 \\ 1340 & .263 \\ 1520 & .266 \\ 1700 & .269\end{array}$

A.3.4 Helium (at I atm.)

Density (Ref. A-15): $0.011 \mathrm{1b} / \mathrm{ft}^{3}$

Thermal Conductivity (Réf. A-15):

Temperature $\left({ }^{\circ} \mathrm{F}\right)$. Conductivity $\left(\mathrm{Btu} / \mathrm{hrft}^{\circ} \mathrm{F}\right)$

$\begin{array}{ll}80 & 0.0866\end{array}$

$152 \quad 0.0935$

$2600 \quad 0.103 \%$

$314 \quad 0.1087$

$440 \quad 0.1221$

$620 \quad 0.143$

$800 \quad 0.161$

$980 \quad 0.177$

11600.194

$1340 \quad 0.210$

$1620 \quad 0.225$

$1700 \quad 0.240$

Heat Capacity (Ref. A-15):

Temperature $\left({ }^{\circ} \mathrm{F}\right)$ Heat Capacity $\left(\mathrm{Btu} / \mathrm{lb^{ \circ } \mathrm { F } )}\right.$

80

$\cdot 152$

260

$\therefore \quad 314$

440

620

800

980

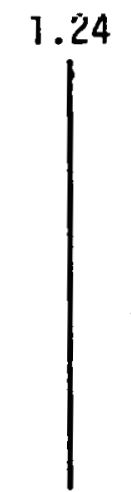


Temperature $\left({ }^{\circ} \mathrm{F}\right)$ Heat Capacity $\left(\mathrm{Btu} / 1 \mathrm{~b}^{\circ} \mathrm{F}\right)$

1160

1.24

1340

1520

1700

\section{A.3.5 Plug (Concrete)}

Bulk Density (Ref. A-17): $138 \mathrm{lb} / \mathrm{ft}^{3}$.

Thermal Conductivity (Ref. A-17): $0.58 \mathrm{Btu} / \mathrm{hr} \mathrm{ft}{ }^{\circ} \mathrm{F}$

Specific Heat (Ref. A-17): $0.2 \mathrm{Btu} / 1 \mathrm{~b}^{\circ} \mathrm{F}$

\section{REFERENCES}

A-1. Private communication with Mr. Bill Pechin of OWI.

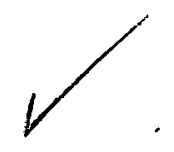

A-2. W. J. Mecham, W. B. Seafeldt and M. J. Steindler, "An Analysis of Factors Influencing the Reliability of Retrievable Storage Canisters for Containment of Solid High-Level Radioactive Waste", ANL-76-82, Argonne National Laboratory, August 1976.

A-3. Private communication with Mr. Steven Slate of Battelle-Pacific Northwest Laboratory.

A-4. "Quarterly Progress Report, Research and Development Activities, Waste Fixation Program, JuTy Through September 1975", BattellePacific Northwest Laboratories, BNWL-1949, January 1976.

A-5. J. E. Mendel and J. L. McETroy, "Waste Solidification Program, Vol. 10, Evaluation of Solidified Waste Products", BNWL-1666, July 1972.

A-6. J. R. Berreth, et. al., "Stabilization of Solidified High-Level Radioactive Wastes", Nuclear Technology, January 1977.

A-7. J. J. Cohen, et. al., "Determination of Performance Criteria for High-Level Solidified Nuclear Waste", NUREG-0279, Lawrence Livermore. Laboratory, Published July 1977.

A-8. R. D." Cheverton and W. D. Turner, "Thermal Analysis of the Radioactive Waste Repository, Progress Through June 1971", ORNL-4726, Oak Ridge National Laboratory, December 1971 (page.50). 
A-9. Francis Birch and Harry Clark, "The Thermal Conductivity of Rocks and its Dependence Upon Temperature and Composition", Am. Jour. Sc., Vol. 238, No. 8, August 1940 (page 534).

A-10. "Project Salt Vault: A Demonstration of the Disposal of High Activity Solidified Wastes in Underground Salt Mines", ORNL-4555, Oak Ridge National Laboratory, April 1971.

A-11. Gloria Viloria and S. M. Farouq Ali, "Rock Thermal Conductivity and its Variation with Density, Temperature and Fluid Saturation", Producer's Monthly, August 1968.

A-12. E. L. Walsh and E. A. Bathke, "Thermal Calculations in Shale, Y/OWI/SUB-76/16502, Kaman Sciences Corp., 28 September 1976.

A-13. S. P. Clark, Jr., Ed., "Handbook of Physical Constraints", GeoTogic Society of Amcrica, New York, 1866.

A-14. R. D. Cheverton and w. D. Turner, "Thermal Analys is of the National Radioactive Waste Repository: Progress Through March 1972", ORNL-4789, Oak Ridge National Laboratory, September 1972.

A-15. "Thermophysical Properties of Matter"., Thermophysical Properties Research Center.

A-16. Private Communication with $\mathrm{Mr}$. Glen Jenks of OWI.

A-17. "The Selection and Evaluation of Thermal Criteria for a Geologic Waste Isolation Facility in Salt", Y/OWI/SUB-76/07220, Science Applications, Inc., September 1976. 


\section{APPENDIX B \\ BIBLIOGRAPHY}

\section{ALLIED-GENERAL NUCLEAR SERVICES}

"Draft Supplement No. 1 to the Final Environmental Statement Related to Construction and Operation of Barnwell Nuclear Fuel Plant", NUREG-0082 Supp. 1 (Draft), Allied-General Nuclear Services, Barnwel1, S.C., June 1976.

R.J. Cholister, W.A. Rodger, R.L. Frendberg, W.L. Godfrey, W. Knox, W.B. Summer, "Nuclear Fuel Cycle Closure Alternatives", Allied-General Nuclear Services, Barnwell, S.C., April 1976.

R.J. Cholister, W.A. Rodger, R.L. Frendberg, W.L. Godfrey, W. Knox, W.B. Summer, "Nuclear Fuel Cycle Closure Alternatives, Appendix", Allied-General Nuclear Services, Barnwell, S.C., April 1976.

THE AMERICAN ASSOCIATION OF PETROLCUM GEOLOGISTS

J.E. Galley, ed., Subsurface Disposal in Geologic Basins - A Study of Reservoir Strata, The American Association of Petroleum Geologists, Tulsa, Oka., 1968.

\section{AMERICAN CHEMICAL SOCIETY}

A.M. Friedman, ed., Actinides in the Environment, American Chemical Society, Washington, D.C., 1976.

AMERICAN NATIONAL STANDARDS INSTITUTE

American Institute of Chemical Engineers, ed., "Design Objectives for Highly Radioactive Solid Material Handling and Storage Facilities in a Reprocessing Plant", ANSI N305-1975, American National Standards Institute, New York, N.Y., 19 March 1975.

ARGONNE NATIONAL LABORATORY

M.J. Steindler, N.M. Levita, W.J. Mecham, W.B. Seefeldt, L.E. Trevorrow, T.J. Gerding, B.J. Kullen, D.S. Webster, L. Burris, "Chemical Engineering Division Waste Management Programs Quarterly Report April-June 1974", ANL-8134, Argonne National Laboratory, Argonne, I11., November 1974.

ATLANTIC RICHFIELD HANFORD COMPANY

J.R. LaRiviere, E.L. Moore, "Preliminary Canister Size Criteria for Commercial Solidified High-Level Waste", ARH-ST-151 UC-70, Atlantic Richfield Hanford Company, Richland, Wash.

J.S. Kounts, ed., "Atlantic Richfield Hanford Company Quarterly Report Technology Devclopment for Long-Term Management of Hanford High-Level Waste January 1976 Through March 1976", ARH-ST-132 C UC-70, AtIantic Richfield Hanford Company, Richland, Wash., June 1976; 
J.S. Kounts, ed., "Atlantic Richfield Hänford Company Quarterly Report Technology Development for Long-Term Management of Hanford High-Level Waste October 1975 Through December 1975", ARH-ST-132 B UC-70, Atlantic Richfield Hanford Company, Richland, Wash., March 1976.

E.Y. Lyon, ed., "Atlantic Richfield Hanford Company Quarterly Report Waste Management and Transportation Technology Development April 1975 Through June 1975", ARH-ST-110 D, Atlantic Richfield Hanford Company, Richland, Wash., September 1975.

M.J. Kupfer, W.J. Van Slyke, eds., "Atlantic Richfield Hanford Company Quarterly Report Waste Management and Transportation Technology Development January 1975 Through March 1975", ARH-ST-110 C UC-70, Atlantic Richfield Hanford Company, Richland, Wash., May 1975.

M.J. Kupfer, W.J. Van Slyke, eds., "Atlantic Richfield Hanford Company Quarterly Report Waste Management and Transportation Technology Development Octuber 1974 Thruugh December 1974", ARH. ST-110 B UC-70, At lantic Richfield Hanford Company, Richland, Wash., Febritary 7.75.

H.P. Shaw, "Hanford Waste Management Program", ARH..SA.206, Atlantic Richfield Hanford Company, Richland, Wash., 1 Novembe: 1974.

\section{U.S. ATOMIC ENERGY COMMISSION}

"Environmental Statement Management of Commercial High-Level and Transuranium-Contaminated Radioactive Waste", WASH-1539, U.S. Atomic Energy Commission, September 1974.

"High-Level Radioactive Waste Management Alternatives", WASH-1297, U.S. Atomic Energy Commission, May 1974.

"Environmental Survey of Transportation of Radioactive Materials to and From Nuclear Power Plants", WASH-1238, U.S. Atomic Energy Commission Directorate of Regulatory Standards, December 1972.

W.G. Pierce, E.I. Rich, "Summary of Rock Salt Deposits in the U.S. as Possible Storage Sites for Radioactive Waste Materials", Geological Survey Bulletin 1148, U.S. Atomic Energy Commission, 1962.

\section{BATTELLE PACIFIC NORTHWEST LABORATORIES}

H.C. Burkholder, M.O. Cloninger, "The Reconcentration Phenomenon of Radionuclear Chain Migration", BNWL-SA-5786, Battelle Pacific Northwest

Laboratories, Richland, Wash., Rev. April 1977.

H.T. Blair, "Vitrification of Nuclear Waste Calcines by In-Can Melting", BNWL-2061- $\forall C-70$, Battelle Pacific Northwest Laboratories, Richland, Wash. May 1976.

R.P. Turcotte, "Radiation Effects in Solidified High-Level Wastes Part 2 Helium Behavior", BNWL-2051 UC-70, Battelle Pacific Northwest Laboratories, Richland, Wash., May 1976. 
J.L. MCElroy, "Quari:z:" Progress Report Research and Development Activities Waste Fixation Prog: win Jisuary Through March 1976", BNWL-2070 UC-70, Battelle Pacific Nortide: Laboratories, Richland, Wash.

J.L. McElroy, "Quarterly Progress Report Research and Development Activities Waste Fixation Program October Through December 1975", BNWL-1994 UC-70, Battelle Pacific Northwest Laboratories, Richland, Wash., April 1976.

J.E. Mende], W.A. Ross, F.P. Roberts, R.P. Turcotte, Y.B. Katayama, J.H. Westsik, Jr., "Thermal and Radiation Effects on Borosilicate Waste Glasses", BNWL-SA-5534, Battelle Pacific Northwest Laboratories, Richland, Wash., March 1976.

J.L. McElroy, "Quarterly Progress Report, Research and Development Activities Waste Fixation Program July Through September 1975", BNWL-1949, Battelle Pacific Northwest Laboratories, Richland, Wash., January 1976.

T.H. Smith, P.J. Pelto, D.L. Stevens, G.D. Seybold, W.L. Purcell, L.V. Kimmel, "A Risk-Based Fault Tree Analysis Method for Identification, Preliminary Evaluation, and Screening of Potential Accidental ReTease Sequences in Nuclear Fuel Cycle Operatinns", BNWL-1959 UC-70, Battelle Pacific Northwest Laboratories, Rich:an: !tash. January 19?6.

F.P. Roberts, G.H. Jenks, C.D. Bopp, "Radiation Effects in Solidified High-Level Waste Part I, Stored Energy", BNWL-1944, Battelle Pacific Northwest Laboratories, Richland, Wash., January 1976.

H.C. Burkholder, M.0. Cloninger, D.A. Baker, G. Jansen, "Incentives for Partitioning High-Level Waste", BNWL-192.7 UC-70, Battelle Pacific Northwest Laboratories, Richland, Wash., November 1975.

J.L. McElroy, J.E. Mendel, W.A. Ross, "The Expected Behavior of HLW Glass in Storage", BNWL-SA-5581, Batelle Pacific Northwest Laboratories, Richland, Wash., October 1975.

T.H. Smith, W.A. Ross, "Impact Testing of Vitreous Simulated High-Level Waste in Canisters", BNWL-1903 UC-70, Battelle Pacific Northwest Laboratories, Richland, Wash., May 1975.

K.J. Schneider, "Quarterly Progress Report Studies on Management of Selected Wastes April Through June 1974, BNWL-1843 UC-70, Battelle Pacific Northwest Laboratories, Richland, Wash., July 1974.

K.J. Schneider, A.M. Platt, eds., "High-Level Radioactive Waste Management Alternatives, Sections 1,2 and 3", BNWL-1900 Volume 1, Battelle Pacific Northwest.Laboratories, Richland, Wash., May 1974.

K.J. Schneïder, A.M. Platt, eds., "High-Level Radioactive Waste Management Alternatives, Section 4: Geologic Disposal", BNWL-1900 Volume 2, Battelle Pacific Northwest Laboratories, Richland, Wash., May 1974. 
X.J. Schneider, A.M. Platt, eds., "High-Level Radioactive Waste Management A. Ternatives, Sections 5, 6", BNWL-1900 Volume 3, Battelle Pacific Northwest Laboratories, Richland, Wash., May 1974.

K.J. Schneider, A.M. Platt, eds, "High-Level Radioactive Waste Management Alternatives, Sections 7, 8, 9", BNWL-1900 Volume 4, Battelle Pacific Northwest Laboratories, Richland, Wash., May 1974.

\section{BROOKHAVEN NATIONAL LABORATORY}

P. Colombo, W. Becker, R. Neilson, B. Nine, J. Pruzansky, "Savannah River Laboratory Long-Term Waste Storage Program Progress Report No. 9 JanuaryMarch 1975", BNL 20032, Brookhaven National Laboratory, Upton, N.Y.

P. Colombo, W. Becker, R. Neilson, B. Nine, J. Pruzansky, "Development of Durable Long-Term Radioactive Waste Composite Materials Progress Report No. 10 January-March 1975", BNL 20009, Brookhaven National Laboratory, Upton, N.Y., April 1975.

P. Colombo, W. Becker, R. Neilson, B. Nine, J. Pruzansky, "Tritium Storag". Development Progress Report No. 3 January-March 1975", BNL 19981 , Brookhaven National Laboratory, Upton, N.Y., April 1975.

\section{ELECTRIC POWER RESEARCH INSTITUTE}

G.J. Dau, R.F. Williams, "Status of Commercial Nuclear High-Level Waste Disposal", EPRI NP-44-SR, Electric Power Research Institute, Palo Alto, Ca., September 1976.

C.L. Comar, W.B. Seefeldt, W.J. Mecham, M.J. Steindler, B.L. Cohen, G. Howells, J.N. Stannard, "Plutonium: Facts and Inferences", EPRI EA-43SR, Electric Power Research Institute, Palo Alto, Ca., August 1976.

\section{U.S. ENERGY RESEARCH AND DEVELOPMENT ADMINISTRATION}

H.K. van Pollen, A.A. Ishteiwy, R.E. Chancellor, "Massive Hydraulic Fracturing Well Federal No. 498-4-1 Rio Blanco County, Colorado Final Report", Rio Blanco Natural Gas Company, Denver, Colo., April 1977.

M.E. Wacks, R.G. Post, "Proceedings of the Symposium on Waste Management Tucson, Arizona October 3-6, 1976", CONF-761020 UC-70, The University of Arizona, October 1976.

"Proceedings of the Workshop on Environmental Research for Transuranic Elements, November 12-14, 1975", Battelle Seattle Research Center, Seattle, Washington, ERDA-76/134, ERDA/Division of Biomedical and Environmental Research.

"Proceedings of the Conference on Decontamination and Decommissioning (D\&D) of ERDA Facilities, Idaho Falls, Idaho, August 19-21, 1975", CONF-750827, ERDA/Aerojet Nuclear Company, September 1975. 
"Alternatives for Managing Wastes From Reactors and Post-Fission Operations in the LWR Fuel Cycle", ERDA-76-43, Volume 1, ERDA, May 1976.

"Alternatives for Managing Wastes From Reactors and Post-Fission Operations in the LWR Fuel Cycle", ERDA-76-43, Volume 2, ERDA, May 1976.

"Alternatives for Managing Wastes From Reactors and Post-Fission Operations in the LWR Fuel Cycle", ERDA-76-43, Volume 3, ERDA, May 1976.

"Alternatives for Managing Wastes From Reactors and Post-Fission Operations in the LWR Fuel Cycle", ERDA-76-43, Volume 4, ERDA, May 1976.

"Aiternatives for Managing Wastes From Reactors and Post-Fission Operations in the LWR Fuel Cycle", ERDA-76-43, Volume 5, ERDA, May 1976.

\section{U.S. ENVIRONMENTAL PROTECTION AGENCY}

K. Anderson, et. al., "Decision-Makers Guide in Solid Waste Management", SW-500, Office of Solid Waste Management Programs, U.S. Environmental Protection. Agency, 1976.

"Environmental Radiation Dose Commitment: An Application to the Nuclear

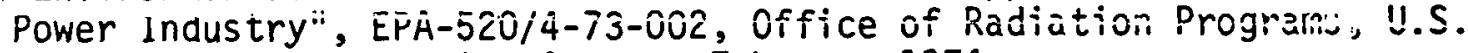
Environmental Protection Agency, February 1974.

"Environmental Analysis of the Uranium Fuel Cycle Part III Nuclear Fuel Reprocessing", EPA-520/9-73-003-D, Office of Radiation Programs, U.S. Environmental Protection Agency, October 1973.

FEDERAL ENERGY RESOURCES COUNCIL

"Management of Commercial Radioactive Nuclear Wastes A Status Report", Federal Energy Resources Council, 10 May 1976.

KAMAN SCIENCES CORPORATION

E.L. Walsh, E.A. Bathke, "Thermal Calculations in Shale", Y/OWI/SUB-76/ 16502, Kaman Sciences Corporation, Colorado Springs, Colo., 28 September 1976.

\section{LAWRENCE LIVERMORE LABORATORY}

J.J. Cohen, et. al., "Determination of Performance Criteria for HighLevel Solidified Nuclear Waste", NUREG-0279, Lawrence Livermore Laboratory, Livermore, Ca., July 1977.

J.R. Gaskil11, R.D. Taylor, "An Improved Shipping Container for Fissile Material", TID-4500 UC-41 (UCRL-14903 Rev. 1), Lawrence Radiation Laboratory, Livermore, Ca., 24 July 1968. 


\section{LOS AL.AMOS SCIENTIFIC LABORATORY}

Solid Waste Mangement Staff, "Quarterly Report Transuranic Solid Waste Management Research Programs April-June 1974", LA-5762-PR UC-70, Los Alamos Scientific Laboratory, Los Alamos, N.M., October 1974.

H-Division Staff, "Guidelines for the Interim Storage of AEC-Generated Solid Transuranic Wastes", LA-5645 UC-70, Los Alamos Scientific Laboratory, Los Alamos, N.M., June 1974.

\section{NATIONAL ACADEMY OF SCIENCES}

"An Evaluation of the Concept of Storing Radioactive Wastes in Bedrock Below the Savannah River Plant Site", Report by the Committee on Radioactive Waste Management, National Academy of Sciences, Washington, D.C., 1972.

"Disposal of Solid Radioactive Wastes in Bedded Salt Deposits", TID-25576, Report by the Committee on Radioactive Waste Management, National Academy of Sciences, Washington, D.C., November 1970.

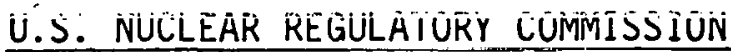

W.P. Bishop, F.J. Miraglia, Jr., eds., "Environmental Survey of the Reprocessing and Waste Management Portions of the LWR Fuel Cycle", NUREG0116 (Supp. 1 to WASH-1248), Office of Nuclear Material Safety and Safeguards, U.S. Nuclear Regulatory Commission, Washington, D.C., October 1976.

"Proposed Goals for Nuclear Waste Management - DRAFT", Division of Fuel Cycle and Material Safety, U.S. Nuclear Regulatory Commission, Washington, D.C., October 1976.

"Final Generic Environmental Statement on the Use of Recycle Plutonium in Mixed Oxide Fuel in Light Water Cooled Reactors, Health, Safety and Environment", Volume 1, Summary, NUREG-0002, Vol. 1, Office of Nuclear Material Safety and Safeguards, U.S. Nuclear Regulatory Commission, Washington, D.C., August 1976.

"Final Generic Environmental Statement on the Use of Recycle Plutonium in Mixed Oxide Fuel in Light Water Cooled Reactors, Heal th, Safety and Environment", Volume 2, NUREG-0002, Vol. 2, Office of Nuclear Materia] Safety and Safeguards, U.S. Nuclear Regulatory Commission, Washington, D.C., August 1976.

"Final Generic Environmental Statement on the Use of Recycle. Plutonium in Mixed Oxide Fuel in Light Water Cooled Reactors, Health, Safety and Environment:", Volume 3, NUREG-0002, Vol. 3, Office of Nuclear Material Safety and Safeguards, U.S. Nuclear Regulatory Commission, Washington, D.C., August 1976. 
"Final Generic Environmental Statement on the Use of Recycis Pl:itonium in Mixed Oxide Fuel in Light Water Cooled Reactors; Health, Safeijy and Environment", Volume 4, NUREG-0002, Vol 4, Office of Nucleur Mitieirial Safety and Safeguards, U.S. Nuclear Regulatory Commission, Washington, D.C., August 1976.

"Final Generic Environmental Statement on the Use of Recycle Plutonium in Mixed Oxide Fuel in Light Water Cooled Reactors, Health, Safety and Environment", Volume 5 Public Comments and Nuclear Regulatory Commission Responses, NUREG-0002, Vol. 5, Office of Nuclear Material Safety and Safeguards, U.S. Nuclear Regulatory Commission, Washington, D.C., August 1976.

"Final Generic Environmental Statement on the Use of Recycle Plutonium in Mixed Oxide Fuel in Light Water Cooled Reactors, Health, Safety and Environment", NUREG-0002, ES, Executive Summary, Office of Nuclear Material Safety and Safeguards, U.S. Nuclear Regulatory Commission, Washington, D.C., August 1976.

"Proceedings of the Conference on The Management of Radioactive Waste: Waste Partitioning as an Alternative 8-10 June 1976", Battelle-Seattle Research Center, NR-CONF-001, U.S. Nuclear Regulatory Commission, Wushingtun, i.t.

"Alternative Process for Managing Existing Commercial High-Level Radioactive Wastes", NUREG-0043, Battelle Pacific Northwest Laboratory for U.S. Nuclear Regulatory Commission, Washington, D.C., April 1976.

"Environmental Survey of Transportation of Radioactive Materials to and From Nuclear Power Plants", NUREG-75/038 (Supp. 1 to WASH-1238), U.S. Nuclear Regulatory Commission, Washington, D.C., April 1975.

"Statement of Saul Levine, Director, Office of Nuclear Regulatory Research U.S. Nuclear Regulatory Commission, Authorizing Legislation FY 1978 Before the Subcommittee on Energy and the Environment".

\section{OAK RIDGE NATIONAL LABORATORY}

B.C. Finney, R.E. Blanco, R.C. Dahlman, G.S. Hill, F.G. Kitts, R.E. Moore, J.P. Mitherspoon, "Correlation of Radioactive Waste Treatment Costs and the Environmental Impact of Waste Effluents in the Nuclear Fuel Cycle-Reprocessing Light-Water Reactor Fuel", ORNL/NUREG/TM-6, Oak Ridge National Laboratory, Oak Ridge, Tenn., January 1977.

H.C. Claiborne, "Thermal Analysis of a Fuel Cladding Repository Pilot Plant in Salt", ORNL/TM-5221 UC-70, Oak Ridge National Laboratory, Oak Ridge, Tenn., April 1976.

G.H. Jenks," "Gamma-Radiation Effects in Geologic Formations of Interest in Waste Disposal: A Review and Analysis of Available Information and Suggestions for Additional Experimentation", ORNL-TM-4827 UC-70, Oak Ridge National Laboratory, Oak Ridge, Tenn., September 1975. 
J.O. Blomeke, C.W. Kee, J.P. Nichols, "Projections of Radioactive Wastes to be Generated by the U.S. Nuclear Power Industry", ORNL-TM-3965, Oak Ridge National Laboratory, Oak Ridge, Tenn., February 1974.

W.C. McClain, "Rock Deformations Resulting from Project Salt Vault", ORNL-TM-4381, Oak Ridge National Laboratory, Oak Ridge, Tenn., November 1973.

R.C. Dahlman, Y. Tanaka, "Ecological-Environmental Assessments Related to the Federal Repository", ORNL-TM-3619, Oak Ridge National Laboratory, Oak Ridge, Tenn., July 1973.

R.D. Cheverton, W.D. Turner, "Thermal Analys is of the National Radioactive Waste Repository: Progress Through March 1972", ORNL-4789 UC-70, Oak Ridge National Laboratory, Oak Ridge, Tenn., September 1972.

R.D. Cheverton, W.D. Turner, "Thermal Analys is of the National Radioactive Waste Repository: Progress Through June 1971", ORNL-4726, Uak Ridge National Laboratory, Oak Ridge, Tenn., December 1971.

R.L. Bradshaw, W.C. McClain, eds., "Project Salt Vault: A Demonstration of the Disposal of High-Activity Solidified Wastes in Underaround Salt Mines", ORNL-4555 UC-70, Oak Ridge National Laboratory, Oak Ridge, Tenn., April 197i.

\section{OFFICE OF WASTE ISOLATION}

"National Waste Terminal Storage Program Information Meeting Volume I 7-8 December 1976", Y/OWI/TM-11/1, Office of Waste Isolation, Oak Ridge, Tenn., 6 December 1976.

PARSONS BRINCKERHOFF QUADE \& DOUGLAS, INC.

"Thermal Guidelines for a Repository in Bedrock", Y/OWI/SUB-76/16504, Parsons Brinckerhoff Quade \& Douglas, Inc., New York for Office of Waste Isolation, September 1976.

$\mathrm{RE} / \mathrm{SPEC}$, INC.

G.D. Callahan, J.L. Ratigan, J.E. Russell, A.F. Fossum, "Heat Transfer Analys is of the Waste-Container STeeve/Salt Configuration", ORNL-Sub4269-7, RE/SPEC, Inc., Rapid City, S.D. (RSI-0023) for Oak Ridge National Laboratory, Office of Waste Isolation, Oak Ridge, Tenn., 31 March 1971.

SCIENCE APPLICATIONS, INC.

"The Selection and Evaluation of Thermal Criteria for a Geologic Waste Isolation Facility in Salt", Y/OWI/SUB-76/07220, Science Applications, Inc., Oak Ridge, Tenn., September 1976. 


\section{UNION CARBIDE.}

D.W. Turner, "Considerations in the Selection of a High-Level Waste Canister", K-OP-217, Union Carbide, Oak Ridge, Tenn., 29 September 1976.

"Fourth Proceedings of the International Symposium on Packaging and Transportation of Radioactive Materials 22-27 September 1974 Miami Beach, Fla., CONF-740901-P1, Union Carbide Corporation Nuclear Division/U.S. Atomic Energy Commission.

"Proceedings of the Second International Symposium on Packaging and Transportation of Radioactive Materials 14-18 October 1968 Gatlinburg, Tenn., CONF-681001, Union Carbide Corporation/U.S. Atomic Energy Commission.

THE UNION OF. CONCERNED SCIENTISTS

"A Survey of the Public Health, Environmental, and National Security Effects uf Nuclear Power, Reviscd Edition", The Nurlear Fuel Cycle. The Union of Concerned Scientists, 1975. 
APPENDIX C. FIN MODELING VERIFICATION

As described in Section 2.2.5 of this report, the inherent limitations of the two-dimensional, $R-Z$ thermal model which was used to simulate the canister and repository required that the waste and fins be 'homogenized' in order that they also be represented in two-dimensional, $R-Z$ coordinates. Homogenizing the fin/glass combination thus eliminated the variable, $\theta$, and was performed by calculating an effective thermal conductance representing parallel heat flow through the fins and glass. The results given in Section 3 of this report-are based on this approach. Subsequently, a typical canister, with fins, was modeled and the results were compared with the homogenized results in order to verify this approach.

Because of geometrical symmetry, the eight-fin canister design can be divided into sixteen, pre-shaped segments. When the medium into which the canister is placed is uniform. as when the canister is standing vertically in air, the temperatire in any one segment will be identical to the temperaiures in any other segment. Figure $C-1$ shows one possible segment geometry. The segment is bounded by one half of a fin, a plane cut through the waste halfway between fins, and the surface of the canister. The sides of the segment are adiabatic surfaces, thus all heat flows radially outward from the centerline. As shown in Figure $C-1$, the fin and the waste between the radi $i$ of the inner and outer ends of the fin are divided into eight radial sections. Each waste radial section is further divided into four circumferential nodes. An outer ring of waste, outside of the fin, is also broken into four nodes which are connected to corresponding canister nodes. The center of the canister is modeled by one, pie-shaped node extending from the centerline to the fin tip. The thermal conductors connecting the nodes are all shown an Figure $c-1$. Note that the radial heat path through the fin and the circumferential path through the canister wall are both modeled. All waste nodes have internal heat generation which is dependent on the waste age since reprocessing.

A steädy-state solution was obtained for the two-dimensional model described, for conditions representative of interim storage in air. A 24-inch diameter canister was arbitrarily selected, and it was assumed to be stored in still air at $80^{\circ} \mathrm{F}$ and radiating to a surrounding medium also 


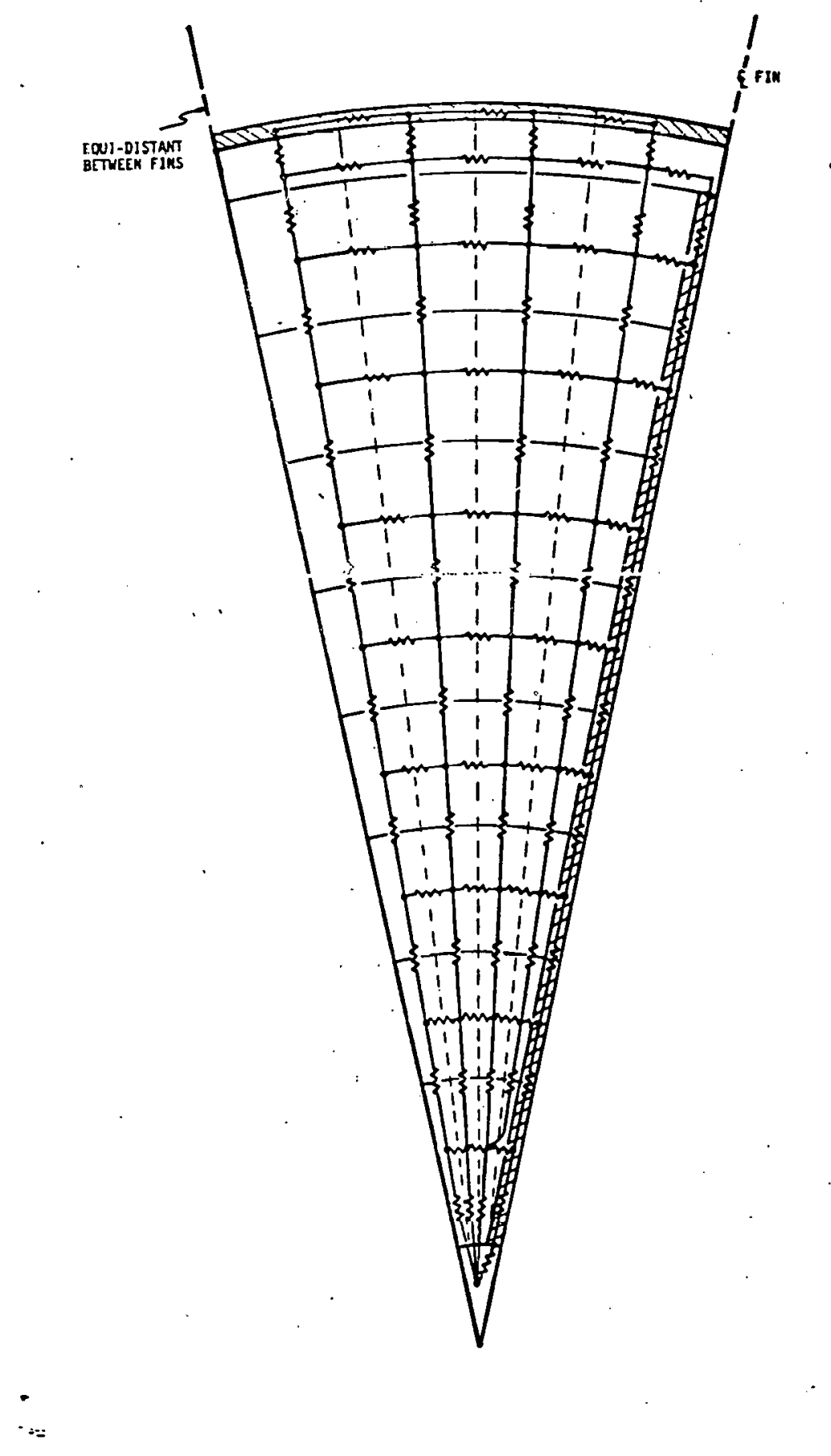




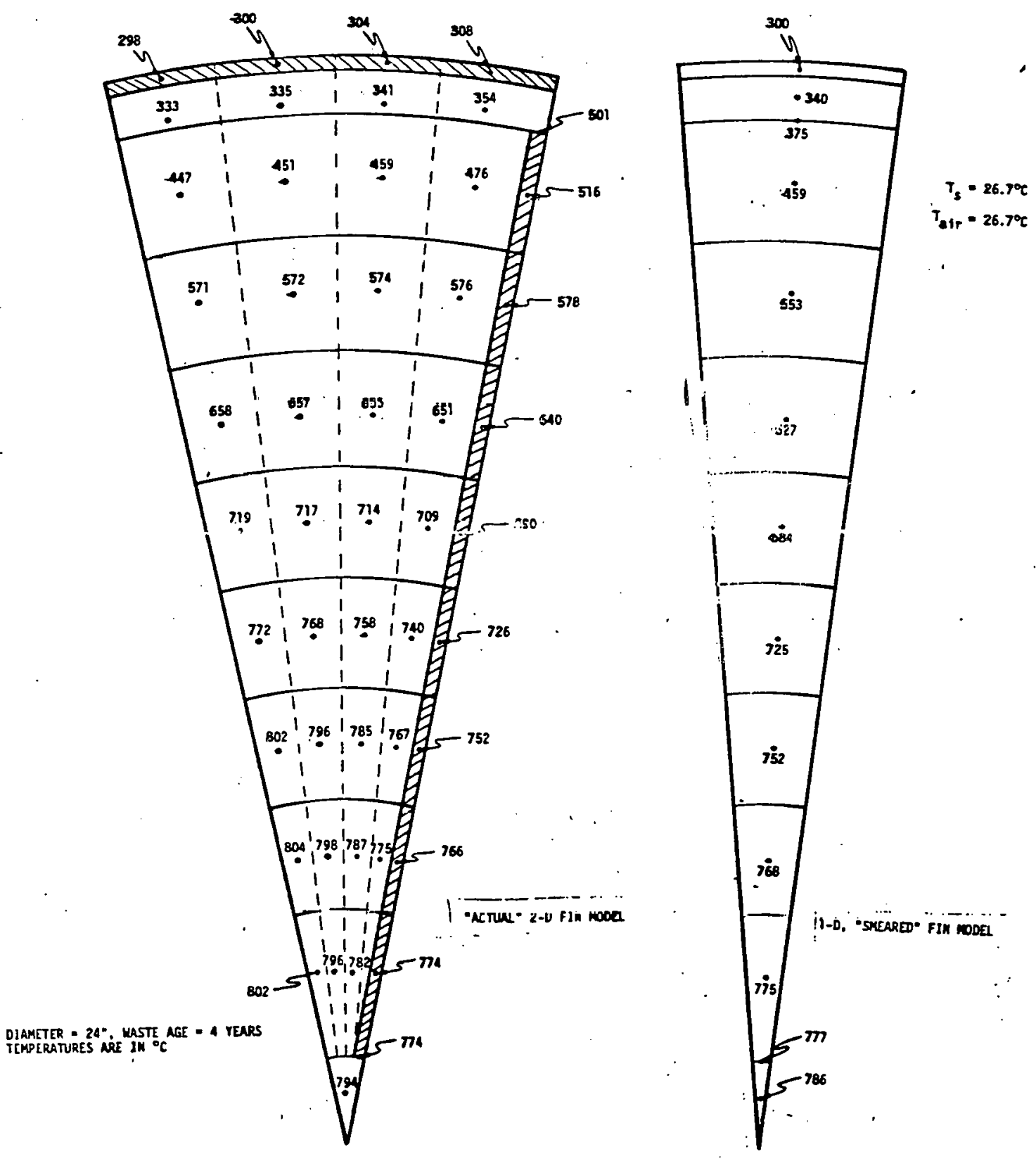


at $80^{\circ} \mathrm{F}$. The waste age was taken to be four years, which is the approximate age at which the constraint of $800^{\circ} \mathrm{C}$ waste was indicated by the onedimensional, homogenized model. Figure $\mathrm{C}-2$ shows the resulting temperatures for the two-dimensional solution with the homogenized, onedimensional solution alongside for comparison.

The centerline temperatures are seen to agree to within $8^{\circ} \mathrm{C}$. The average canister temperature from the two-dimensional model agrees to within $3^{\circ} \mathrm{C}$ with the results obtained from the one-dimensional model. Thus, the results agree to within one percent. Thus, assuming the results for a 24-inch canister to be representative, the homogenized approach is seen to provide a close approximation of the actual case. 